\title{
Fortalecimiento de la unión familiar desde el amor y la libertad en la comunidad de Ayahualulco, Veracruz.
}

\author{
Luis Alberto Galván Medina \\ María Guadalupe Vecino Navarrete
}

Asesora:

D.E. Esther Fragoso Fernández

\section{Introducción}

Esta investigación es acerca del "Fortalecimiento de la unión familiar desde el amor y la libertad en la comunidad de Ayahualulco, Veracruz".

El problema de investigación surge al pensar en los cambios de la globalización, tecnologización y modernización de la sociedad, pues ésta se ha convertido en una sociedad de consumismo y materialismo donde se crean nuevas necesidades como comenta Alfonso Eiré en el Diario "El País" (19 de Abril de 2009) que "...desde la infancia, los niños están aleccionados por la ideología dominante en el mercado de servicios y también las necesidades creadas por el consumismo", por lo tanto la jerarquía de valores se ha modificado, como establece Litzahaya en su ensayo "Los Valores" (Litzahaya Romero, 2000) que "Los valores están presentes desde los inicios de la humanidad. Para el ser humano siempre han existido cosas valiosas: la verdad, la belleza, la felicidad entre otras. Sin embargo, el criterio para darles valor ha variado a través de los tiempos. Se puede valorar de acuerdo con criterios estéticos, esquemas sociales, costumbres, principios, estudios etc. Los valores son producto de cambios y transformaciones a lo largo de la historia". Y actualmente se toman como más importantes los valores estéticos y hedonistas establecidos por la sociedad y el valor que se da a las cosas materiales.

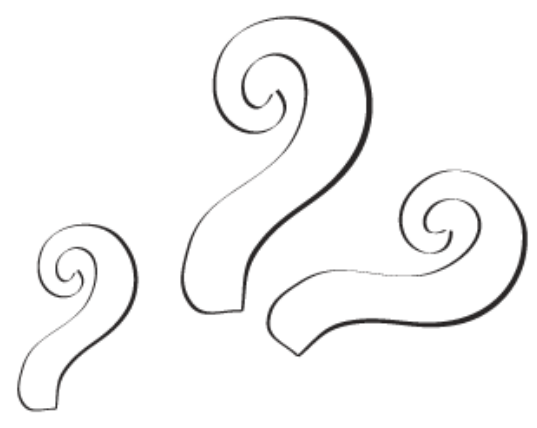

Preguntas de investigación:

¿Existe un fortalecimiento de unión familiar desde el amor y libertad en la comunidad de Ayahualulco, Veracruz?, iEs importante en esta comunidad retomar valores que fomenten el fortalecimiento de la unión familiar? y ¿Realmente la unión familiar en Ayahualulco, Veracruz está desprendida del amor y la libertad?

El objetivo de esta investigación es comprender el fenómeno de la unión familiar desde los valores como amor y libertad.

\section{Justificación.}

Esta investigación es trascendental ya que a consecuencia de la modernización que genera una cultura artificial, en la que los aspectos materiales y la tecnología sugieren una nueva forma de vida, se ha modificado la importancia de valores esenciales para la convivencia familiar y por lo tanto la familia en su totalidad, por esto es importante impulsar a las familias de la comunidad a fomentar valores para retomar la idea de unión familiar y convivencia óptima desde los valores. El beneficio social de esta investigación es que con la información e interacción que exista con las familias de Ayahualulco, Veracruz tomen conciencia del papel que tienen estos valores dentro del ámbito familiar y cómo éstos podrían mejorar la unión familiar dentro de esta institución. 


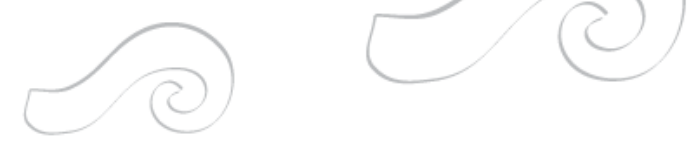

En el marco histórico se tocan temas como la familia antigua y una comparación con la familia y sociedad actual, cómo el hombre antiguo juega un papel esencial en el área laboral para la manutención de su familia y actualmente eso ha sido sustituido porque la familia ha cambiado su estructura como explica Engels en su libro "El origen de la familia, la propiedad privada y el estado" (2001, pág. 44), que más adelante se abordará.

En el marco conceptual se retoman nociones de los elementos clave como la familia, la unión de ella, la situación mexicana influida por la Norteamérica y los valores fundamentales desde los que es importante fomentar el fortalecimiento de la unión familiar como el amor y la libertad, así como los valores derivados y complementarios, también es primordial considerar que se explica la necesidad de retomar este fortalecimiento de la familia mediante los valores importantes ya mencionados. Se explica también la importancia de los derechos humanos en la familia y la educación de los mismos para la convivencia y su práctica en la familia, finalmente se explica el sentido y significado del fortalecimiento de la unión familiar desde los valores.

El marco teórico expone referentes relevantes a lo largo de la historia por lo que en él se retoman algunas teorías importantes que han dejado algún tipo de impacto sobre los temas fundamentales que en esta investigación se utilizan.

Finalmente en el marco referencial, se abordará la urgencia del proyecto PERLA el cual habla acerca de la educación en y desde el respeto a los derechos humanos, y retoma las investigaciones con los temas de la violencia de los derechos humanos y la democratización de la escuela, así como el respeto de estos derechos en todas las dimensiones de la persona y la sociedad.
En la metodología se retoma el enfoque de esta investigación que es el cualitativo ya que en primer lugar se acudirá a la comunidad de Ayahualulco, Veracruz, es decir, el campo natural, además el tema de esta investígación está referido a ciertos aspectos internos del ser los cuales pueden ser descritos cualitativamente, los alcances que se tienen en los cuales se buscan conocer y la vida de la comunidad para fortalecer la unión familiar desde los valores, por medio la impartición de talleres; amor y libertad. Los objetivos se integran en: investigar el fenómeno de la unión familiar desde los valores como amor y libertad en la comunidad de Ayahualulco, Veracruz e impartición de talleres; el contexto que es el lugar donde se realizará esta investigación y la población que formará parte de la muestra en la comunidad antes mencionada, así como también la hipótesis referida a la existencia de familias unidas en el lugar de la investigación, el procedimiento son las actividades realizadas durante dicha investigación y los instrumentos que serán aplicados en la visita que se realizará los cuales son: la entrevista semi-estructurada, la historia de vida y el diario de campo, así como la información que se brindará a través de los talleres mencionados.

\section{Marco Histórico}

En la época primitiva los núcleos familiares, se decían familiares porque estas personas eran parentescos, se desplazaban por los lugares conforme al clima o a la escasez de alimentos. La familia era la unidad económica ya que los hombres iban a cazar y sostenían a la esposa y a los hijos. Más tarde la familia tomó un carácter religioso pero en el siglo XVI pasó a un carácter civil. La familia era entendida como la responsable de asegurar la supervivencia de sus miembros y actualmente es entendida como un espacio de afecto, amor y comprensión, donde se procura el bienestar de sus miembros con características propias. 


\section{$\curvearrowright \curvearrowright \curvearrowright \curvearrowright \curvearrowright \curvearrowright \curvearrowright$}

Según Engels en su libro El origen de la familia, la propiedad privada y el estado (2001 pág.44) la familia ha evolucionado en diferentes etapas. La primera es la familia consanguínea en donde los grupos conyugales se clasificaban por generaciones. La segunda es la familia punalúa donde prohibían el matrimonio entre hermanos. Familia sindíasmica en donde se formaban matrimonios para un tiempo largo, el hombre tenía una mujer principal de entre las demás y viceversa. Finalmente la familia monogámica es destacada porque aquí se consolida la familia y los lazos del matrimonio son más fuertes.

Cuando el hombre se empieza a sentir en comunidad es cuando surgen los valores porque al sentirse en ésta se ve la necesidad de socializar con los demás, según Efraín Sigüenza en sus Lecturas de educación en valores (2004, pág. 2) y que "unas personas necesitamos de otras", entonces aquí surgen los valores para regular la relación entre unos y otros; todos los miembros contribuían para el progreso de su comunidad, las tareas y trabajos se realizaban sin pagos únicamente por respeto a los más viejos considerados comolos más sabios.

En la actualidad los apetitos del hombre buscan ser satisfechos, por lo que se ha convertido en esclavo de sus propias pasiones. Ahora no gobierna el más sabio, sino el poder que aplaca los excesos para lograr el orden y el respeto de los bienes terrenales antes mencionados. Por lo tanto la jerarquía de valores ha sido modificada a través del tiempo generando una cultura superficial, de consumismo e individualismo, dejando a un lado la unión familiar desde los valores como el amor y la libertad además de la participación, asertividad, justicia, compasión y humildad.

\section{Marco Conceptual}

El fortalecimiento es definido como las actividades de la construcción, reestruc- turación o crecimiento de una organización (www.cubanalisis.com/BIBLIOTECA $\% 20 \mathrm{ON}$ \%20LINE/DICCIONARIO \%20DEL \%20CAST RISMO \% 20COTIDIANO\%20ON\%20LINE/F. $\mathrm{htm}$. Recuperado el 27 de Febrero de 2009). Es decir que es, el desarrollo integral de la organización, a partir de actividades para fomentar un crecimiento y desarrollo óptimo; hablando particularmente de la familia, este fortalecimiento que conduce a hablar acerca de la unión familiar, ya que en estas actividades que se realizan, las familias llevan a una mejor convivencia y una unión que es importante para la ejecución de los valores.

"La familia es el medio necesario para conservar y transmitir valores culturales, educativos y formativos entre sus integrantes." (CNDH, 2003, pág. 5). Ya que es la base de la sociedad y es responsabilidad de los padres transmitir estos valores y así fomentar la unión en la familia para mejorar el desarrollo de quienes la integran.

Las familias estaban encargadas de enseñar los valores a sus integrantes. Según O. Oliveros en su obra Relaciones Humanas en la Familia (1999, pág. 104). "Decir que la familia es ámbito de valores significa destacarla como un lugar privilegiado para el cultivo de valores", pues el hogar es el lugar donde las personas aprenden la mayoría de sus comportamientos, actitudes, principios $y$ valores futuros.

En la actualidad la función de la familia se ha visto modificada por los cambios que ha sufrido la sociedad en el aspecto político, económico, cultural y religioso, entre otros. Lo que ha conducido a una complejidad y cambio en el sistema familiar, según la $\mathrm{CNDH}$ en el "Programa para el fortalecimiento de la familia" (2003, pág. 7), "Las mujeres, por razones económicas, se ven obligadas a salir de su hogar y encargar el cuidado de sus hijos", lo que ha originado la creación de una gran variedad de instituciones a las que se les han delegado automáticamente funciones 


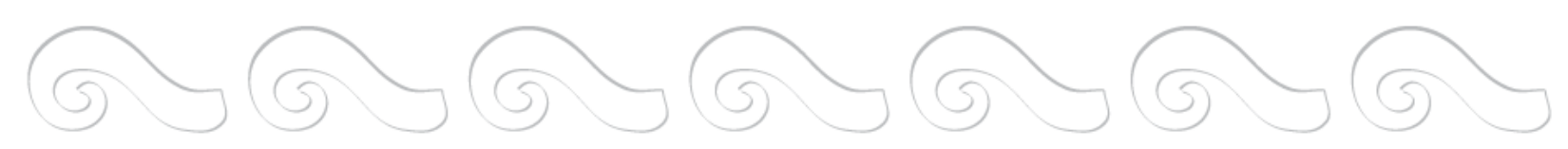

familiares. La escuela juega un papel importante, pues ahora apoya al desarrollo y fomento de los valores de los individuos.

En México existe una influencia norteamericana que ha producido una transculturación, la cual ha afectado directamente a la familia como núcleo social y que refleja la falta de valores en la sociedad, incrustando problemáticas actuales de otras índoles como agresión familiar, alcoholismo, drogadicción, apatía e indiferencia ante los valores, entre otras, las cuales dad la cercanía entre naciones y debido a los altos fenómenos como la migración han afectado directa e indirectamente.

Según Mariana Perillita Nava, en el ensayo Los valores y la juventud de hoy (2000, pág. 17). “Un valor es un don intrínseco del ser humano que puede hacer crecer mediante la preservación del mismo y que lo lleva a su perfeccionamiento". También un valor tiene una objetividad en el cual todos los seres humanos aprendemos, pero cada quien lleva estos valores de acuerdo a sus circunstancias y cada quien las mira desde diferente perspectiva.

Es importante definir los valores fundamentales para la unión familiar, ya que el reconocimiento de estos hará cumplir mejor el objetivo, según Ramón Tallabs estos son: amor y libertad además de participación, asertividad, justicia, compasión y humildad, valores que a continuación se definen.

Amor: "Es interesarse por alguien, querer estar cerca y compartir con él. Es un sentimiento especial que te llena el corazón. Amar a alguien significa tratarlo con mucho cuidado y bondad, porque te importa mucho. $\mathrm{El}$ amor se puede demostrar con una sonrisa, una manera agradable de hablar, un acto considerado o un abrazo. Amar es ponerse en el lugar del otro y preocuparse por lo que siente. Es aceptar a los demás tal como son. También se puede amar a los desconocidos, simplemente interesándote por lo que les sucede. Amar es tratar a otros tal como a ti te gustaría que te trataran: con atención y respeto" (Tallabs, Ramón, 2000, pág. 35). Es uno de los valores fundamentales en la unión familiar, pues de este se derivan muchos valores como la confianza, amistad, lealtad, fidelidad, convivencia, comunicación, cariño, afecto, empatía; ya que cuando se ama a una persona se le respeta, se le tiene confianza entre otras, cosas que se fomentan desde la familia. En la actualidad la familia está perdiendo estructura y por lo tanto se ha dado una pérdida de valores que han sido sustituidos por materialismo y el consumismo en donde las personas hacen de las cosas necesidades que realmente nolo son.

El amor es un valor fundamental en la familia, en ella se enseña a amar desde la infancia, de ello dependerá si en el futuro la persona es capaz de amarse a sí mismo y amar a otros; este promueve la unidad y comunicación, pues si amas a tu familia buscarás su felicidad y estarás más unida a ella.

La familia crece rodeada de aspectos externos e internos como los conflictos, lo importante es que con el amor, la libertad, la convivencia y otros valores se resuelvan estos conflictos en un ambiente sano y hacia un futuro exitoso de la formación en valores.

En conclusión el amor está en la vida que se comparte y se construye en una familia.

Libertad: "Es la capacidad que tenemos las personas para escoger entre una y otra cosa la mejor; lo mejor es todo aquello que te ayuda a crecer en tus capacidades, que te hacen ser mejor persona beneficiando a los demás; es por eso que cuando escogemos ser justos, compasivos y misericordiosos, estamos siendo libres, porque la libertad es para amar, para poder ser feliz amando y hacer felices a los demás" (Tallabs, Ramón, 2000, pág. 32). Este valor ayuda a aprender acerca de los propios errores y a crecer como personas, pero 


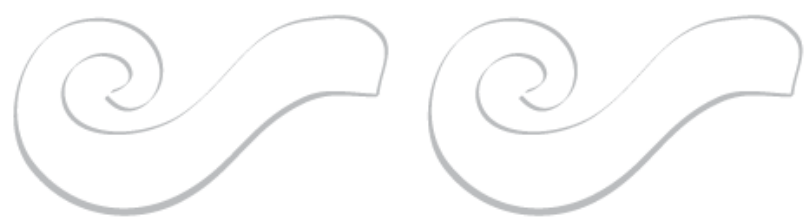

es importante saber elegir bien para tener buenos resultados.

La libertad es lo que permite decidir al hombre si algo es mejoro o no, si quiere o no hacer algo; en este sentido es muy importante porque de esta manera el hombre es libre, pero lo lleva a tener responsabilidad en sus actos, también cabe mencionar que la libertad es inherente al hombre y se sitúa en el interior de la persona con la inteligencia y voluntad.

Es importante que en la familia se practique una educación para la libertad ya que es necesario que cada miembro aprenda a decidir su libertad, ser autónomo y por lo tanto a enfrentar las consecuencias de sus actos.

Los valores antes mencionados se relacionan unos con otros ya que uno de ellos deriva en otros y así se va logrando la unión familiar.

Los valores poseen una objetividad por sí mismos, por ejemplo, la justicia es dar a cada quien lo que le corresponde, y este valor es igual en cualquier lugar por más recóndito que sea; pero como valor posee también una subjetividad que está determinada por las circunstancias o el contexto en el que se desarrolla.

El fortalecimiento de la unión familiar desde los valores se define como la realización de ciertas actividades ligadas a valores fundamentales para ésta, que llevarán a impulsar el fortalecimiento de la unión familiar en la comunidad de Ayahualulco para su mejor desarrollo.

\section{Marco Teórico}

Según Ramón Ortega Tallabs en su obra Crece: Valores para la vida (2000, pág. 16). “La familia es el lugar privilegiado para formar una afectividad equilibrada y sana, para crecer en amor y para trabajar con ánimo. Es una institución social encargada de reproducir el

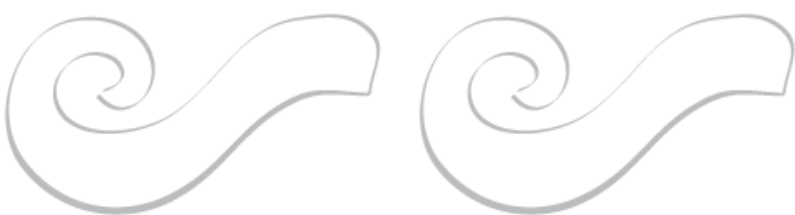

orden social y de asegurar la transmisión del patrimonio técnico-cultural a las sucesivas generaciones". En este grupo socializador primario se forjan una serie de valores $y$ virtudes que ayudan a sus elementos a relacionarse para ayudar a la formación personal afectiva y emocional en el desarrollo de su vida diaria con los que los rodean.

En la familia se transmiten los lazos que conducen a las nuevas generaciones a realizarse en el medio social, en valores, virtudes y en el desarrollo psico-emocional, y es así como se forma y transmite la cultura.

La familia es muy importante en la vida de los individuos ya que como grupo primario está encargado de transmitir la cultura la cual lleva implícita los valores; también estereotipan hábitos, costumbres y determinados parámetros, de esta manera el individuo se socializa; estos valores son inculcados de diversas formas de acuerdo a cada ámbito familiar en los aspectos subjetivos, interpersonales $\mathrm{y}$ sociales. La familia es dinámica, por lo tanto está en constante cambio lo que produce la diferente transmisión de los valores de generación en generación.

Litzahaya Romero Campos en el ensayo Los valores y la juventud de hoy (2000, pág. 22) dice que "Los valores son producto de cambio y transformaciones a lo largo de la historia, surgen con un especial significado y cambian o desaparecen en las distintas épocas". Como se mencionó anteriormente, es diferente la transmisión de los valores de generación en generación creando y transformando nuevos significados $y$ formas para estos.

Según O. Oliveros en su obra Relaciones Humanas en la Familia (1999, pág. 102) "Los valores son especificaciones del bien, y todos, naturalmente, tendemos al bien, pues nuestra voluntad tiende al bien". Y así el ser humano buscará la realización y superación para llegar a la perfección en todos los aspectos y satisfacer distintas necesidades. 


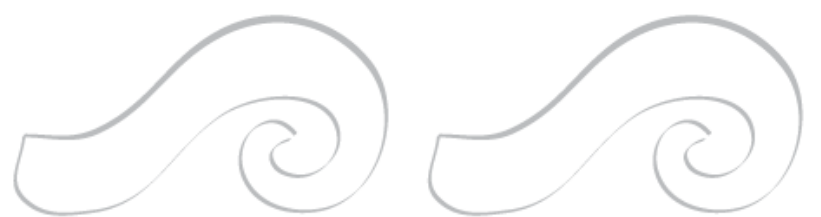

4. Marco Referencial

Para esta investigación se trabajará con el proyecto Educativo Regional Lasallista Latinoamericano (PERLA), en el cual se establecen las urgencias educativas más importantes para transformar el entorno formativo y social de los menos favorecidos así como una respuesta articuladora a estas urgencias, para el desarrollo del ministerio educativo lasallista en la región entre otras, desde la inspiración proveniente de Jesucristo; de esta manera se eligió una de estas urgencias para trabajar en la investigación que se llevará a cabo en la comunidad de Ayahualulco, Veracruz.

"Una educación en y desde el respeto a los derechos humanos".

Originar, defender y fortalecer el respeto a los derechos humanos engarzando programas, obras y acciones que hagan concientizar a las personas sobre las situaciones de las víctimas de abuso, explotación, violencia e injusticia. Enfocados en esta urgencia educativa del programa PERLA se realizará una investigación que permita a partir del fortalecimiento de la unión familiar y con apoyo de valores en ella como amor, participación, asertividad, justicia, compasión, humildad y libertad en la comunidad, se logre fomentar el respeto de los derechos humanos en la comunidad de Ayahualulco, Veracruz.

Por lo que en esta investigación de la unión familiar desde los valores, se tratará de evitar que ocurran sucesos de violencia principalmente dentro de la familia, ya que es uno de los principales agentes socializadores del individuo. Con lo que desde la escuela se buscará este cambio puesto que según Gruffat Carolina (2005) en Educación y sociedad "la escuela sigue siendo un espacio privilegiado de circulación y transmisión social" (http://portal.educ.ar/noticias/educacion-ysociedad/el-respeto-de-los-derechos- humanos/29/03/09/.29 de marzo de 2009) y se tomará este poder de la escuela para conseguir realizar los objetivos de la investigación de manera viable, confiable y segura, logrando con la oportunidad transformadora de la escuela realizar un cambio convertidor legal de la familia.

Gruffat Carolina (2005) en Educación y sociedad habla de que "la enseñanza de los derechos humanos no debe concebirse desde una materia puntual sino que debe atravesar todas las áreas", y "La Declaración Universal de los Derechos Humanos señala a la educación como un derecho fundamental, sus principios deben impregnar las políticas sociales"(http://portal.educ.ar/noticias/educa cion-y-sociedad/el-respeto-de-los-derechoshumanos/29/03/09/. 29 de marzo de 2009) . Esto también debe ser considerado puesto que en comunidades pequeñas como la de Ayahualulco, Veracruz, la educación es puesta en segundo plano, dado que para ellos es más importante llevar acabo otras labores como son las de trabajo, para ayudar a la economía familiar. Por lo que dentro del trabajo de campo, por medio de los valores, se promoverá el valor de la educación, lo que llevará a una mejor actitud ante la familia y la sociedad en general.

Cita Ascencio Anastasio (1995) en su investigación de Derechos Humanos y Educación que "por medio de la promoción, educación y defensa de los derechos humanos se propicia el desarrollo integral de los pueblos y realiza un esfuerzo que coadyuva en la consecución de una cultura de paz, democracia y respeto por los derechos fundamentales de todos los seres humanos" ( h t t p : // w w w. con g r e so.gob. pe/congresista/1995/avega/nota13.htm.29 de marzo de 2009). Por esto se sabe que con el fomento de los valores en la familia se podrá lograr un fortalecimiento puesto que con la democracia y el respeto implícito en ella, se logrará formar una conciencia dentro de la misma para su valoración como grupo. 


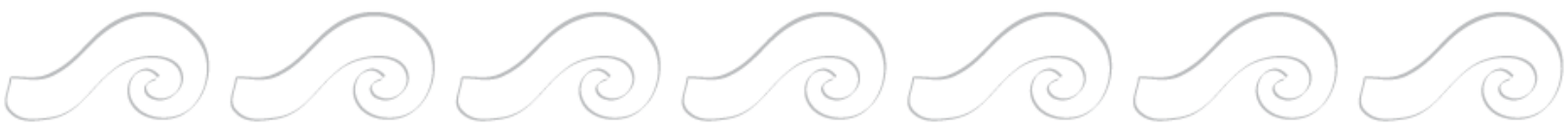

La importancia de la investigación tomando el papel de Universitarios representando el campo formativo de la educación, es en la que se darán a conocer los valores, para así lograr la formación y difusión de los derechos humanos en la familia, que es el principal agente socializador del estado.

En conclusión los valores en la familia han ido evolucionando a través del tiempo en forma paralela lo que ha traído consigo una modificación inminente de dichos valores y del concepto familiar contemporáneo que involucra el concepto de amor y libertad, esenciales para el óptimo desarrollo de la convivencia y así impulsar el fortalecimiento de la unión familiar.

\section{Metodología}

\section{Enfoque}

El enfoque a retomar es el de investigación cualitativa porque está dirigida hacia la exploración y comprensión de los valores en la familia y el fomento de los mismos para la unión familia, fenómeno que no es tangible, es decir, hacia características internas y sociales del ser. Estos se rigen por simbolismos que la misma sociedad ha establecido. Este enfoque también permite acudir al ambiente natural del fenómeno que es la comunidad de Ayahualulco en Veracruz, de esta manera se estudiará la totalidad; de tal forma que se vinculará la teoría y la práctica del fenómeno en la realidad dinámica.

En esta investigación el proceso es lo que más importa pues de esta manera se comprenderá mejor el fenómeno.

\section{Alcances}

Esta investigación es descriptiva ya que se conocerán las situaciones, alteraciones, costumbres y actitudes a través de un acercamiento a las actividades, objetos, procesos y personas de la comunidad de
Ayahualulco, orientados hacia el fortalecimiento de la unión familiar desde algunos valores, a través de entrevistas se conocerán las costumbres familiares para después comprenderlas trabajando con las personas y fomentar los valores con actividades que se realizarán durante la estancia en la comunidad.

\section{Objetivo General}

Investigar el fenómeno de la unión familiar desde los valores como amor y libertad.

\section{Objetivos específicos}

- Analizar la unión familiar.

- Observar los valores que se llevan a cabo en la familia.

- Fomentar otros valores importantes para la familia.

- Forjar la unión familiar desde los valores; amor y libertad.

\section{Contexto}

Según el Centro Nacional de Desarrollo Municipal, Gobierno del Estado de Veracruz (2000) Ayahualulco se localiza en la zona montañosa del centro de Veracruz, limita al norte con Perote, al noreste con Xico, al este con Ixhuacán de los Reyes y al sur con el Estado de Puebla. El Municipio se encuentra ubicado en la zona central y sobre la parte más alta y fragosa de la Sierra Madre Oriental.

La principal lengua indígena es el náhuatl. La educación básica es impartida por 20 planteles de preescolar, 26 de primaria y 4 de secundaria. Además cuenta con una institución que brinda el bachillerato.

\section{Población}

En la comunidad el trabajo con personas de todas las edades se enfoca a la familia en 

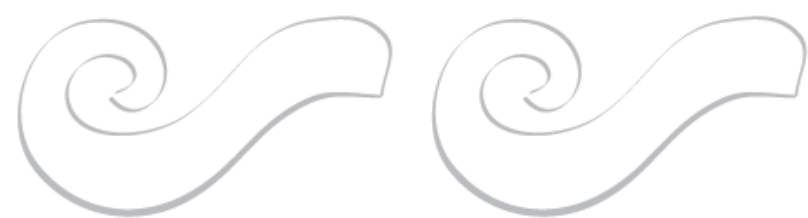

particular, ancianos, adultos y niños; entre ellos 20 menores de 15 años, 6 personas de 15 a 30,7 de 30 a 40 años y 16 mayores de 40; 30 mujeres y 19 hombres en total. Se indagará sobre su funcionamiento, roles, costumbres, situaciones, problemáticas y convivencia entre otras, es decir, se trabajará con ellas en campo a lo largo de una semana.

Se trabajará con diferentes familias para comprender y analizar el contexto y poder describir desde los valores la unión que existe; también fomentar estos valores importantes en la sociedad para fortalecer la unión familiar y así poder mejorar el contexto en esta comunidad para que funcione mejor.

\section{Hipótesis}

En la comunidad de Ayahualulco Veracruz existe una fuerte unión familiar desde los valores como: amor y libertad además de participación, asertividad, justicia, compasión y humildad los cuales fortalecen a la misma como base de la sociedad.

\section{Procedimiento}

1. Realización de la metodología de la investigación e instrumentos.

2. Visita de una semana a la comunidad de Ayahualulco Veracruz.

3. Análisis y comprensión del contexto, aplicación de instrumentos.

4. Obtención de los datos para nuestra investigación y su análisis, reporte graficado.

5. Impartición de talleres a padres de familia; amor y libertad.

6. Conclusiones de la investigación y su verificación.

7. Reflexión acerca de la experiencia obtenida al trabajar con estas personas.

8. Realización del informe de la investigación de acuerdo a los resultados obtenidos.

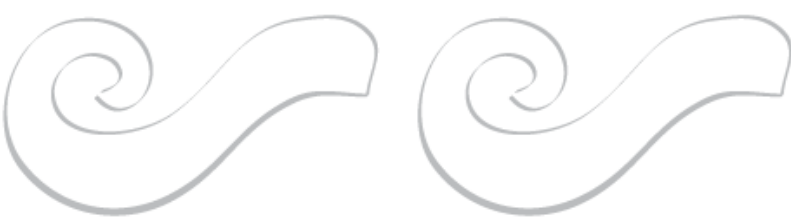

\section{Resultados}

En esta investigación se recabó información procedente de padres e hijos respectivamente, que fueron entrevistados $y$ encuestados acerca del tema de los valores en la familia, en las cuales las entrevistas y encuestas fueron acomodadas desde perspectivas teóricas para adaptarlas a sus condiciones. Para que con ellos se pudiera hacer una comparación y análisis de la relación de orden, en parentesco, en concordancia con la concepción que tienen las personas en esa comunidad acerca del tema mencionado; se obtuvieron los siguientes datos.

El 85\% de los padres e hijos concordaron que un valor es "Saber cómo no se portan" Lo cual nos indica que tanto padres como hijos tienen una concepción muy de acuerdo a la definición de valor, puesto que solo el 15 por ciento de las personas entrevistadas presentaron respuestas diferentes a las dadas por su familiar. En cuanto a lo que es la familia el $88 \%$ de las familias, padres como hijos coincidieron que es un "Espacio de afecto donde se lucha por el bienestar de todos y la transmisión de valores". Esto de la misma manera que en los conceptos de valor recabados muestra un muy alto grado de concordancia entre la forma de concepción de la familia entre sus miembros.

El 76\% de padres e hijos respondieron que los dos valores más importantes para la familia son el amor y la justicia. Poniéndolos en contraste con otros valores como la libertad, y la compasión y humildad.

Esto se relaciona de manera estrecha con lo que piensan acerca de la importancia de la familia; en ella se transmiten y se conservan los valores, las personas encuestadas respondieron respectivamente que la importancia de la familia se debe a que en ella existe la unión y los integrantes se apoyan en todo momento. 


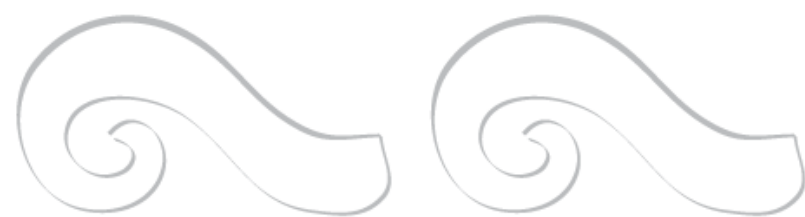

El $76 \%$ de las familias considera de manera común que el papel que toma la escuela en la enseñanza de valores es de un ayudante a la familia en la formación de los mismos.

El $35 \%$ de las familias encuestadas concordaron que el problema más común en la comunidad es el económico, mientras que un $10 \%$ dice que éste es la violencia en la familia, un $55 \%$ respondió que es la indiferencia, la apatía y la falta de valores. De igual manera los integrantes de la comunidad pudieron reconocer maneras de combatir esta problemática entre ellas se recuperó que el $41 \%$ de padres e hijos considera importante la convivencia en familia, y el fomento de la educación.

El 70\% de los padres e hijos coinciden en que algunas actividades que favorecen la unión familiar son el tomar juntos las decisiones y participar juntos en las actividades, Esto se ve reforzado fuertemente ya que de igual manera el $94 \%$ de papás e hijos practican el valor del amor en su familia, aunque al mismo tiempo se ve impedido ya que al $64 \%$ de las familias encuestadas les resulta difícil la práctica del valor amor entre los integrantes de su familia. También se encuentra una gran ilación al identificar que el $100 \%$ de las familias encuestadas les gusta platicar de los valores con los miembros de su familia. Haciendo de esto una gran ventaja para la difusión de ellos dentro de las estructuras familiares de la comunidad.

El $57 \%$ de los niños de 7 a 15 años de edad consideran que un valor es saber cómo nos portarnos, coincidiendo con el $100 \%$ de los adolescentes de 16 a 20 años, mientras que los adultos consideran en un $68 \%$ que un valor es la cualidad que permite aprobar el valor ético de las cosas dignas de aprecio, en estas acepciones se puede observar que los adultos de la comunidad presentan un grado más alto de cognición en la amplitud innata del valor.

El $68 \%$ de 7 a 15 años piensan que la familia es un "Espacio de afecto donde se lucha por el

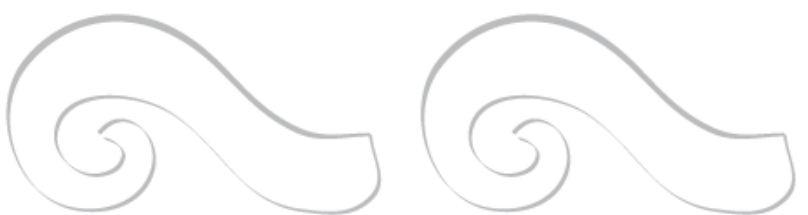

bienestar de todos y la transmisión de valores", de 16 a 20 y mayores de veinte están de acuerdo con ellos. Este porcentaje representa a la mayoría y refleja que las personas de todas las edades están de acuerdo en su forma de percibir lo que la familia es para todos ellos.

El $47 \%$ de niños respondieron que los dos valores más importantes para la familia son el amor y la justicia, contrastando con adolescentes que consideran en $50 \%$ a la compasión, junto con los adultos con un $37 \%$. Dada la amplitud de los valores, las respuestas obtenidas varían mucho en cuanto a los porcentajes.

La respuesta obtenida con respecto a la unión familiar de niños en un $63 \%$ fue "Participación de toda la familia para fomentar valores", estando de acuerdo con $100 \%$ de los adolescentes y con el $72 \%$ de los adultos. Se puede observar que toda la población percibe de la misma manera lo que para ellos es la unión familiar, al mismo tiempo que la familia es importante por que ahí se transmiten y se conservan los valores más importantes.

Un $57 \%$ de los niños consideraron que el problema más común de las familias es de origen económico, el 100\% de los jóvenes cree que es la indiferencia, apatía y falta de valores, mientras que los adultos en un $35 \%$ piensan que son otros factores. En este mismo sentido el $100 \%$ de los jóvenes concordaron en que para dar solución a este tipo de problemas hay que convivir más en familia, mientras que los adultos y niños piensan que son otras medidas las que hay que tomar como la continua convivencia de la familia, que se puede llevar a cabo en las actividades diarias que realizan. El $47 \%$ de los niños, $100 \%$ de adolescentes y $75 \%$ de adultos coinciden en que algunas actividades que favorecen la unión familiar son el tomar juntos las decisiones y participar juntos en trabajo, casa y escuela, en las relaciones que día con día se hacen, desde la simple charla que se hace en 


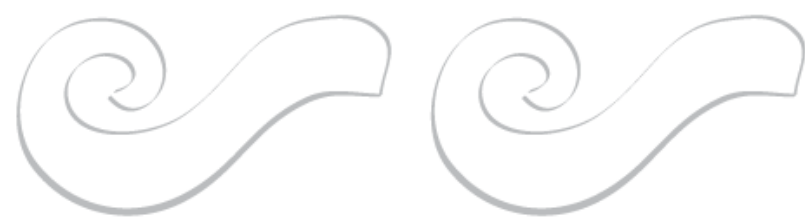

la comida hasta la convivencia cuando van a la milpa a trabajar juntos.

El $73 \%$ de niños, $100 \%$ de adolescentes y $93 \%$ de los adultos precisaron que en su familia se suele practicar el amor como un valor. Al $94 \%$ de los niños, $100 \%$ de adolescentes y $93 \%$ de los adultos les gusta realizar actividades con su familia, lo que se ve un poco impedido ya que al $52 \%$ de los niños les resulta difícil platicar de amor con los integrantes de su familia, aunque al $100 \%$ de los adolescentes es lo contrario, y el $37 \%$ de los padres dice no saber, esto de igual manera impacta en la práctica de los valores dentro de la estructura familiar ya que es una confusión interna de los integrantes, pero se ve apoyada ya que todos los adultos y adolescentes sienten agrado por platicar de valores con su familia, al igual que el $94 \%$ de los niños, esto es un $97 \%$ de la población en general.

El $94 \%$ de los niños concordaron en respuestas al afirmar que para una mejor unión familiar se deben reducir los problemas y los conflictos dentro de ellas, de igual forma que los adolescentes, difiriendo de los adultos que el $41 \%$ consideró que es fomentar y enseñar más valores.

Niños, adolescentes y adultos con un $94 \%$, $100 \%$ y $79 \%$ respectivamente coincide y está de acuerdo que practican la libertad en su casa.

El 31\% de los niños, colocan al amor como valor más preciado, los adolescentes en un $100 \%$ consideran es la libertad, mientras que los adultos contestaron que era la participación.

Para esta investigación también se hizo una comparación de los datos recabados, seleccionados por diferencia de género, haciendo énfasis en la opinión de la mayoría respecto a cada temática:

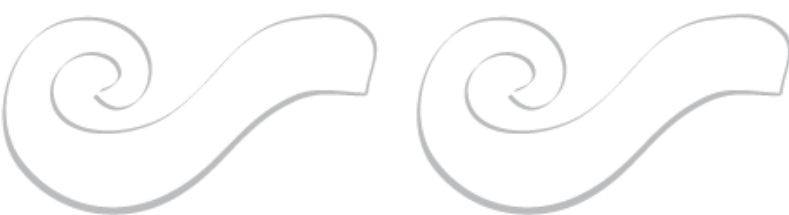

El $63 \%$ de los hombres al igual que el $26 \%$ de las mujeres en la comunidad de Ayahualulco, están de acuerdo que un valor es el saber cómo nos portamos.

El $47 \%$ de los hombres opina que la familia es asegurar la economía de sus miembros y mantener a los hijos, de la misma manera contestó el $63 \%$ de las mujeres. En el mismo sentido otro $47 \%$ de hombres considera que la familia en cambio es el espacio de afecto donde se lucha por el bienestar de todos y la transmisión de los valores.

Dos de los valores más importantes dentro de la familia, como considera el $84 \%$ de la comunidad masculina son la libertad y la humildad con un $36 \%$ y para el $26 \%$ de las mujeres el más importante es el amor. Retomando datos anteriores, podemos observar que en la población sobresalen las mujeres puesto que en los resultados generales el valor predominante es el amor.

El $52 \%$ y el $36 \%$ de los hombres en la comunidad están de acuerdo que la unión familiar es la convivencia entre los miembros y solo los padres toman las decisiones, de igual manera consideran que la familia es importante porque es unida y se apoyan en todo momento.

La escuela en cuanto a la formación de los valores es concebida como la que ayuda a la familia en la educación de los valores, esto es por un $63 \%$ de los hombres y un $76 \%$ de las mujeres encuestadas.

El $57 \%$ de los hombres y el $30 \%$ de las mujeres como mayoría en la muestra concordaron que el problema actual más común en su comunidad es lo económico. El $57 \%$ de los hombres cree que la forma de resolver los problemas es mediante el fomento de los valores y el $43 \%$ de mujeres de la comunidad piensa que esto será posible solo mediante la convivencia familiar, lo cual será posible mediante algunas actividades que favorezcan 


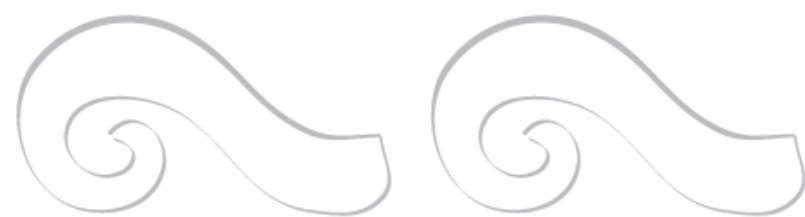

la convivencia, un $47 \%$ y $76 \%$ de hombres y mujeres coinciden que algunas actividades que favorecen la unión de la familia son la participación y la toma de decisiones todo esto en convivencia constante.

El 97\% de la personas están concientes de que en su familia se suele aplicar el valor del amor, al $94 \%$ de los hombres y el $100 \%$ de las mujeres de la comunidad tienen agrado por la práctica de los valores en su familia. Aunque el $47 \%$ de los hombres considera que no le resulta difícil platicar con su familia de los valores mientras que el $36 \%$ de las mujeres dice que si le resulta difícil platicarlo, lo que en realidad reflejado en porcentajes se ubica por debajo de los $50 \%$ lo cual no implica una mayoría absoluta lo que al mismo tiempo facilitará la lucha contra los obstáculos en la práctica que se apoyará del 94\% de la población.

El 36\% de los hombres; representando a la mayoría de ellos, considera que para lograr una mejor unión familiar hay que fomentar y enseñar más los valores, y el $46 \%$ de las mujeres por otro lado consideran que hay que reducir las problemáticas y los conflictos en el interior de la misma.

El $100 \%$ de la comunidad masculina coincide con el $83 \%$ de la femenina que en sus hogares se practica la libertad, por lo que en la comunidad de Ayahualulco, Veracruz es muy importante la práctica de este valor, pues para estas familias es trascendental que los hijos sepan dirigir su libertad dentro de la responsabilidad.

El valor más practicado en las familias según el $26 \%$ de los hombres como mayoría es el amor, y por parte de las mujeres en un $26 \%$ el valor más practicado es la participación. Estos porcentajes se vieron afectados por otros valores como la asertividad, la igualdad, la justicia entre otras, lo que provoca una reflexión mínima de la mayoría.

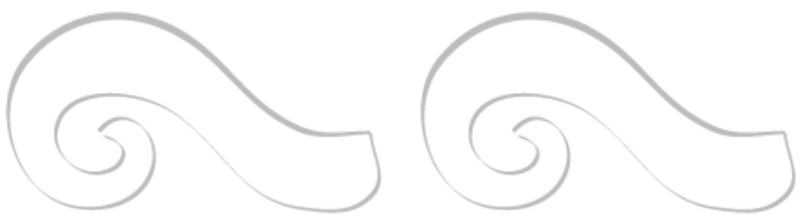

Dentro de la investigación se encontró que el $41 \%$ de la población tienen menos de quince años de edad; el $23 \%$ tiene más de 50 años de edad; $10 \%$ para el rango de entre 35 y 40 ; con $18 \%$ se encuentran entre 20 y 30 años, además de el rango entre 45 y 50; y con el menor porcentaje; $8 \%$ entre 30 y 35 . Se encontró que entre quince $\mathrm{y}$ veinte años de edad existe menos población, mientras que la mayor población se encuentra quince y veinte años, esto gracias a que las personas entre 15 y 20 años emigran a otros lugares para acudir a trabajar, mientras que los que tienen menos de 15 años se encuentran estudiando en el lugar, muchos de ellos están en La Salle.

Dentro de la afirmación acerca del concepto de valor se encontró que la mayoría de la población considera que es la cualidad que permite aprobar el valor ético o estético de las cosas dignas de aprecio con un $57 \%$, esto quiere decir que en la comunidad la mayoría de las personas tienen claro dicho concepto pues es algo que practican dentro de la comunidad; $35 \%$ de la muestra respondió que un valor es saber cómo nos portamos; el $6 \%$ tiene otras concepciones y por último el $2 \%$ que es ajeno a la moral. En general la mayor parte de la población tiene claro el concepto de valor, sin embargo una gran cantidad de ella aun no lo tiene claro o más bien la mayoría de las personas no tienen el conocimiento teórico acerca de esta concepción sin embargo lo llevan a cabo de acuerdo a las experiencias vividas, es decir, tienen un conocimiento empírico.

Para el $65 \%$ de los encuestados la familia es un espacio de afecto donde se lucha por el bienestar de todos y la transmisión de valores; el $25 \%$ contestó que la familia es la que asegura la economía de sus miembros y mantiene a los hijos, lo cual es interesante analizar que son importantes los valores y su transmisión dentro de la comunidad, sin embargo, también consideran como opción importante la economía familiar, pues uno de los principales aspectos es el sustento familiar 


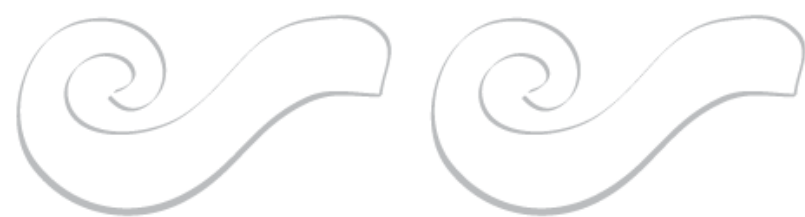

que se tiene; para el $6 \%$ es un núcleo social donde se generan problemas y faltan valores y el $4 \%$ considera otras concepciones de la familia, como la que te ayuda, que te apoya, la que vive en tu casa entre otras.

Los valores más importantes para las personas de la comunidad resultaron ser el amor con $35 \%$ y aunque no es la mayoría se destacó como principal valor que concuerda con la observación que realizamos dentro de la comunidad ya que las familias son unidas en este aspecto, la compasión con $18 \%$, la libertad y la justicia con un $28 \%$, hubo diversidad de respuestas, y aunque la compasión se encuentra en segundo lugar, dentro de los principales resultados se encuentran el amor y la libertad, analizando así que estos valores son esenciales dentro de la familia, por lo tanto se considera que son fundamentales en la unión familiar. Con $8 \%$ se encuentra la participación, $7 \%$ humildad y con $4 \%$ la asertividad y otros valores.

La unión familiar para las personas encuestadas está encaminada hacia dos rubros el primero con $47 \%$ donde la unión familiar es la participación de toda la familia para fomentar valores aunque en ocasiones las familias se desintegran por trabajos que los jóvenes buscan fuera de la comunidad para un crecimiento y bienestar y el segundo con el $43 \%$ referida a la convivencia entre los miembros donde solo los padres toman las decisiones, en esta comunidad la unión familiar está referida a la participación y convivencia de los miembros con la desviación acerca de que los padres toman las decisiones, considerando que la mayor parte de la población es joven y que los padres funcionan como total autoridad en este contexto; el 8\% considera otras concepciones como la idea de que es cuando la familia se ayuda para realizar su trabajo por ejemplo en el campo y el $2 \%$ que cada quien este por su lado.

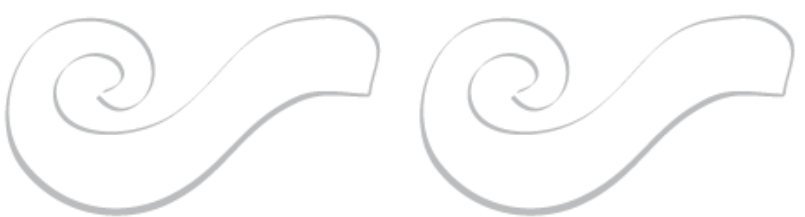

Consideran que la familia es trascendental porque es unida y se apoya en todo momento con un porcentaje de $72 \%$ que representa la mayoría de la muestra, pues para las personas es esencial que la familia esté unida y participe en las actividades cotidianas que realizan, considerando la unión familiar como factor más importante dentro de ella, concepto esencial dentro de esta investigación, 20\% respondió que es importante porque conserva y transmite valores importantes, un $8 \%$ con otras concepciones y nadie respondió porque regañan a los más pequeños. Es importante para la mayoría de los encuestados la convivencia en un ámbito familias pues todos se apoyan entre sí y se ayudan entre su familia.

Para la comunidad el papel que toma la escuela en la enseñanza de valores es mayoritariamente que ayuda a la familia a la educación en valores con un $71 \%$, las personas de la comunidad consideran que la escuela es muy importante en la educación de los valores, el 23\% de la población total comentó que en la escuela nos enseñan valores pero no los practicamos, por lo tanto, la escuela transmite los valores pero dentro de la familia actualmente no se fomenta esto, es impactante que las personas reconozcan que no se practican los valores que la escuela transmite, es importante que se preocuparan para trabajar esta práctica; el 6\% contestó otros factores los cuales la escuela toma como papel como el de enseñar, aprender, conocer entre otras y nadie de la población eligió el que en la escuela no existe la educación en valores; por lo tanto la escuela enseña los valores que son importantes para la unión familiar.

Dentro de la comunidad y con relación al tema del problema familiar actual más común es el económico con un $41 \%$ de la población total, pues interesa más este problema que se vive en la realidad que otras situaciones en ese contexto, sin embargo no se considera que es la mayoría de la población; el $25 \%$ considera que un problema importante es la violencia 


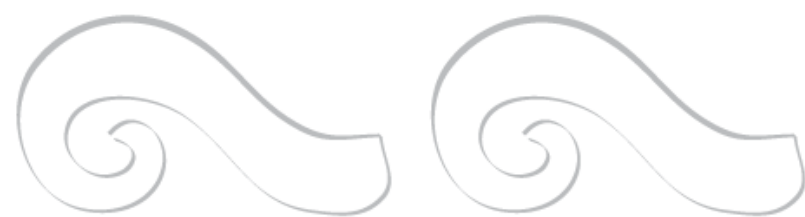

intrafamiliar considerando así que la violencia es importante, aunque no más que los problemas económicos que actualmente se viven en este lugar; el 18\% de la población total eligió que es la indiferencia, apatía y falta de valores, considerando así que este también es un problema importante y grave; por último el $16 \%$ de los encuestados comentaron otros problemas. Por lo tanto existen diversos problemas dentro de la comunidad que es importante resolver desde distintas perspectivas y dimensiones humanas, es decir no únicamente existen problemas de valores $\mathrm{y}$ unión familiar.

Con relación al tema de resolver estos problemas propusieron en igual porcentaje el convivir más en familia y nos propusieron otras situaciones con $41 \%$ cada una, las situaciones que nos propusieron fueron trabajar en familia, ahorrar entre otras; un $18 \%$ considera que la solución es la educación en valores; por último nadie considera que la solución es seguir peleando y no dejarse. Una de las respuestas más importantes es que la familia en general está preocupada por el sustento que se vive y el bienestar económico dentro de la comunidad.

Algunas actividades que las personas nos comentaron que favorecen la unión de la familia son con un $65 \%$ tomar juntos las decisiones y participar juntos en las actividades, es decir, que la mayoría de la población considera a la familia como institución esencial para participar en familia juntos que se refiere a la unión familiar y por lo tanto las familias en general van a pasear, trabajan entre otras actividades que favorecen esta convivencia; el $27 \%$ de la población total considera que la respuesta es fomentar los valores; el 6\% sugirió otras respuestas como trabajar o ayudar al quehacer del hogar y el $2 \%$ de la población nos respondió que para favorecer la unión familiar se tiene que ir cada quien por su lado, cabe mencionar que aún se tienen ideas de este tipo cuando la mayoría de la población se encamina a la unión familiar y valores.

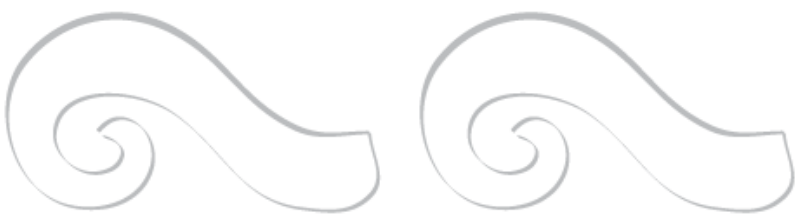

El $86 \%$ de las personas de la comunidad platica del valor amor con su familia y el $14 \%$ no suele platicar con su familia de este tema, cabe mencionar que las personas de la comunidad, conocen este valor y suelen platicar acerca de este con su familia.

Con relación al tema anterior acerca del amor el $37 \%$ de la población contestó que no les resulta difícil hablar de esto con su familia, mientras que el $35 \%$ las resulta complicado y el $28 \%$ un poco, esto quiere decir que aunque la mayoría de las personas suelen hablar con su familia del valor del amor, les resulta difícil o un poco difícil hablar de esto; por lo tanto se considera que les cuesta trabajo por el mismo contexto en el cual viven, la cultura, educación entre otras.

El $96 \%$ de la población les gusta realizar actividades junto con su familia, es decir, la mayoría de las personas realizan actividades como trabajar, hacer quehaceres, pasear por el pueblo entre otras, siendo las anteriores las más representativas y solamente el $4 \%$ no, por lo tanto, la mayoría de las personas realiza actividades con sus familias, eso quiere decir que con las actividades que realizan juntos fomentan la unión de su familia dentro de los valores que también la escuela enseña y transmite, esto dentro de su contexto particular y desde como los mayores fueron educados $\mathrm{y}$ así transmitir a las nuevas generaciones.

A la mayoría de las personas de la comunidad les gusta la práctica de valores con su familia, con un $98 \%$, es decir que las personas les gusta la práctica de valores y lo hacen realizando actividades como el trabajo o quehaceres que juntos suelen hacer en su vida cotidiana y solo el $2 \%$ no les gusta practicarlos, este porcentaje no es significado para la muestra ya que únicamente una persona contestó la respuesta como negativa. Por lo tanto para las personas de la comunidad es muy importante la transmisión de valores a su familia. 


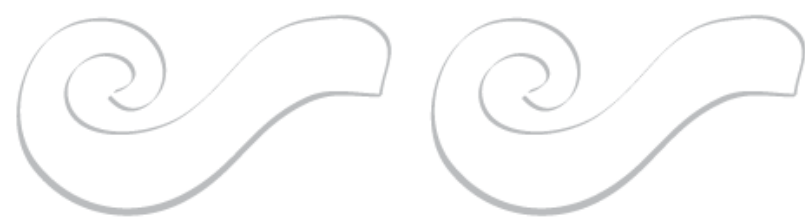

Lo que las personas de la comunidad proponen para una mejor unión familiar es con un $41 \%$ fomentar y enseñar más los valores para así los jóvenes apliquen estos que son muy importantes, el 33\% proponen menos problemas y conflictos y el $26 \%$ de la población propone otro tipo de propuestas como la convivencia familiar, estar juntos, hacer el trabajo de la familia juntos como en los sembradíos o pastoreando; esto se refiere a que actualmente se preocupan por que la familia esté unida y por el bienestar de todos, de acuerdo a lo que pudimos observar las madres de familia son las que se preocupan más por estos temas.

El $90 \%$ de la población cree que su familia practica la libertad, el $6 \%$ a veces practican este valor y el $4 \%$ no sabe si lo hace, es decir, que con relación al tema del amor, les resulta más fácil hablarlo y practicarlo, que el de la libertad aunque algunas personas nos comentaron la idea de que sus hijos a cierta edad ya son libres de tomar sus decisiones y realizar lo que más les convenga para sus vidas. El valor del amor es esencial para la convivencia y unión familiar, es el valor fundamental de toda familia, y con él se derivan otros valores; lo importante es saber aplicarlo, practicarlos y transmitirlos encaminados hacia el bien.

En relación con el tema de la práctica de valores son diversos, con un $23 \%$ la libertad es mayor, gracias a que el amor es lo más importante en cuanto a sentimientos, ya que las personas sienten amor por su familia pero practican más la libertad.

El valor más practicado en la comunidad de Ayahualulco Veracruz es la libertad con un $23 \%$ ya que las personas la ejercen cuando sus hijos cambian su domicilio para trabajar o al casarse, por lo tanto los familiares respetan sus decisiones y los jóvenes ejercen su libertad; el amor con un $21 \%$ es esencial en la unión familiar; la participación como tercera opción con un $18 \%$, esto se da con la convivencia y el

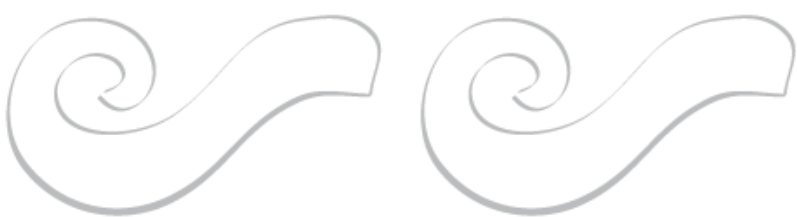

trabajo cotidiano de la familia antes mencionado;

La familia se encuentra preocupada por los valores, su transmisión y la unión de la misma; sin embargo existen diversos factores que probablemente sean de mayor o igual importancia como la economía dentro de la comunidad ya que es muy importante que las personas tengan que comer y gracias a sus experiencias se practican estos valores, sin embargo existe menos conocimiento teórico sobre estos temas, en general la familia es unida dentro de la comunidad, sin embargo la emigración produce un poco d desintegración ya que las personas a cierta edad salen a trabajar para un mejor bienestar económico. Actualmente en la comunidad aún se viven valores importantes para la sociedad y la unión familiar, algunos ya no se llegan a observar en la ciudad como el saludo, amabilidad, cortesía, respeto de las cosas materiales de los demás entre otras cosas.

\section{Talleres}

Dentro de la comunidad de Ayahualulco Veracruz, se realizaron dos talleres el primero con el tema de libertad y el segundo con el tema de amor; el objetivo general fue: impulsar el valor del amor y la libertad en las familias de dicha comunidad; se trabajó con padres de familia que pertenecen al consejo de padres dentro de la Salle Ayahualulco.

Dentro del primer taller acerca de la libertad se realizó una inducción donde los participantes realizaron un dibujo de su familia, un símbolo que la identifique y un valor que fuese importante para ellos, después se realizó una conversación acerca de sus dibujos y del significado que para ellos tiene su familia, donde se desarrolló una mesa de conversación entre todos los padres de familia acerca de diversos temas relacionados con la familia. 


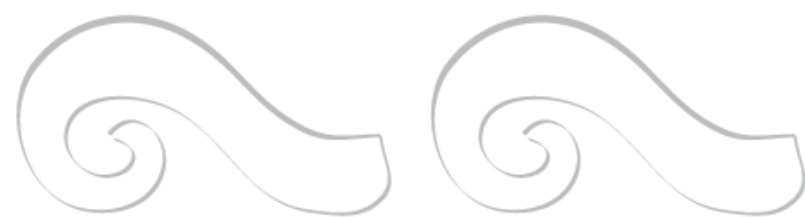

Después se expusieron los temas más importantes con respecto al tema de libertad como el concepto de libertad, algunos autores que hablan sobre dicho valor, la libertad y la familia y algunas estrategias para el fomento del valor antes mencionado, donde se desarrolló una mesa totalmente de discusión donde los padres de familia participaron de manera activa en su experiencia y sus opiniones acerca de las ideas más relevantes del tema, por lo tanto, nosotros proporcionamos la teoría acerca del tema y ellos las experiencias dentro de las diferentes familias, lo cual se complementó y con la participación de todos se realizó un taller real, al final concluimos con una canción titulada "Volver a creer" de José y los padres escribieron y firmaron una estrategia para fomentar dentro de su familia. Con todos los dibujos se realizó una collage que fue pegado en las oficinas de la escuela.

Como inducción del segundo taller con el tema de amor, los participantes se dieron un abrazo afectuoso como manifestación del amor, después se impartieron las temáticas como el concepto de amor, algunos autores que hablan de amor, los tipos de amor que existen, el amor en la familia y algunas estrategias para fomentar dicho valor en la familia, los cuales también se complementaron con la participación activa de los padres de familia, por lo tanto, se realizó una mesa de discusión.

Después de los dos días de trabajo, se escribió una reflexión acerca del valor de la familia y se quedó como pequeña tarea el compartir lo aprendido y lo escrito con su familia, finalmente se escuchó la canción titulada "Color Esperanza" de Diego Torres, realizando reflexiones y retroalimentación de la canción.

El objetivo de estos talleres se cumplió de manera satisfactoria, se realizaron talleres de calidad con la participación y el interés propio de los padres de familia, se realizó en dos

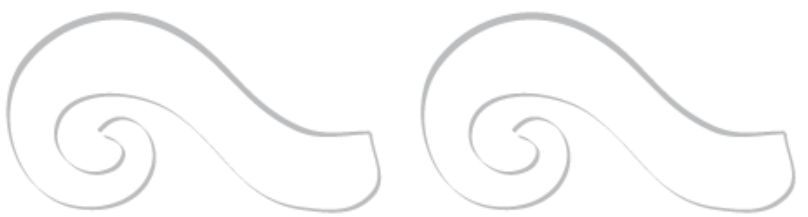

ocasiones el taller referido al valor del amor por petición de los padres de familia; aprendieron mucho en los talleres y los coordinadores de dicho talleres aprendieron a la par con las experiencias de los padres, realmente fue muy gratificante realizar dichos talleres.

\section{Conclusiones}

El problema de investigación parte desde la modificación de la jerarquía de valores, donde actualmente son más importantes los valores estéticos y hedonistas establecidos por la sociedad en lo que además las cosas materiales han tomado mayor importancia; dentro de la investigación realizada en la comunidad de Ayahualulco Veracruz se recabaron datos que revelaron una modificación parcial en la jerarquía de valores gracias a la existencia de influencias externas como los medios de comunicación, la misma sociedad, sin embargo los valores como el amor y la libertad siguen persistiendo en dicha comunidad en la que la escuela toma un papel muy importante en la formación de valores que favorecen la unión de la familia.

La investigación arrojó la existencia de un fortalecimiento de unión familiar desde el amor y la libertad en la comunidad ya que de acuerdo a los resultados obtenidos la mayoría de las personas habitantes de dicha comunidad hacen referencia al amor y libertad como valores esenciales para la unión, funcionamiento y desarrollo familiar, además cabe resaltar que el fortalecimiento de la unión familiar se ve sustentado por otros valores como la justicia, humildad, asertividad, respeto, tolerancia, compasión entre otros. El amor y la libertad son la base de la familia ya que de ellos desprende la unión que se ve reflejada en las ideas esenciales para la familia conformadas por la comunidad respecto a sus valores y la práctica de los mismos como apoyo, tolerancia, respeto, 


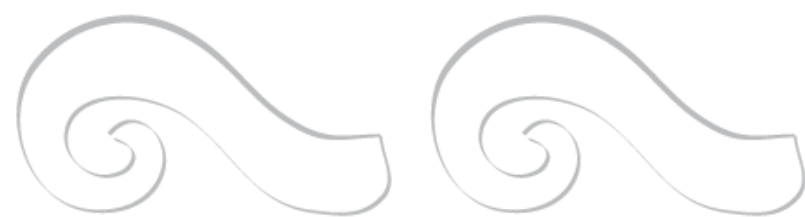

cariño, solidaridad, acompañamiento etc, y como respuesta dan seguridad y confianza familiar que genera la unión de la misma.

El objetivo de esta investigación es comprender el fenómeno de la unión familiar desde los valores como el amor y libertad; el cual fue cumplido de manera satisfactoria ya que dentro del desarrollo de esta investigación se comprendió este fenómeno con las platicas que se presentaron y que se vio reflejado en comentarios recibidos de los padres participantes en los talleres impartidos, además de sus experiencias vividas, en las cuales compartieron con el grupo la forma en que ellos concibieron y aprehendieron la información recibida y la forma en que aplicaban y podían seguir aplicando dicha temática dentro de cada ámbito familiar, esto gracias al apoyo de las personas de esta comunidad y el trabajo de los investigadores.

De acuerdo al supuesto presentado referido a la modificación de la jerarquía de valores y toma de conciencia del papel de los valores dentro del ámbito familiar se puede explicitar a partir de los talleres de valores de la familia se alcanzaron los objetivos pues se presentó una comprensión acerca de esta severa modificación que se ha dado en la actualidad por lo tanto se logró concientizar a los padres sobre este tema, donde existe una modificación de valores, sin embargo persisten valores importantes que cabe rescatarlos desde la familia.

El enfoque retomado en esta investigación está referido al cualitativo ya que acudimos a la comunidad de Ayahualulco Veracruz, es decir, el campo natural, además está referido a temas internos del ser que fueron descritos cualitativamente, por lo tanto este enfoque se cumplió también por las visitas que se realizaron a las casa de las personas en las que se dio un acercamiento interpersonal, con el diálogo, experiencias y vivencias lo que se vio reforzado con los talleres de familias orientados hacia los valores principalmente el amor y la libertad.

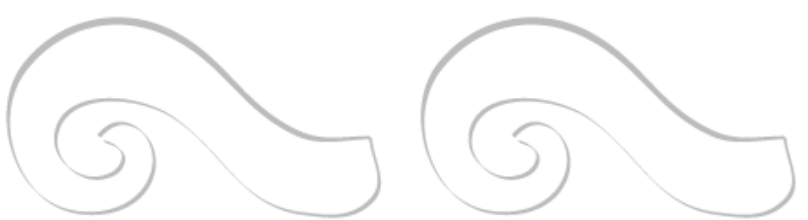

De igual manera este tipo de enfoque se hizo notar al momento de la recolección de información, y el uso de instrumentos utilizados para la investigación, los cuales fueron, entrevistas y guías de observación, realizados en el contexto natural de los entrevistados, esto es en sus hogares.

En los resultados se observa que las personas toman como aspecto trascendental los valores desde la familia, las personas saben lo que es un valor y practican los mismos, sin embargo las personas mayores toman mas en cuenta estos temas, sin embargo siguen existiendo influencias externas que conllevan a la comunidad hacia valores hedonistas $y$ materialistas, toman a la familia como un ámbito de bienestar común aunque es esencial la manutención familiar y el estado económico en el que se encuentran, los valores mas importantes en la comunidad son el amor y la libertad ya que se considera importante la transmisión de estos desde la familia además que la escuela funciona como la institución que enseña y fomenta la práctica de los mismos, en esta comunidad existe unión familiar con valores esenciales para esta, donde los hijos fomentan la unión con ayuda a los padres en los quehaceres o trabajo, además los padres transmiten estos valores con su familia y otras personas; valores que se practican actualmente en la comunidad.

Los aportes centrales resultado de la investigación se encuentran en la práctica de valores desde la familia, sin embargo de acuerdo al taller de familias se contribuyó en el conocimiento de las familias de que los valores son algo trascendental para el progreso, que favorece a un desarrollo optimo y convivencia familiar además de la unión que se genera a partir de estos hechos, con los talleres presentados se dio una concientización de las personas hacia la importancia de estos valores donde su transmisión es de esencial importancia hacia los más pequeños de la comunidad para que no se pierda esta cultura. 
Algunos límites a los que nos enfrentamos fueron el clima ya que estuvo lloviendo en diversas ocasiones, el lenguaje de las personas no estaba tan elevado por lo que se tuvo que modificar la entrevista con palabras y términos más sencillos, la disposición de las personas que se resolvió con la plática y el diálogo, es decir, que no únicamente se presentó el instrumento de investigación sino que se realizó una platica en la cual las personas nos compartieron sus experiencias.

Un obstáculo más dentro de la investigación fue la baja de uno de los investigadores, hecho que complicó la planeación, la organización y la ejecución de la investigación, reflejado en mayor medida en la parte final de la misma, esto es el análisis e interpretación de los resultados.
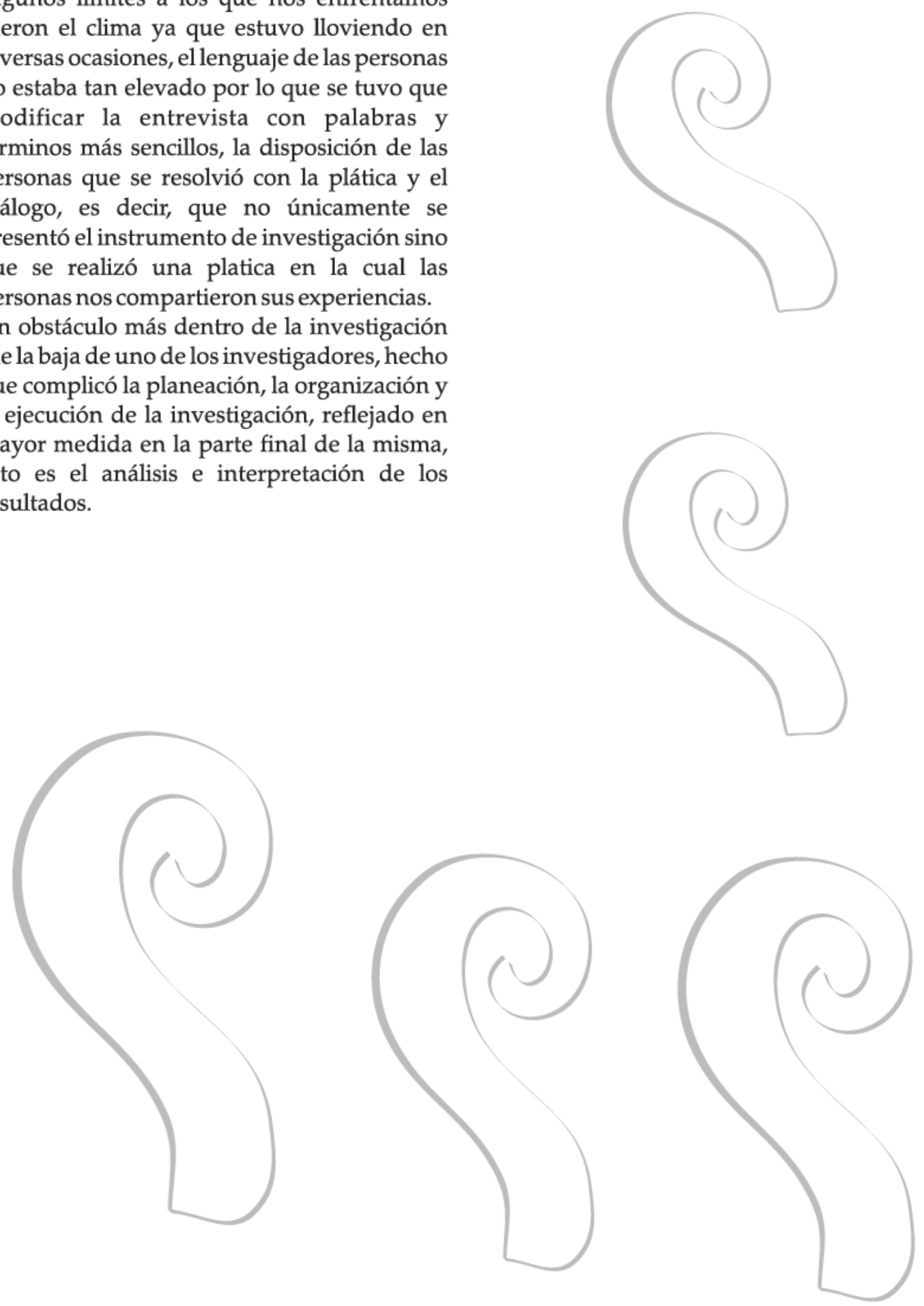


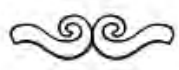

ANEXOS I

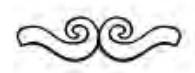

\section{Taller de familias}

\section{Objetivo: Impulsar el valor del amor y la libertad en las familias de Ayahualulco, Veracruz.}

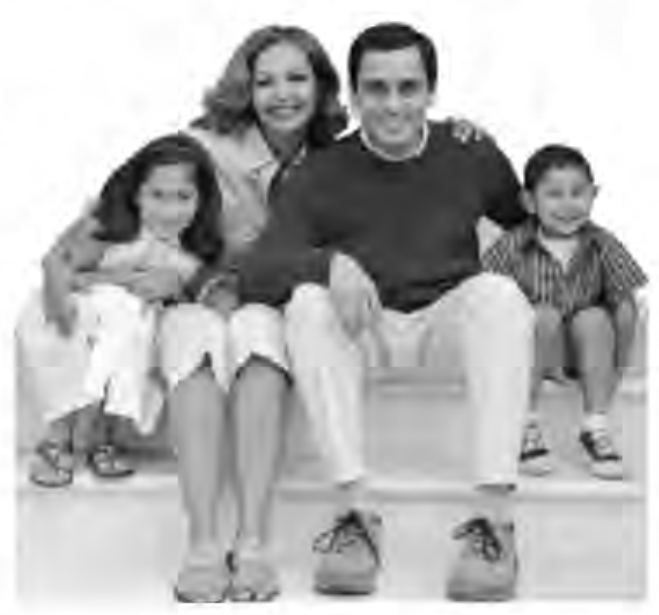

"La familia es el medio necesario para conservar y transmitir valores culturales, educativos y formativos entre sus integrantes ${ }^{\prime \prime 1}$. Ya que es la base de la sociedad y es responsabilidad de los padres transmitir estos valores y así fomentar la unión en la familia para mejorar el desarrollo de quienes la integran.

Según la CNDH en el "Programa para el fortalecimiento de la familia" (2003, pág.8), "La familia es un grupo de personas unidas por parentesco y por lazos afectivos que permiten las interrelaciones entre ellos". La familia además del lazo sanguíneo es un conjunto de personas en el que se comparten distintos tipos de relaciones que ayudan a la formación social de cada uno de los integrantes, mediante la convivencia constante.

Según Mariana Perillita Nava, en el ensayo Los valores y la juventud de hoy (2000, pág. 17). "Un valor es un don intrínseco del ser humano que puede hacer crecer mediante la perseverancia en el mismo y que lo lleva a su perfeccionamiento". También un valor tiene una objetividad en el cual todos los seres humanos aprendemos, pero cada quien lleva estos valores de acuerdo a sus circunstancias y cada quien las mira desde diferente perspectiva como dice Kant "Tú eres tú y tus circunstancias" pero existe una línea de cada valor por la cual se debe seguir.

Es importante definir los valores fundamentales para la unión familiar, ya que el reconocimiento de estos hará cumplir mejor el objetivo, según Ramón Tallabs estos son: amor y libertad además de participación, asertividad, justicia, compasión y humildad, valores que a continuación se definen.

1 Comisión Nacional de los Derechos Humanos (2003). Programa para el fortalecimiento de la familia. México, D.F. pág 5. 


\section{Taller de familias \#1}

Tema:Libertad

Objetivo: Clarificar el concepto de libertad en las familias.

\section{Concepto}

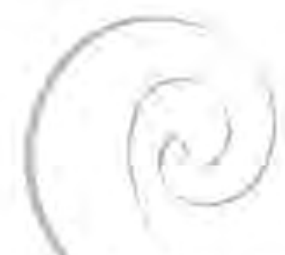

Libertad: "Es la capacidad que tenemos las personas para escoger entre una y otra cosa la mejor; lo mejor es todo aquello que te ayuda a crecer en tus capacidades, que te hacen ser mejor persona beneficiando a los demás; es por eso que cuando escogemos ser justos, compasivos y misericordiosos, estamos siendo libres, porque la libertad es para amar, para poder ser feliz amando y hacer felices a los demás ${ }^{\prime 2}$. Este valor ayuda a aprender acerca de los propios errores y a crecer como personas, pero es importante saber elegir bien para tener buenos resultados.

Etimológicamente la palabra viene del latín "líber", lo que se interpreta como "persona cuyo espíritu de procreación se encuentra activo" ${ }^{\prime \prime}$.

\section{Autores que hablan de libertad}

Rene Descartes: "...consiste solamente en que, para afirmar o negar, perseguir o evitar, las cosas que el entendimiento nos propone, obramos de manera tal que no sentimos que ninguna fuerza fuerce."

Spinoza: "...es libre lo que existe únicamente por necesidad de su naturaleza y solo por ella/se determina la acción".

Para Aristóteles, la libertad está ligada a la capacidad de decidir por sí mismo en el ser humano, y estaba ligada a la moral.

Según San Agustín, la libertad consiste en la realización efectiva del bien, para alcanzar la beatitud.

Para Hegel, el concepto es fundamentalmente la libertad de la idea.

Según Henri Bergson, la libertad es la capacidad de la conciencia de regirse por su propia naturaleza, independiente delas leyes y fenómenos de la naturaleza ${ }^{ \pm}$.

Según Ricardo Yekes Stork la libertad: "Es una de las notas definitorias de la persona. Permite al hombre alcanzar su máxima grandeza pero también su mayor degradación. Es quizás su don más valioso porque empapa y define todo su actuar. El hombre es libre desde lo más profundo de su ser. Por eso los hombres modernos han identificado el ejercicio de la libertád con/la realización de la persona: se trata de un derecho y de un ideal al que no podemos ni queremos

2 Tallabs Ortega Ramón. (2000). Crece valores para la vida 6 primaria. Ed. Fomento Educativo. México Pág. 32 3 Mis respuestas,com. (2009). ¿Qué es la libertad?. Recuperado el 29 de Agosto de 2009, en: http://www.misrespuestas.com/que-es-la-libertad.htmI

4 Mis respuestas.com. (2009). ¿Qué es la libertad?. Recuperado el 29 de Agosto de 2009, en: http://www.misrespuestas,com/que-es-la-libertad,html 
renunciar. No se concibe que se pueda ser verdaderamente humano sin ser libre de verdad" ${ }^{5}$. El hombre con la libertad de decidir lo mejor para él se siente auto-realizado y cuando elige mal y vienen consecuencias y estas son negativas se siente degradado. La libertad se ha convertido en derecho importante para el ser humano.

La libertad es lo que permite decidir al hombre si algo es mejoro o no, si quiere o no hacer algo; en este sentido es muy importante porque de esta manera el hombre es libre, pero lo lleva a tener responsabilidad en sus actos, también cabe mencionar que la libertad es inherente al hombre y se sitúa en el interior de la persona con la inteligencia y voluntad.

Chesterton (2004) comenta que la familia es el centro de la libertad. Ahí es donde podemos ejercer nuestra libertad de manera real y sin la influencia de los demás. El hombre libre es el que se compromete con lo que realiza, esto lo lleva a renunciar al objeto que no es compatible con lo que se ha comprometido, por ejemplo, el hombre renunciará a las ideas que no sean compatibles con su religión o con algo con lo que se haya comprometido y finalmente el hombre libre es un hombre generoso principalmente en la familia, es decir, entregarse a sí mismo.

Es importante que en la familia se practique una educación libre ya que es necesario que cada miembro aprenda a decidir su libertad, ser autónomo y por lo tanto a enfrentar las consecuencias de sus actos.

\section{La libertad y la familia y algunas estrategias}

No sólo porque en ella el hombre se siente libre, y puede actuar de una manera que sería irrepetible fuera de su casa. Es cierto, como dice el propio Chesterton, que «el hogar es el centro de la libertad... Más aún, es el único centro de la anarquía. Es el único punto del planeta cuyo arregloel hombre puede alterar súbitamente...

Donde puede hacer experimentos o permitirse un capricho. En todo lugar a donde vaya, debe atenerse a las normas estrictas de la tienda, la taberna, el club o el museo. En su propia casa podrá, si le da la gana, comer sus comidas en el suelo. Yo mismo lo suelo hacer y ello me produce una infantil y poética impresión de excursión. Provocaría considerable trastorno si tratara de hacerlo en un restaurante. Es el único lugar tranquilo, el único lugar salvaje en un mundo de reglamentos y de tareas. Uno solamente puede retozar en su casa, pequeña omnipotencia humana, cámara de la libertad».

La familia no es el centro de la libertad porque pueda ser el rincón privilegiado de nuestros caprichos. No estoy muy seguro de que la esposa de Chesterton suscribiera sus extroversiones hogareñas.

La familia es el centro de la libertad, el lugar propio de su desarrollo y expansión, porque es el caldo de cultivo de los tres componentes que constituyen la esencia de la libertad: la capacidad de compromiso, la capacidad de renuncia y la capacidad del don de sí.

5 Colaboradores de Wikipedia (2009). Libertad. Recuperado el 28 de Mayo de 2009. en: http://es.wikipedia.org/wiki/Libertad 


\section{Primero, la capacidad de compromiso}

La familia es una gozosa fuente de compromisos, de compromisos profundos, serios e inamovibles, que el hombre bien nacido asume con valentía y decisión. El hombre libre no es el que carece de vínculos, sino, al revés, el que se encuentra comprometido en profundidad. Como acontece con elárbol bien radicado, cuanto más profundas son sus raíces, más libre se encuentra para resistir el vendaval; al contrario, la arena suelta del desierto, libérrima carencia de ataduras, es esclava de cualquier brisa ligera. Una persona que no se encuentra dentro de una familia, con todo el valor de la preposición, es un individuo erradicado, voluble, carente de ligaduras, habitante de la nada.

\section{Segundo, la capacidad de renuncia}

El compromiso implica la renuncia de todo aquello que es incompatible con el objeto con el que me he comprometido. La renuncia es el gran ausente de nuestra civilización. No somos capaces de compromiso por nuestra constitutiva incapacidad de renunciar a nada. Y somos incápaces de renunciar porque hemos atrofiado nuestras posibilidades de compromiso que son-digámoslo de una vez - posibilidades de amor.

$\mathrm{El}$ amor es el único precio de la renuncia. Yo me lo he preguntado muchas veces: ¿qué precio tiene una sonrisa?, ¿cómo se paga el galante acercamiento de una silla?, iqué cuenta presento cuando visito a un amigo enfermo?, ¿qué ocurriría si nos declaramos en huelga y cesaran todas estas acciones libres y personales hechas al margen de la política o de la economía?, o, peor aún, ¿qué sucedería si pasáramos factura por ellas? ¿En dónde, fuera de la familia, se aprende a sonreír, a servir, a practicar su ayuda al otro? Esto es, ¿en dónde, fuera de la familia, se aprende a serlibre?

Tercero, la capacidad del don de sí

No necesitamos muchas palabras para percatarnos de que si hay un lugar en la vida, si hay un espacio en la sociedad en donde se ensaya, practique y ejercite el acto supremo del don de sí, es en la familia. $Y$ que fuera de la familia es difícil y excepcional el acto de entrega de la persona. $O$, por mejor decir -y para decirlo como Friederich Hegel-, quien no haya aprendido a ser generoso en el hogar, difícilmente podrá serlo después, aunque quisiere, en el ámbito público. La entrega desinteresada de sí corre pareja con el sentido de responsabilidad, con el control de los instintos, con el temple de las capacidades, con el dominio del yo, con la afirmación del carácter.

La entrega de sí mismo no sólo es el acto cimero de los seres libres, su ejercicio más noble y perfecto; no sólo es el acto fundamental para la educación de nuestra libertad. És el acto educativo por excelencia. En las escuelas pueden aprenderse oficios determinados y útiles, mientras que en la familia se aprende - cuando se aprende - el más alto y fundamental de los menesteres: el de ser hombre.

Esta entrega de sí - que se esponja en el ámbito familiar - sigue derroteros distintos a los de las transacciones mercantiles; en cierto modo, resulta su antípoda. Si en el mercado se trata de 
conseguir to mấs contra lo menos posible, en el don de sí se trata de entregarlo todo por nada. ¿Fuera de la familia, en dónde es posible encontrar la fraternidad?

En el mundo de la vida pública rige el criterio operativo de la eficacia; se trata de alcanzar aquello de loque carecemos por ese movimiento fuerte del ser humano que llamamos desiderium. En el mundo ordinario de la vida familiar rige el criterio operativo de la fecundidad, por ese movimiento, no menos compulsivo y apremiante, llamado effusio, que nos impele a compartir aquello que tenemos. La eficacia persigue lograr objetivos; la fecundidad, expandirse en frutos.

Hoy, por fuerza del mercantilismo imperante, se ha propalado la errónea idea de que el impulso natural del hombre es el del deseo de remediar nuestras carencias, y no la efusión de nuestra plenitud. Los muchos que así piensan han marginado precisamente la vida familiar y su profundo mordiente educativo; han marginado la vida del espíritu, la cual se acrecienta al compartirse, limitándose sólo a la materia que se pierde cuando se comparte. Acertadamente lo decía Machado: «moneda que está en la mano tal vez se deba guardar». (Bien se ve que el poeta es andaluz y no regiomontano. La moneda no se debe tal vez guardar: debe guardarse sin duda alguna) «Moneda que está en la mano tal vez se deba guardar, la monedita del alma — sigue Machado-se pierdesino se da».

Para ilustrar el imperioso instinto de la effusio, de la entrega de sí, me valgo de un ejercicio tomado de mi colega Pérez López: el caso del niño en la noche lluviosa. En un automóvil utilitario y pequeño, en una noche lluviosa viajo imprudentemente por una carretera estrecha, a doscientos kilómetros por hora. A parece una vaca, que atraviesa la carretera, con cuyo impacto mi vida acabaría de modo irremediable. Aún lograría salvarla si, apretando el acelerador, pudiera librar el reducido espacio que el cansino andar de la vaca me permite. Me apresto a ello cuando, en el breve trecho disponible, aparece un niño de siete años persiguiendo una pelota. El ejercicio termina con la decisión de ustedes: si dirigen el automóvil contra el niño — salvando la vida de ustedes - o la dirigen contra la vaca - perdiendo ustedes su vida y salvando la del niño. (El estadó de la vaca no entra en la decisión).

Tengo la certeza moral de que casi la totalidad optaría por donar su propia existencia a un niño desconocido, abandonado y - como el del incendio- sobrante e inútil. Nadie se encuentra dispuesto a seguir viviendo con un niño de siete años debajo de las ruedas de su Tsuru o su VolksWagen.

Dijimos que la donación de sí mismo es la contrapartida de las transacciones mercantiles. Pero diremos ahora, además, que la comunicación que se da en la familia es el polo opuesto de la que rige en el mundo de los medios de la comunicación social. Habermas, desde una ideología diversa de la nuestra, ha acertado al decir que el paradigma de la comunicación no verbal es la de la madre con el hijo en su seno. Una comunicación que dista mucho de ser silenciosa: se constituye, al contrario, en una voz existencial magna y amplificada, aunque sea sin palabras, porque es - y las madres en cinta lo saben bien-la donación de la vida.

Sé me dirá que describo una realidad romántica e idealista. Yo digo, en cambio, que ésta es la realidad verdadera, y no la de las fantasías publicitarias, la de los engaños pragmáticos mercantiles, la de los vacíos discursos políticos. Pero si así no fuese, recordaré que cuando algunos censuraban a Zenxis por haber pintado hombres que no pueden existir en la realidad, 
Aristóteles contestaba: «la respuesta justa es que lo imposible verosímil debe ser preferido a lo posible no convincente".

\section{Estrategias de libertad en la familia}

Libertad para elegir, libertad para salir, libertad para volver, libertad para comprar, libertad para comer, libertad para decir, libertad para hacer, libertad para sentir, libertad para escribir, libertad para leer, libertad para crecer, libertad para...

Pasear sólo

- Escucharlo-dejarlo expresarse.

- Establecer reglas para poder salir: conocer amigos, dejar teléfono, tiempo, haber cumplido responsabilidades.

- No hacerlo sentir mal si no nos parece la idea.

- Dar razones.

Tareas de casa

- Tarea adecuada a su edad-platicarlo con él(ella).

- La repetición de la tarea (tiempo).

- Consecuencias por no hacerla.

Incomodidad ante la disciplina

- Explicar concepto de libertad-limite: dignidad del otro.

- Pensar (Padre-Hijo) en las posibles consecuencias de sus actos.

- Aprovechar circunstancias- no usarlas en su contra.

- No imponer-dialogar.

Tiene un problema

- Escuchar el problema.

- Hablar sobre cómo resolverlo: no dar solución tajante.

- Darle tiempo para pensarlo.

- Que él decida la solución y respetarla. 


\section{Taller de familias \#2}

Tema: Amor

Objetivo: Clarificar el concepto de amor en las familias.

\section{Concepto}

Amor: "Es interesarse por alguien, querer estar cerca y compartir con él. Es un sentimiento especial que te llena el corazón. Amar a alguien significa tratarlo con mucho cuidado y bondad, porque te importa mucho. El amor se puede demostrar con una sonrisa, una manera agradable de hablar, un acto considerado o un abrazo. Amar es ponerse en el lugar del otro y preocuparse por lo que siente. Es aceptar a los demás tal como son. También se puede amar a los desconocidos, simplemente interesándote por lo que les sucede. Amar es tratar a otros tal como a ti te gustaría que te trataran: con atención y respeto" ${ }^{\prime \prime}$. Es uno de los valores fundamentales en la unión familiar, pues de este se derivan muchos valores como la confianza, amistad, lealtad, fidelidad, convivencia, comunicación, cariño, afecto, empatía; ya que cuando se ama a una persona se le respeta, se le tiene confianza entre otras, cosas que se fomentan desde la familia. En la actualidad la familia está perdiendo estructura y por lo tanto se ha dado una pérdida de valores que han sido sustituidos por materialismo y consumismo en donde las personas hacen de las cosas necesidades que realmente no lo son.

\section{Autores que hablan de amor}

Para Gottfried Leibniz, "Amar es encontrar en la felicidad de otro tu propia felicidad" ${ }^{\prime 7}$. Es darse al otro sin esperar nada a cambio, "es la entrega que se tiene hacia los demás" ${ }^{8}$, por ejemplo, cuando una persona de tú familia está bien, tú estás bien y cuando está mal o pasa algo, tratas de tomar estrategias para hacerlo sentirse bien.

La caridad es una manifestación del amor y es el nivel más elevado y sobrenatural de este, es el amor desinteresado a los demás y conforma una de las virtudes teologales, es decir, como anteriormente se mencionó darse a los demás.

El amor es un valor fundamental en la familia, en ella se enseña a amar desde la infancia, de ello dependerá si en el futuro la persona es capaz de amarse a sí mismo y amar a otros; este promueve la unidad y comunicación, pues si amas a tu familia buscaras su felicidad y estarás más unida a ella.

Este valor es visto desde distintas perspectivas, y cada persona lo ve de acuerdo a sus experiencias por la vida, es decir, el amor es visto por cada familia de diferente forma de acuerdo a su cultura, forma de vida, costumbres, creencias, vivencias, entre otras.

La familia crece rodeada de aspectos externos como los conflictos, lo importante es que con el amor, la libertad, la convivencia y otros valores se resuelvan estos conflictos en un ambiente sano y hacia un futuro exitoso de la formación en valores.

6 Tallabs Ortega Ramón. (2000). Crece valores para la vida 6 primaria. Ed. Fomento Educativo. México.Pág.35

7 Colaboradores de Wikipedia (2009). Amor. Recuperado el 28 de Mayo de 2009. en,

http://es.wikipedia.org/w/index.php?title $=$ Especial:Citar\&page $=$ Amor\&id $=26814866$

8 Intervenc. Sistémica y T. Familiar Esc. Vasco-Navarra y Sant-Pau de TF. El amor en la convivencia familiar. Recuperado el 28 de Mayo de 2009, en http://ptobal.wordpress.com/2008/03/25/el-amor-en-la-convivencia-familiar/ 
En conclusión el amor está en la vida que comparte y construye una familia.

"Amar significa ayudar al crecimiento personal del otro al tiempo que crecemos nosotros. Amar de verdad significa compartir tú vida con alegría, dialogar sobre diferencias y preferencias, sobre lo que nos une y lo que nos separa y sobre todo amar significa respetar la integridad del otro". Amar es buscar lo bueno para cada persona y para su familia, es encontrar en él la razón para hacer las cosas, también es importante mencionar el apoyo mutuo y la comprensión.

Según Ramón Ortega Tallabs en su obra Crece: Valores para la vida (2000, pág. 16). "La familia es el lugar privilegiado para formar una afectividad equilibrada y sana, para crecer en amor y para trabajar con ánimo. Es una institución social encargada de reproducir el orden social y de asegurar la transmisión del patrimonio técnico-cultural a las sucesivas generaciones". En este grupo socializador primario se forjan una serie de valores y virtudes que ayudan a sus elementos a relacionarse para ayudar a la formación personal afectiva y emocional en el desarrollo de su vida diaria con los que los rodean.

\section{Tipos de amor}

Amor sentimental, romántico: es el amor por la pareja; se ama a otra persona, no tiene porqué haber razón; simplemente amor, esa otra persona nos dará felicidad por el simple hecho de amar y ser amado; nos protege, cuida y mima...; el amor por la pareja es de las mejores cosas que existen.

Amor fraternal: en su sentido estricto, es el afecto entre hermanos, aunque se extiende a otros parientes exceptuados los padres y adultos. Nace de un sentimiento profundo de gratitud y reconocimiento a la familia, por emociones que apuntan a la convivencia, la colaboración y la identificación de cada sujeto dentro de una estructura de parentesco. Lo mismo que el amor filial, y desde el punto de vista del psicoanálisis, el fraternal es sublimado, ya que está fundado en la interdicción del incesto.

Amor por los animales, principalmente se puede amar a la mascota; aunque también a todos los animales de nuestro alrededor, ellos son seres que también pueden ser agradecidos, y que se merecen todo nuestro amor.

Amor a los amigos; las personas necesitamos apoyo, confianza, ayuda, complicidad, ser sociales... por ello sentimos amor por los amigos; la amistad hace más fuertes a las personas.

Amor a todas las personas; por suerte hay gente que nos quiere a todos; porque todos somos humanos, hermanos, iguales; el amor al prójimo es necesario en nuestra sociedad, porqué hacer el mal si es mejor hacer elbien.

Amor por el deporte; se puede estar obsesionado con una actividad deportiva y quererla por encima de nosotros mismo; también es normal el amor a los colores de un equipo.

Amar a un dios o una deidad (devoción), puede surgir con el tiempo aunque normalmente se inculca en la educación de padres a hijos; amar al dios de tu religión. Básicamente el amor a dios es amar a las demás personas; todos los valores que se inculcan suelen ser positivos; aunque por desgracia muchas religiones se infestan del odio y la violencia que unos pocos profesan. 
El amor altruista; muy identificado en la frase 'Hay más amor en dar que en recibir'; ;inculcado en personas solidarias,...

El Amor y la familia

Hablar sobre el amor es arriesgado, todo un reto de investigación, lecturas, observación e introspección de quien habla sobre ello. Es un tema fascinante sobre el que se han escrito tantas cosas, algunas muy serias y otras algo banales, típicas, pero que sirven tanto como las serias, porque de todo se aprende y sobre todo de los puntos de vista de las personas que se arriesgan y tiene el valor de escribir sobre ello.

El Ser Humano desde que nace y, en general, el mundo depende mucho de este artículo de primera necesidad que llamamos "amor". Vivir sin amor, no es vivir, es padecer y a lo largo de la historia del hombre se ha evolucionado siempre de acuerdo con la premisa de que el amor es fundamental para la misma.

Se distinguen varios tipos de amor: amor al ser humano, amor filial, amor fraternal, amor paternal, amor a la Naturaleza, amor en la amistad, y el amor de Pareja. En este capítulo vamos a referirnos al amor de Pareja, puesto que nos metemos en la gran aventura que suponen las "Cosas de dos".

Como veremos a lo largo del capítulo, es imposible no amar. Aunque este toma las distintas formas y tiene infinitas versiones, todos sentimos este sentimiento que puede convertirse en la miel más jugosa y en la obsesión más reiterativa. El amor nos nutre y a su vez nos hace perder la cabeza. Basta recordar aquella vez que tuvimos aquel encuentro fortuito con aquella persona, y sentiremos esa mezcla vertiginosa de sensaciones. Es muy corriente encontrarnos con personas que tienen miedo a amar, esto les hace temerosa de vivir.

El amor es como una rosa, es fragante, colorida y tambiên tiene sus espinas. Pero, ipodemos evitar esta dulce fragancia solo por un posible pinchazo? Tenemos la firme convicción, que la atracción que sentimos cuando amamos es mucho más potente que la evitación del sentimiento de miedo. Por mucho que hallamos vivido innumerables desengaños, siempre escuchamos el latido de nuestro corazón y buscamos la calidez del contacto íntimo.

En esta primera đisertación que con humildad nos proponemos hacer para que llegue al alcance de estudiosos del tema o simplemente de aquellos que quieran informarse y ampliar sus puntos de vista, nos basamos en nuestra experiencia, en la observación en consulta, en nuestras lecturas y también en la experiencia que nos proporciona la vida. Las referencias bibliográficas sobre el tema son las obras de Buscaglia, Rougemont, Murueta y Hay, Fromm y Peck. También en revistas de divulgación terapéutica, cuya línea de información es holística, humanísticoexistencial y Gestáltica, es decir, es decir, corrientes que hablan del ser humano y sus sentimientos considerándole como indivisible en su parte física, psíquica y espiritual. Estamos convencidos de ello y por tanto no separamos ninguna de las partes sin considerar las dos restantes.

Asípues, comenzamos a hablar sobre el Amor como un sentimiento aprendido y que requiere en líneas generales cierta reciprocidad para que sea auténtico, y no como producto de una dependencia o adicción psíquica y emocional que a veces confundimos con el Amor. El amor es 
un sentimiento compartido, se siente amor por las personas que a su vez le aman a uno de alguna manera.

Para algunos el amor es un bello cuadro colorido. Para otras personas es la pieza musical más apasionante, $y$, para otros, la danza más estimulante. Cuando un persona está inmersa en este sentimiento, su vida desprende un reconocible perfume, se pierde, se embriaga, se entrega. Como decía Erick From, el amor es un arte. Nace de la inspiración y continúa en la creación. Si la creación se descuida, esta se pierde.

La reciprocidad y el aprendizaje son desde nuestro punto de vista, dos puntos básicos que definen al amor. El amor parte por el amor hacia uno mismo, las personas que no se aman son incapaces de amar de verdad. "Aquel que se ama a sí mismo, ama a los demás" No es el himno al narcisismo. Todo lo contrario, una persona ha de reconocer su propio sentimiento, si no lo sabrá ver en los demás.

Como dice Murueta (1999), el amor hace historia y también hace sentir como propios los sentimientos de la persona amada, de la queremos estar cerca, tendemos a escucharla y tendemos a manifestarle nuestro amor de muy diversas formas como veremos más adelante. La manifestación del amor por el otro, en el marco de la Pareja le sigue a conocimiento en profundidad del otro,

En muchas ocasiones, el amor ciega. Vemos en el otro cosas que no hay y como si fuésemos una proyectora, vemos en la otra persona la imagen más bonita que tenemos dentro. Por eso, enla relación de pareja tan importante como este sentimiento, es el conocimiento. Es cierto que donde hay química, hay física, y es igualmente necesario saber observar, para que al besar a una princesa o a un príncipe, no se convierta en rana. Cuántos de nosotros y nosotras hemos creído que por fin encontramos a la pareja de nuestra vida. Nos entregamos sin pensarlo dos veces a la locura fruto de la pasión y, de pronto, cual espejismo en el rumbo de la carretera en el calor del verano, todo se desvanece. Esto ocurre muy a menudo por ello el amor no solo debería ser ilusión.

Durante el enamoramiento una venda se pone en nuestros ojos con respecto a la objetividad en el conocimiento real del otro y nos sitúa en un mundo maravilloso sin problemas, en el que el otro se convierte en el príncipe o la princesa de nuestros sueños, creemos haber encontrado nuestra media naranja. Pero quizás, durante la fase de enamoramiento y descubrimiento, es mejor no tomar decisiones trascendentales sobre el futuro de tal relación. Sin embargo, es de ahí de donde parte la profundidad de la relación, en esos primeros momentos de amor romántico y por tanto no deben ser menospreciados, ya que ese mismo amor romántico se puede volver a vivir en sucesivos momentos en la vida en común de la Pareja. Siempre sabiendo, por supuesto, que son momentos y que luego se vuelve la vida cotidiana en la que es necesario puntualizar, dialogar, pactar, negociar y escuchar con respeto y amor, pero no precisamente romántico. El príncipe y la princesa se convierten en personas que funcionan en la vida y sobreviven a los problemas de la cotidianeidad y del estrés de la vida en el mundo occidental que es desde donde parten todas estas ideas.

La solidaridad, el compañerismo y el convertirnos en aliados es entonces cuando es un punto fundamental e intrínseco al amor de Pareja, evitando siempre los juicios de valor dando paso en 
todo caso a la crítica constructiva y siguiendo con el hecho de compartir y hacer propios los sentimientos del otro, así como el más profundo respeto a su idiosincrasia, hacia su libertad de expresión y hacia su persona de una manera integral, de totalidad.

No estamos de acuerdo con la frase de Mark Twain, "el amor es una cosa graciosa, primero produce un gran choque, luego terminamos llevándole a un museo". Si bien reconocemos que esto pasa en algunas ocasiones, no ocurre siempre. Sólo sucede cuando el aletargamiento pasivo invade a la pareja y cuando ésta no tiene ni ganas, ni fuerza, para escapar de los tentáculos de la monotonia y de la pesada rutina.

Vamos a hablar en este libro sobre el amor en la Pareja que es un tipo de amor diferente al paternal, filial, fraternal, de amistad o hacia el ser humano en general.

Hablaremos, también, de los virus que se inmiscuyen en la relación, propondremos algunos antídotos, $y$, trataremos de fortalecer la perspectiva de "cuando la apatía toca la puerta, el sano disfrute le habre, y no hay nadie afuera".

En la Pareja, cuando comienza el amor, esta en el aire el comenzar una vida juntos, lo cual hace imprescindible el conocimiento de quien es exactamente el otro, qué piensa y siente, cuales son sus aptitudes y sus aficiones.

Es importante captar desde donde procesa la información, si desde el pensamiento, desde la emoción o desde la visceralidad y si por tanto esa persona "encaja" bien en nuestra manera de ser y de vivir o si por el contrario simplemente ello pueda hacerse compatible, porque las personas pueden desarrollar compatibilidades siendo diferentes.

Pero esta compatibilidad no sigue la ley "del todo o nada". Una pareja puede encajar en algunas áreas y en otras no, puede que la compatibilidad se vea en incremente a lo largo de los meses y de los años, opuede verse duramente disminuida. Las personas aprendemos unos de lo otros. Esto supone que la pareja también aprende. Muchas veces en sus miembros se produce una simbiosis, que es el aprendizaje más profundo que dos ser humanos pueden tener. A éste concepto también le llamamos sinergia, y se produce cuando tenemos la sensación de estamos muy unidos y que nadie podrá con nosotros dos.

Es necesario distinguir las diferencias entre el enamoramiento y el amor. Es imprescindible tocar el fascinante tema de la Pasión que está unida intrínsecamente al amor de Pareja, sobre todo el los momentos de enamoramiento, pero también a lo largo de la vida, en momentos pasionales que pueden ocurrir y que es interesante favorecer ya que "alimentan" el amor, la sexualidad y la energía amorosa, y sobre todo la complicidad, la unión, la solidaridad y la complementariedad que cada uno aporta para que se pueda vivir toda una vida juntos, los dos.

En el enamoramiento todo está amplificado. La pasión, el cariño, y la atención a detalles. Esta fase de cortejo ocupa un espacio interno muy especial en las personas implicadas. También en estos momentos los perfiles del amor y la obsesión se desdibujan. Pasamos mucho tiempo rememorando el rostro de la persona que nos impacto y el paso del tiempo se nos puede dilatar cuando estamos frente al teléfono esperando su llamada. Es importantísimo reconocer que, este estadio no se mantiene durante toda la relación. De ser así, se convertiría en una relación insana, sin libertad, y con grandes dosis de dependencia. Tema del que hablaremos, también a lo largo de este capítulo. 
Cuando nace el amor en la Pareja, la persona es aceptada en nuestros ojos, oídos, tacto. Nos tiene que agradar su perfume natural y su buen gusto. Cualquier incomodidad que surja de alguno de estos canales puede ser un inconveniente profundo en la evolución del amor entre dos. Es importante amar desde todos nuestro sistemas sensoriales. Es importante para la sexualidad y para la aceptación en su integridad del otro. Se ama el cuerpo, se ama la mente y se ama la espiritualidad.

El deseo sexual en una relación de Pareja, forma parte del amor, ya es parte intrinseca de la comunicación no verbal y del amor en la Pareja. La ausencia de deseo sexual en el amor de pareja es un fuerte síntoma de que algo esta pasando, grave para la futura continuidad de tal amory que requiere puntualizaciones y sentarse a dialogar.

En la Pareja, el deseo sexual es fundamental y es ahí donde se dicen las cosas más profundas y a la vez tiernas a veces con palabras, y a veces sin ellas. También es ahí donde la Pareja eyoluciona hacia formas de actuar en su sexualidad a veces impensables en los primeros momentos, pero tal evolución es importante de cara a no llegar a algo muy en común en muchas parejas, y que también mata el Amor y es el aburrimiento.

La novedad nutre al deseo sexual. Hacer el amor en distintos lugares con distintas posturas corporales es una actitud sana y nutricia que evita la monotonía y la rutina. Como ambos llevan invariablemente al aburrimiento sexual, lo mejor es hacer que el goce sea más profundo variando la forma de obtenerlo. Centrase en el dar placer al otro también es muy recomendado en este punto. La exploración del cuerpo del otro, se hace necesaria y es una aventura sin fin que a su vez es uno de los ejercicios saludables de Pareja que recomendaremos.

Es punto importante en el amor, también el respeto al territorio propio del otro. El amor no es posesión sino independencia y se comparte aquello que pone en una situación cómođa a los dos por igual. En el Amor y la relación de Pareja siempre decimos que hay tres vidas, la de uno, la del otro y la que comparten y tienen en común. Esimportante respetar las tres vidas por parte de los dos, y en todo caso mediante el dialogo y en general la comunicación compartir las que son propias en la medida en que uno se siente cómodo con ello.

El amor es respeto, educación y elegancia en las formas. La ausencia de cualquiera de estas tres premisas mata el amor o lo destruye.

El amor es emprender, es divertirse y reír, es dialogar y reñir, es pactar y negociar, y también se expresa mediante la comunicación no verbal, en los gestos, las miradas, las caricias y el deseo sexual.

El amor evoluciona a la vez que las personas que se aman y ese amor si es producto de la evolución conjunta, se hace cada vez más solidario y más profundo y convierte a las personas en seres que, juntos, salvan las dificultades que continuamente pueden aparecer en una convivencia o vida en común.

El amor de Pareja hace que se funde la familia, y que de esa unión puedan llegar otros seres, los hijos, que pasaran a formar parte de la vida de los dos. Cuando es producto del amor y de un consenso entre los dos, la llegada de los hijos enriquece el mundo de las "Cosas de dos". 
La familia como concepto está cambiando. En la actualidad tenemos una san igualdad laboral en hombres y mujeres. Esto significa que hay variaciones entro el seno e la misma. La pareja en la familia se está aclimatando. Por tendencia social, la mujer era quien atendía las labores domésticas (cuidado de hijos, atención por la casa, etc.), una labor tan o más extenuanie como el trabajo del marido. Ahora, y cada vez más, ambos trabajan, ambos ingresan dinero, y ambos tienen que atender todas la necesidades familiares. Esto puede ser un punto de fricción en la relación. Tenemos un reto, ir más allá de lo que nos dicta nuestro aprendizaje familiar (lo que vivimos con nuestros padres), para tener otro tipo de actitudes. Especialmente el hombre tie he que cambiar tendencias obsoletas producto de otras épocas útiles para otros contextos sociales

El amor no es igual a medida que pasa el tiempo y el amor de pareja a los 20 años no es igual que a los 40 , éste a su vez no es el mismo que a los 60 y tampoco que a los 80 . Hablaremos del amor durante el ciclo de la vida y como se configura a través de los años tanto por la edad física, como por la experiencia psíquica en el manejo de los sentimientos y por la evolucion producto de las experiencias vividas.

No hay nada más apasionante y difícil de hacer que hablar sobre el amor con todo lo significa: cortejo, respeto, pasión, deseo sexual, cariño, territorio, compartirse, entrega, intinidad, aceptación, objetivos comunes, evolución conjunta, etc. No hay nada como el amor, es la fut rza más potente que nos nutre. Pero como dice el dicho, "de nada sirve un coche potente que care ce de freno", el amor también significa detenerse, echar un vistazo, y apıenđer de lo que conjuntamente se está creando. En este capítulo usted verá muchas claves para vivir sanamey te el amor en una relación de pareja.

\section{Estrategias de amor en la familia}

Involucrarse en las actividades de los demás

- Platicar sobre las cosas que pueden hacer juntos.

- En dónde necesito que me ayuden.

- Ayudar a quien veo me necesita.

Urbanidad

- Darbuenos días.

- Cómo estas, cómo te sientes, cómo te fue en la escuela-trabajo.

- Preocuparse por el otro (abrazar a mamá).

\section{Confiar}

- Ayudarlos a conocerse (limitaciones- cualidades).

- Aplaudir sus logros, no echar en cara sus malos actos.

- Creer en la persona- aunque todolo culpe.

Disciplina

- Buscar el bien (no momentáneo).

- Exigir responsabilidad, compromiso en las actividades.

- Ayudar a perfeccionarse.
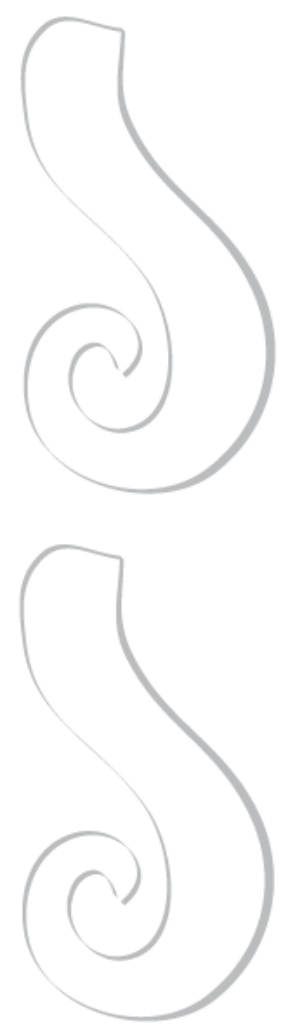


\section{Taller de familias \#1.}

Objetivo general: Impulsar el valor del amor y la libertad en las familias de Ayahualulco, Veracruz.

Tema: Libertad.

Objetivo: Clarificar el concepto de la libertad en las familias.

Máximo 20 familias.

\section{Inducción}

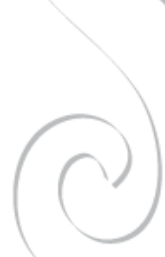

1. Realizarán un dibujo de su familia, un símbolo que la identifique y un valor que sea importante para ellos.

2. Formar equipos de familias y que entre ellos se expliquen sus simbolos, familia y yalores.

3. Retroalimentación.

\section{Desarrollo}

1. Concepto de libertad.

2. Autores que hablan de la libertad.

3. La libertad y la familia.

4. Estrategias de libertad en la familia.

5. Retroalimentación de las estrategias entre las familias en su contexto particular.

\section{Actividad}

1. Cada familia deberá escoger una estrategia de libertad dentro de su familia, explicarla y hacer un compromiso.

2. Escribir el compromiso o estrategia en papel y pedirles que la peguen en sus casas.

\section{Material}

1. Hojas tamaño carta (una para cada familia).

2. Colores, crayolas o plumones.

3. Laptop.

4. Cartulinas.

5. Dulces.

6. Aula con sillas.

7. Un escritorio para laptopy cañón.

\section{Taller de familias \#2.}

Objetivo general: Impulsar el valor del amor y la libertad en las familias de Ayahualulco, Veracruz.

Tema: Amor.

Objetivo: Clarificar el concepto de la amor en las familias.

Máximo 20 familias.

Inducción

1. Proponer a los participantes que se den un abrazo afectuoso como manifestación de amor. 
Desarrollo

1. Concepto de amor.

2. Autores que hablan de amor.

3. Autores que hablan de amor.

4. El amor en la familia.

5. Estrategias de amor y familia.

6. Retroalimentación de las estrategias entre las familias en su contexto particular.

Actividad

1. Los participantes escribirán una reflexión, poema o dedicatoria hacia su familia relacionado con el tema visto.

2. Compartir lo escrito con su familia.

3. Realizar un mural con los dibujos de su familia o compromisos.

Material

1. Laptop.

2. Cañón.

3. Hojas tamaño carta.

4. Colores, crayones o plumones.

5. Dulces.

6. Aula con sillas.

7. Un escritorio. 

ANEXOS II
Universidad la Salle Pachuca
Fortalecimiento de la unión familiar desde el amor y la libertad en la comunidad de Ayahualulco, Veracruz. Semi-estructurada para padres.
Objetivo: Investigar el fenómeno de la unión familiar desde el amor y libertad. Instrucciones: Subrayar la respuesta que considere correcta.

\section{1. ¿Cuál es su nombre?}
2. Edad:
a. Menos de 15. b. Entre 15-20. c. Entre 20-25. d. Entre 25-30. e. Entre30-35 f. Entre 35-40.
g. Entre 40-45. h. Entre 45-50. i. Más de 50.

3. Un valor es:

a. Saber cómo nos portamos.

b. Cualidad que permite a probar el valor ético o estético de las cosas dignas de aprecio.

c. Ajeno a la moral. d. Otro ¿Cuál?

4. La familia es:

a. Asegura la economía de sus miembros, mantener a los hijos.

b. Espacio de afecto donde se lucha por el bienestar de todos y la transmisión de valores.

c. Núcleo social donde se generan problemas y faltan valores.

d. Otro ¿Cuál?

5. Subraya los dos valores más importantes para la familia.
a. Amor b. Libertad c. Participación
d. Asertividad
e. Justicia
f. Comp

h. Otro ¿Cuál?

6. La unión familiar es:

a. Participación de toda la familia para fomentar valores.

b. Que cada quien esté por su lado.

c. Convivencia entre los miembros y sólo los padres toman las decisiones.

d. Otro ¿Cuál?

7. La familia es importante porque:

a. Regañan a los más pequeños.

b. Conserva y transmite valores importantes.

c. Porque es unida y se apoyan en todo momento. d. Otro. ¿Cuál?

8. Los padres son los responsables de transmitir los valores a los hijos: ¿Por qué?
a. Si.
b. No.
c. No sé.

9. ¿Qué papel toma la escuela en esta enseñanza de valores?

a. Ayuda a la familia a la educación en valores.

b. Nos enseñan valores pero no los practicamos.

c. No existe la educación en valores.

d. Otro. ¿Cuál?
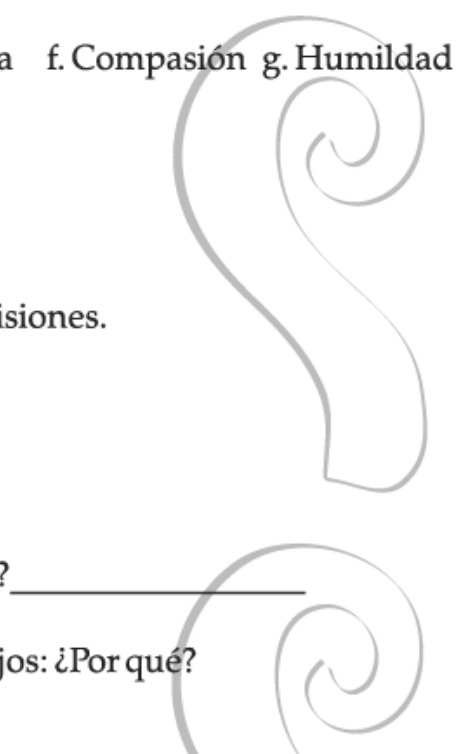
10. El problema actual más común de la familia es:

a. Violencia intrafamiliar.

b. Indiferencia, apatía y falta de los valores.

c. Económico.

d. Otro. ¿Cuál?

11. ¿Cómo se resolverían estos problemas?

a. Fomentando la educación en valores.

b. Seguir peleando y no dejarse.

c. Conviviendo más en familia.

d. Otro. ¿Cuál?

12. Actividades que favorecen la unión de la familia:

a. Tomar juntos las decisiones y participar juntos en actividades.

b. Irse cada quien por su lado.

c. Fomentar valores juntos.

d. Otro. ¿Cuál?

13. ¿Suele platicar del valor del amor con su familia?
a. Si.
b. No.
c. No sé.

14. ¿Le resulta difícil platicar del amor con el resto de su familia?
a. Si.
b. No.
c. Un Poco.

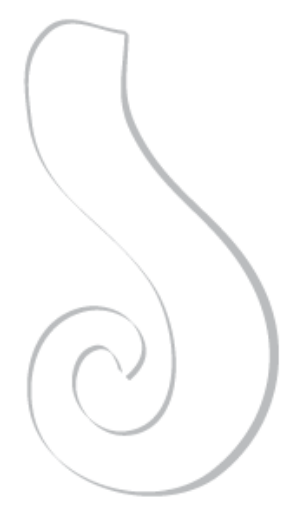

15. ¿Le gusta realizar actividades junto con su familia? a. Si. ¿Cuál?

b. No.

16. ¿Le gusta la práctica de valores con su familia?
a. Si.
b. No.
c. No me interesa ese tema.

17. ¿Qué propondría para una mejor unión familiar?

a. Menos problemas y conflictos.

b. Fomentar y enseñar más los valores.

c. Otro. ¿Cuál?

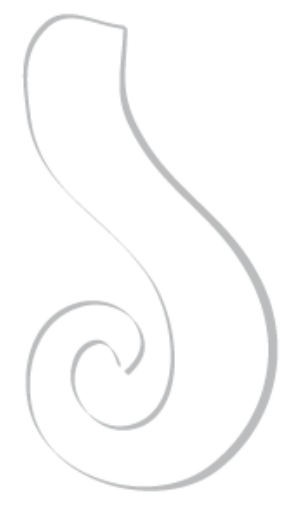

18. Cree que en su familia se práctica la libertad
a.Si.
b. No.
c. No sé.
d. Aveces

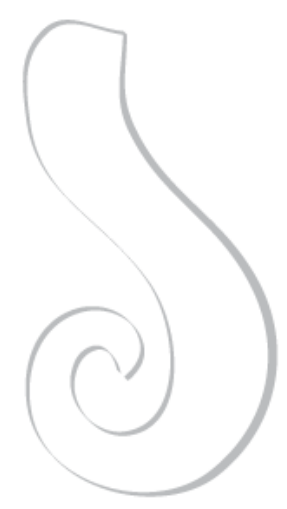

19. ¿Qué valor practican más en su familia?

a. Amor b. Libertad c. Participación d. Asertividad e. Justicia f.Compasión

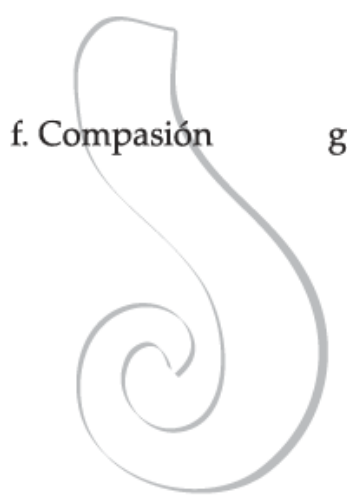
Humildad h. Otro ¿Cuál? 
Universidad la Salle Pachuca

Fortalecimiento de la unión familiar desde el amor y la libertad en la comunidad de Ayahualulco, Veracruz. Semi-estructurada para hijos.

Objetivo: Investigar el fenómeno de la unión familiar desde el amor y libertad.

Instrucciones: Subrayar la respuesta que considere correcta.

\section{1. ¿Cuál es tu nombre?}

2. Edad:

a. Entre10-15. b. Entre15-20. c. Entre 20-25. d. Entre 25-30.

3. Un valor es:

a. Saber cómo nos portamos.

b. Cualidad que aprueba el valor de las cosas.

c. Ajeno al bien.

4. La familia es:

a. La que mantiene a los hijos, les da de comer.

b. Espacio de afecto donde se lucha por el bienestar de todos y transmisión de valores.

c. Núcleo social donde se generan problemas y faltan valores.

5. Subraya los dos valores más importantes para la familia.
a. Amo
b. Libertad.
c. Participación.
d. Asertividad.
e. Justicia.

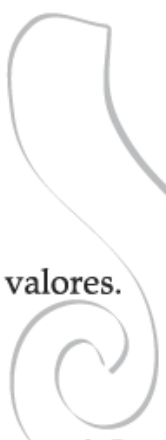

g. Humildad. h. Otro ¿Cuál?

6. La unión familiar es:

a. Participación de toda la familia para promover valores.

b. Que cada quien este por su lado.

c. Convivencia entre los miembros y solo los padres toman las decisiones.

7. La familia es importante porque:

a. Regañan a los hijos.

b. Conserva y transmite valores importantes.

c. Porque es unida y se apoyan en todo momento.

d. Otro. ¿Cuál?

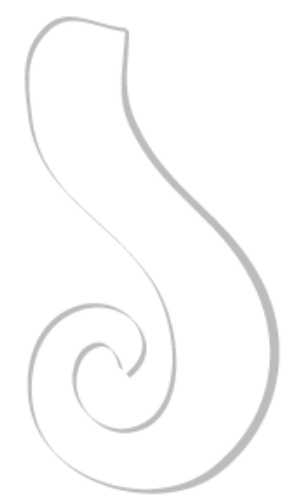

8. ¿Qué es lo que los hijos deben hacer para continuar los valores de sus papás?

a. Practicarlos y transmitirlos a otros.

b. No tomar en cuenta lo que mis papás me enseñan.

c. Practicarlos sólo cuando me conviene.

9. ¿Qué papel toma la escuela en esta enseñanza de valores?

a. Ayuda a la familia a la educación en valores.

b. Nos enseñan valores pero no los practicamos.

c. No existe la educación en valores.

d. Otro. ¿Cuál?

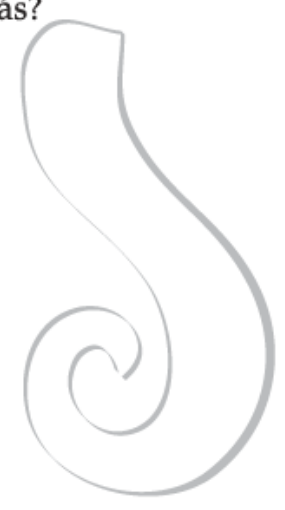


10. El problema actual más común de tu familia es:
a. Violencia intrafamiliar.
b. Indiferencia, apatía y falta de los valores.
d. Otro. ¿Cuál?
11. ¿Cómo se resolverían estos problemas?
a. Fomentando la educación en valores.
b. Seguir peleando y no dejarse.
c. Conviviendo más en familia.
d. Otro. ¿Cuál?

12. Actividades que favorecen la unión de la familia:

a. Tomar juntos las decisiones y participar juntos en actividades. b. Irse cada quien por su lado.

c. Fomentar valores juntos.

d. Otro. ¿Cuál?

13. ¿Sueles platicar del valor del amor con su familia?
a. Si.
b. No.
c. No me interesa ese tema.

14. ¿Te resulta difícil platicar del amor con el resto de su familia?
a. Si.
b. No.
c. Un Poco.

15. ¿Te gusta realizar actividades junto con su familia? a. Si. ¿Cuál?

b. No.

16. ¿Te gusta la práctica de valores con su familia?
a.Si.
b. No.
c. No me interesa ese tema.

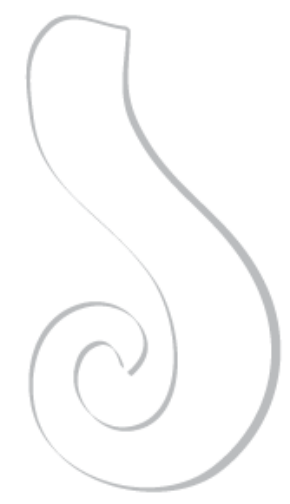

17. ¿Qué propondrías para una mejor unión familiar? a. Menos problemas y conflictos. b. Fomentar y enseñar más los valores. c. Otro. ¿Cuál?

18. Cree que en tu familia se práctica la libertad
a. Si.
b. No.
c. No sé.

19. ¿Qué valor practican más en su familia?
a. Amor.
b. Libertad.
c. Participación.

d. Asertividad. g. Humildad. h. Otro ¿Cuál?

20. ¿Has puesto en práctica los valores en tu familia y fuera de ella?

e. Justicia.

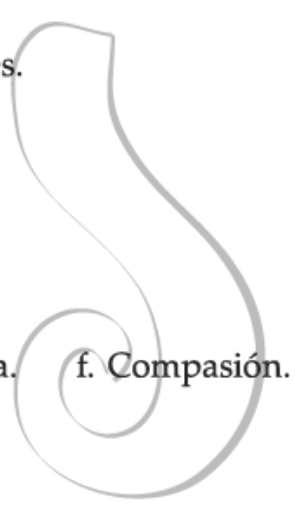
a.Si. ¿En dónde?

b. No.

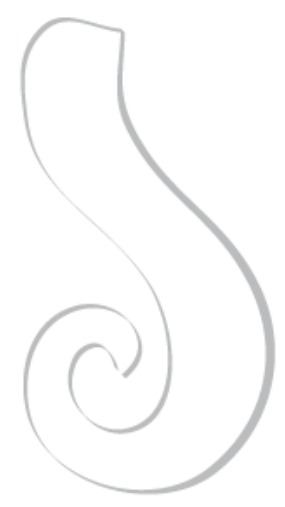




\section{0@ Universidad la Salle Pachuca ص@ \\ Fortalecimiento de la unión familiar desde el amor y la libertad en la comunidad de Ayahualulco, Veracruz.}

Objetivo: Investigar el fenómeno de la unión familiar desde el amor y libertad.

Indicaciones: 1. Mencione sus datos personales, (nombre, edad, lugar donde trabaja, lugar donde nació entre otros).

2. Narre una experiencia o suceso en donde el amor haya destacado o intervenido en la unión de su familia.

a) ¿Cuál fue el hecho?

b) ¿Cuándo pasó?

c) ¿Por qué pasó?

d) ¿Quién hizo que pasara?

e) ¿Cómo pasó?

f) ¿Dónde pasó?

g) ¿Cuáles fueron los resultados?

h) ¿Cuáles fueron las motivaciones?

3. Narre cómo lo resolvió y algunos aprendizajes a partir de este suceso

\begin{tabular}{|l|}
\hline \\
\hline \\
\hline \\
\hline \\
\hline \\
\hline \\
\hline \\
\hline \\
\hline \\
\hline
\end{tabular}

iGracias por su apoyo! 


\section{0@ Universidad la Salle Pachuca ص@ \\ Fortalecimiento de la unión familiar desde el amor y la libertad en la comunidad de Ayahualulco, Veracruz.}

Objetivo: Investigar el fenómeno de la unión familiar desde el amor y libertad.

Indicaciones: 1 . Mencione sus datos personales, (nombre, edad, lugar donde trabaja, lugar donde nació entre otros).

2. Narre una experiencia o suceso en donde la libertad haya destacado o intervenido en la unión de su familia.

a) ¿Cuál fue el hecho?

b) ¿Cuándo pasó?

c) ¿Por qué pasó?

d) ¿Quién hizo que pasara?

e) ¿Cómo pasó?

f) ¿Dónde pasó?

g) ¿Cuáles fueron los resultados?

h) ¿Cuáles fueron las motivaciones?

3. Narre cómo lo resolvió y algunos aprendizajes a partir de este suceso

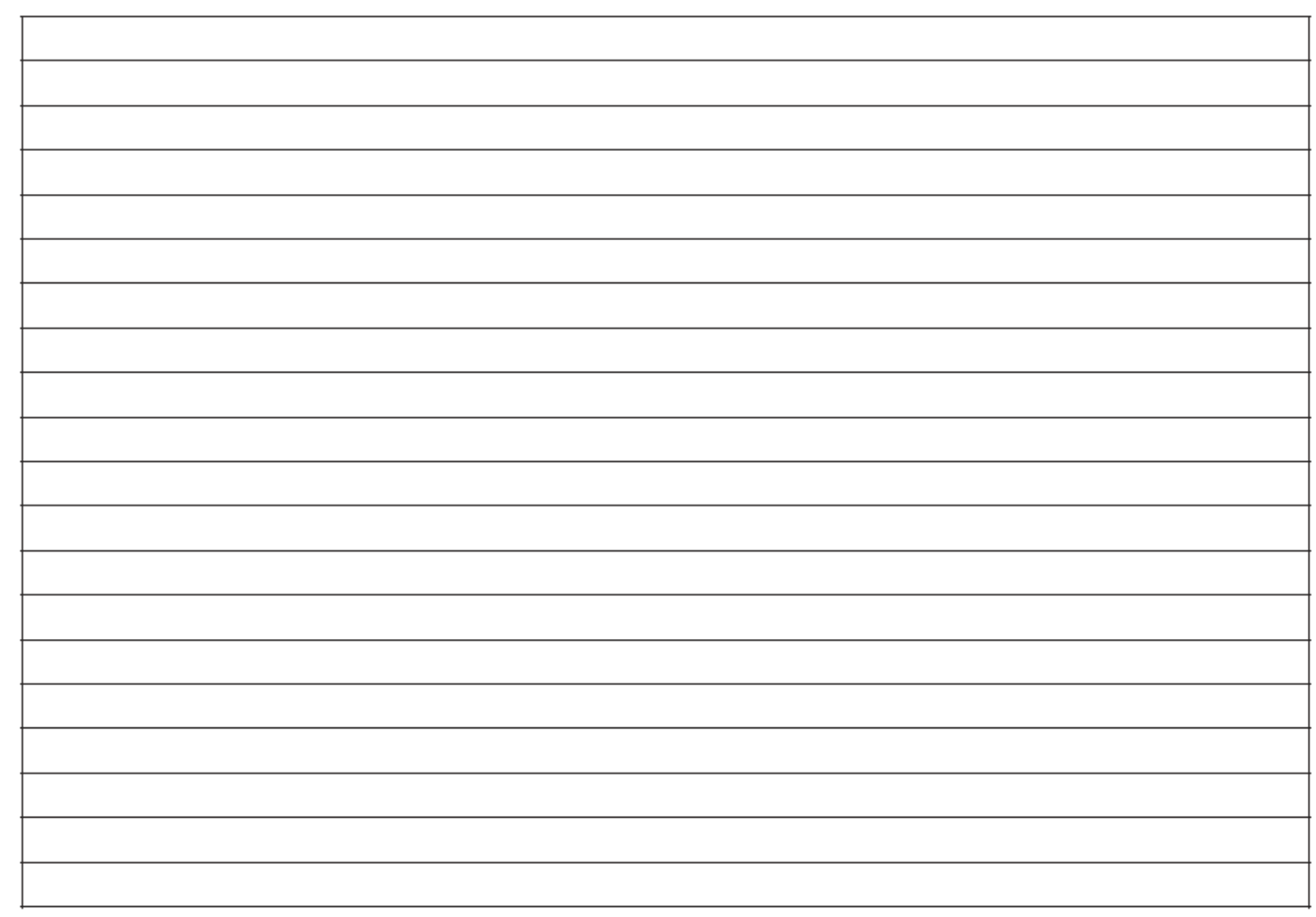

iGracias por su apoyo! $(\bullet$ 


\section{Análisis de la historia de vida ○@}

Datos personales

\begin{tabular}{|l|l|}
\hline Nombre: & \\
\hline Lugar: & \\
\hline Actividad realizada & \\
\hline
\end{tabular}

Estructura del relato

\begin{tabular}{|l|}
\hline 1. \\
\hline 2. \\
\hline 3. \\
\hline 4. \\
\hline 5. \\
\hline 6. \\
\hline
\end{tabular}

Datos importantes

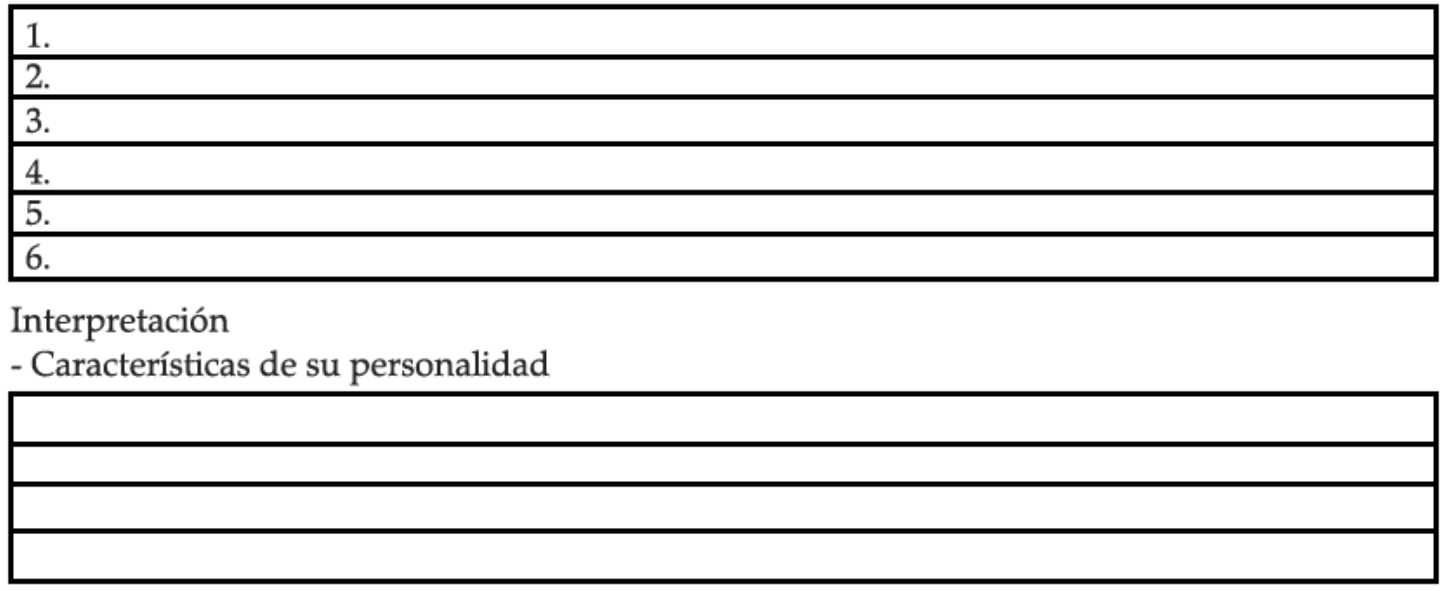

- Estados de ánimo y emociones desarrolladas

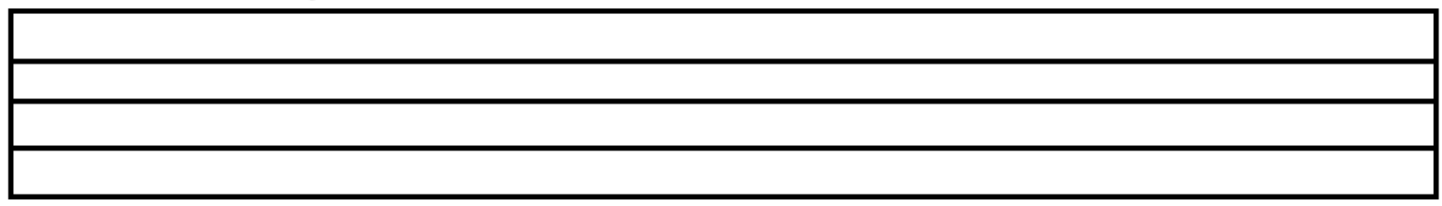

- Aprendizajes de vida

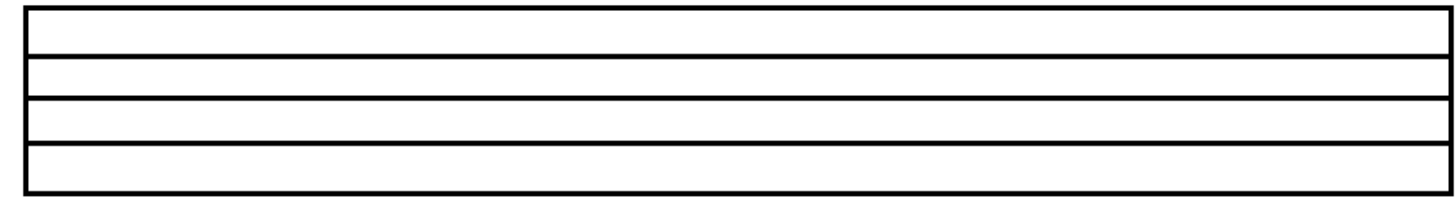

- ¿Para qué tipo de investigación utilizarías para esta narración?

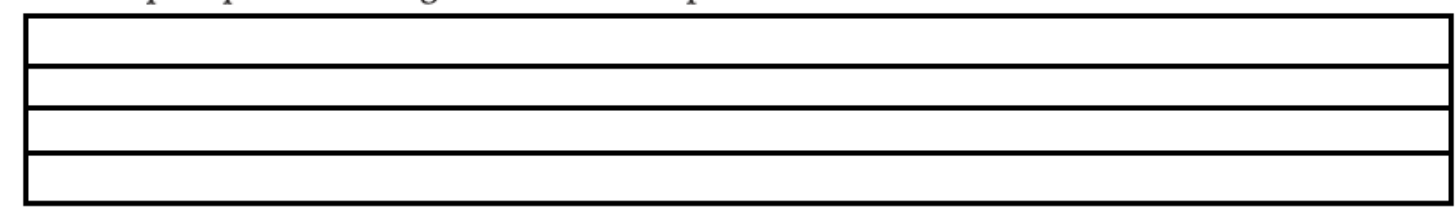




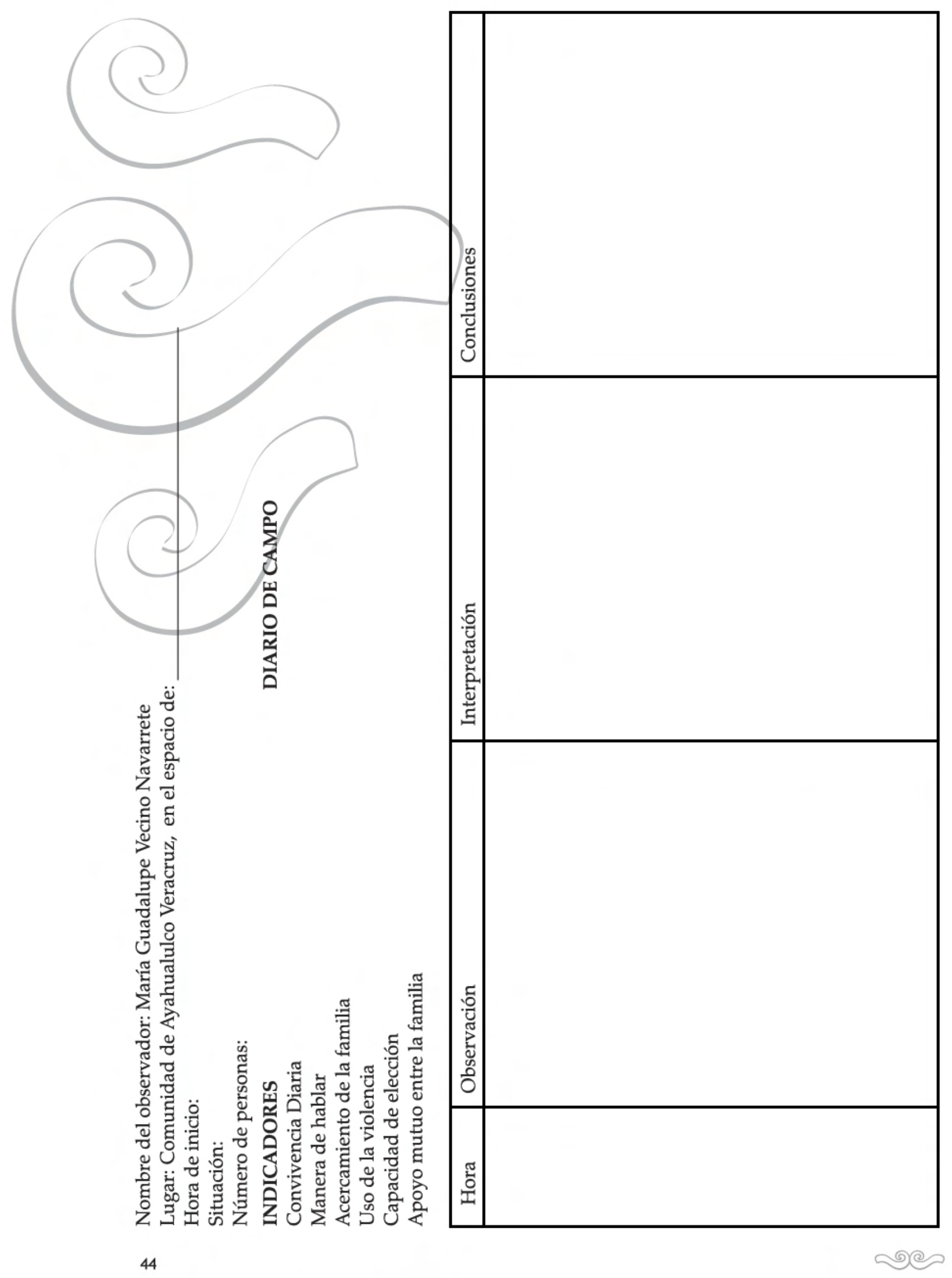



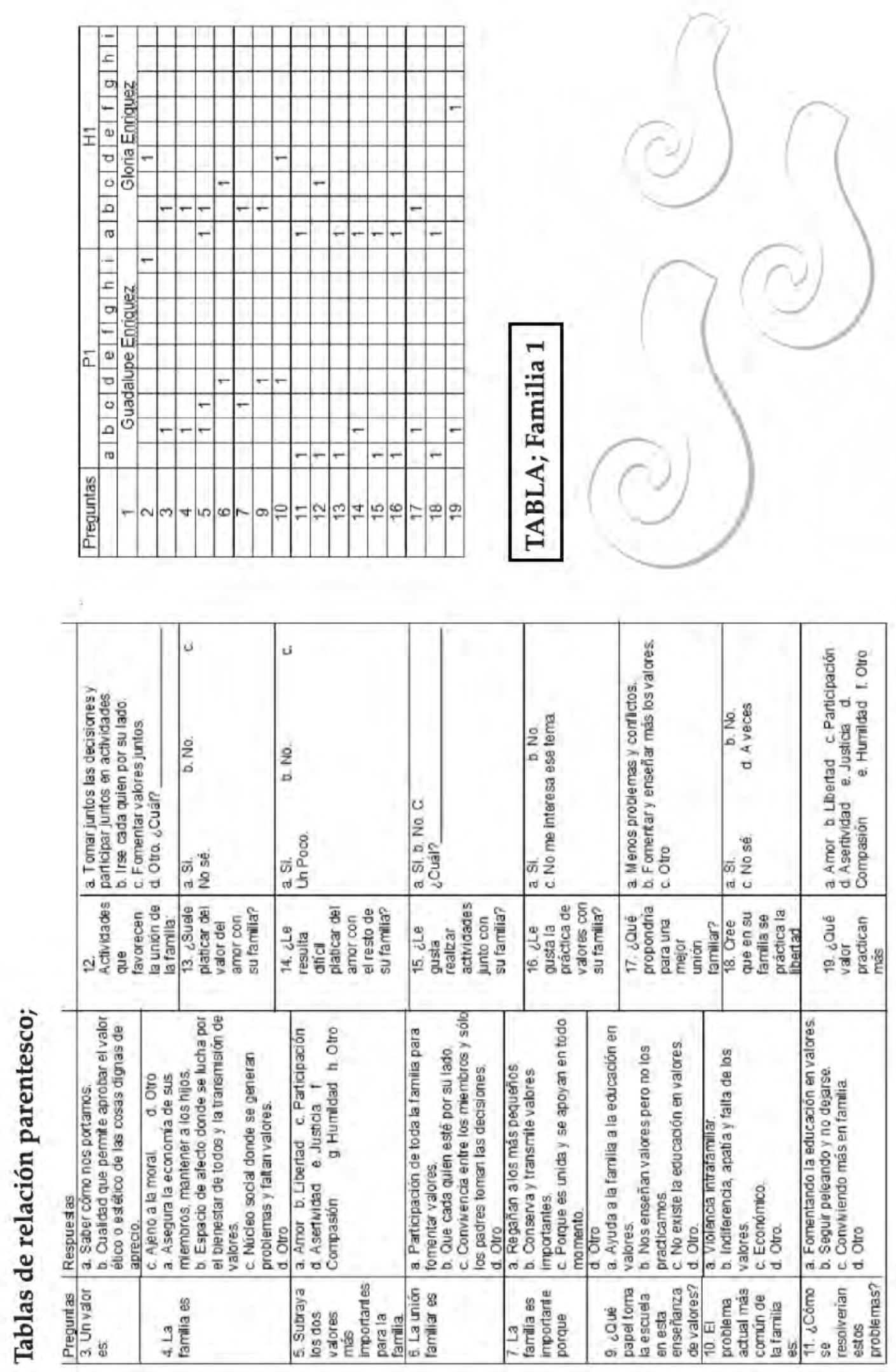

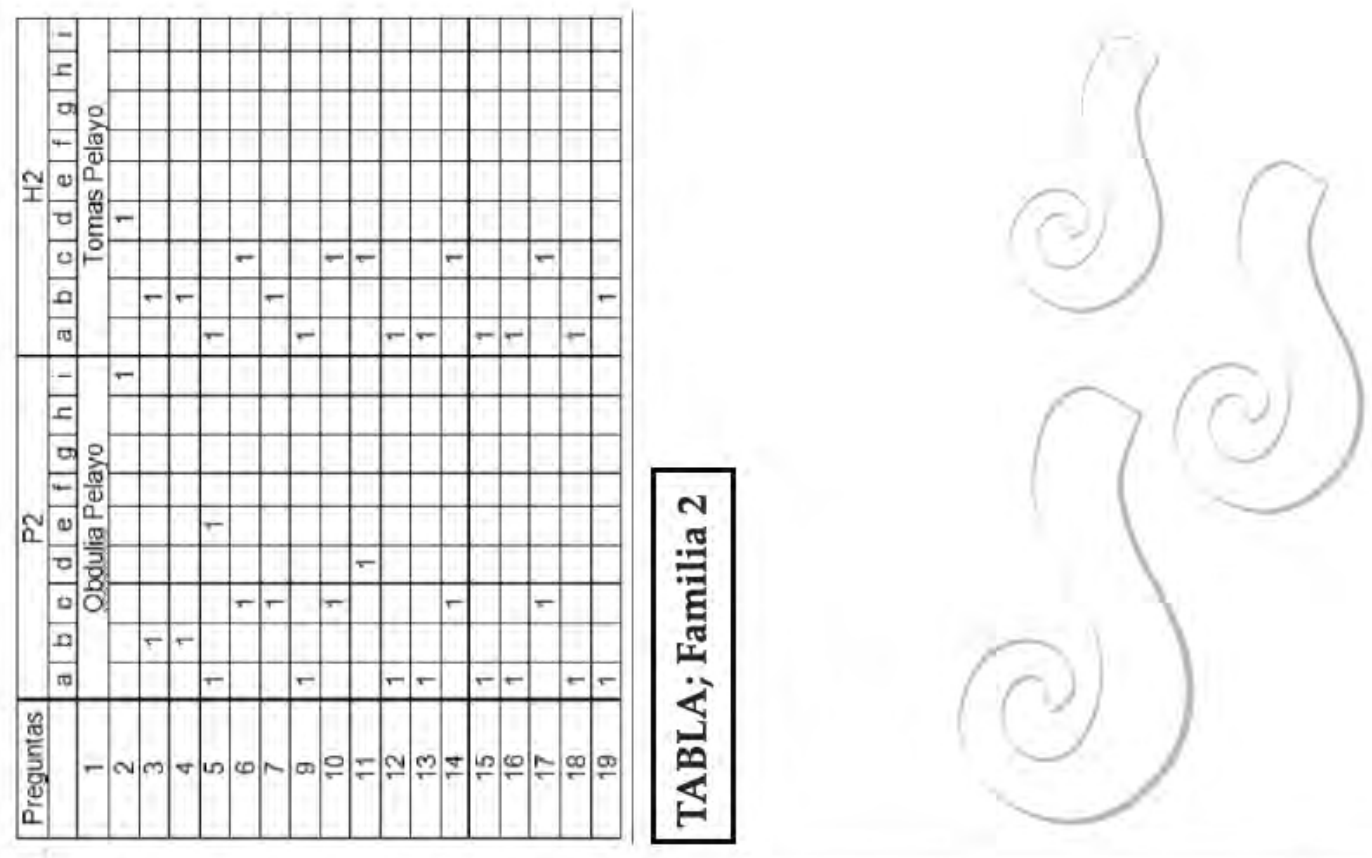

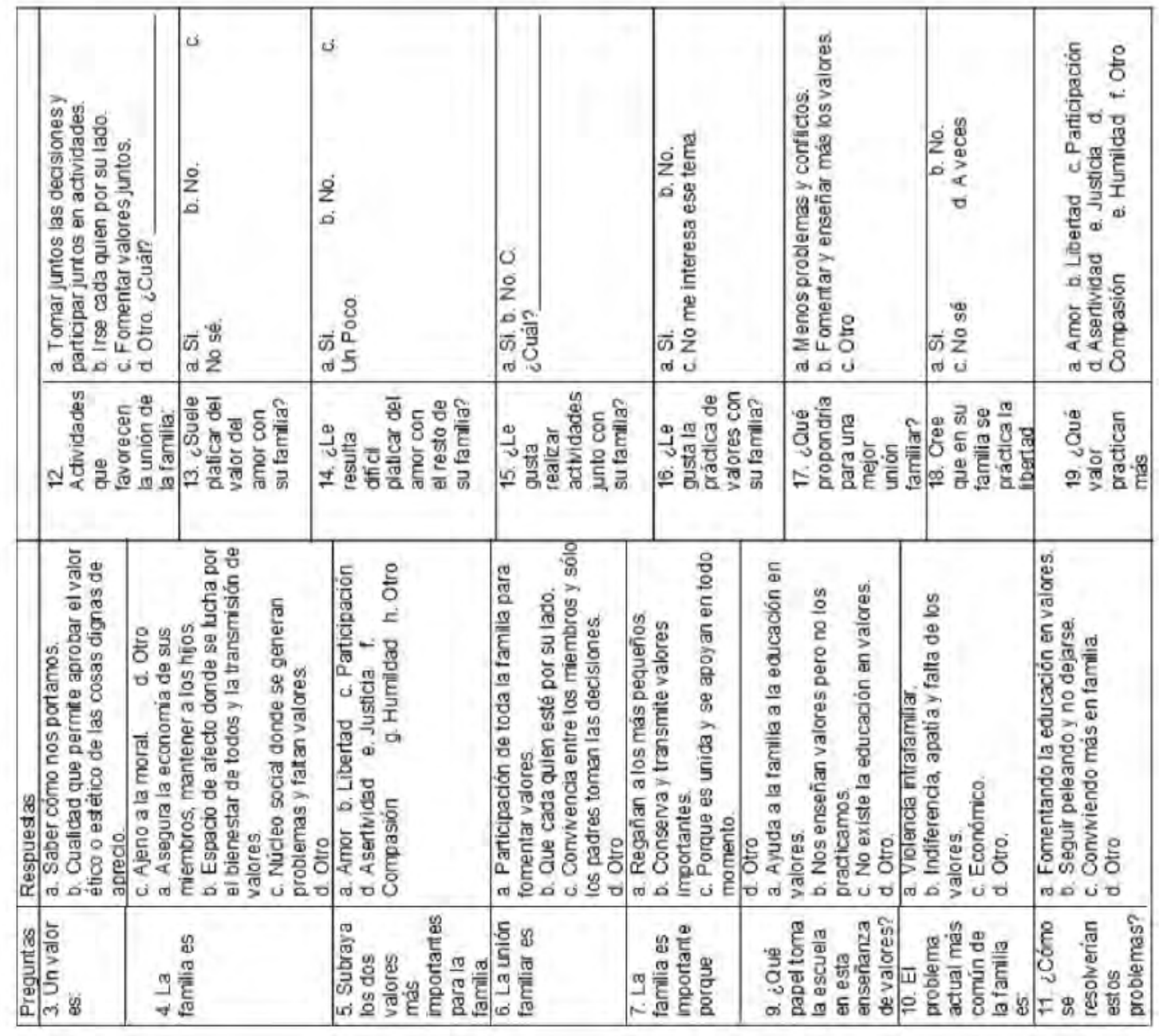



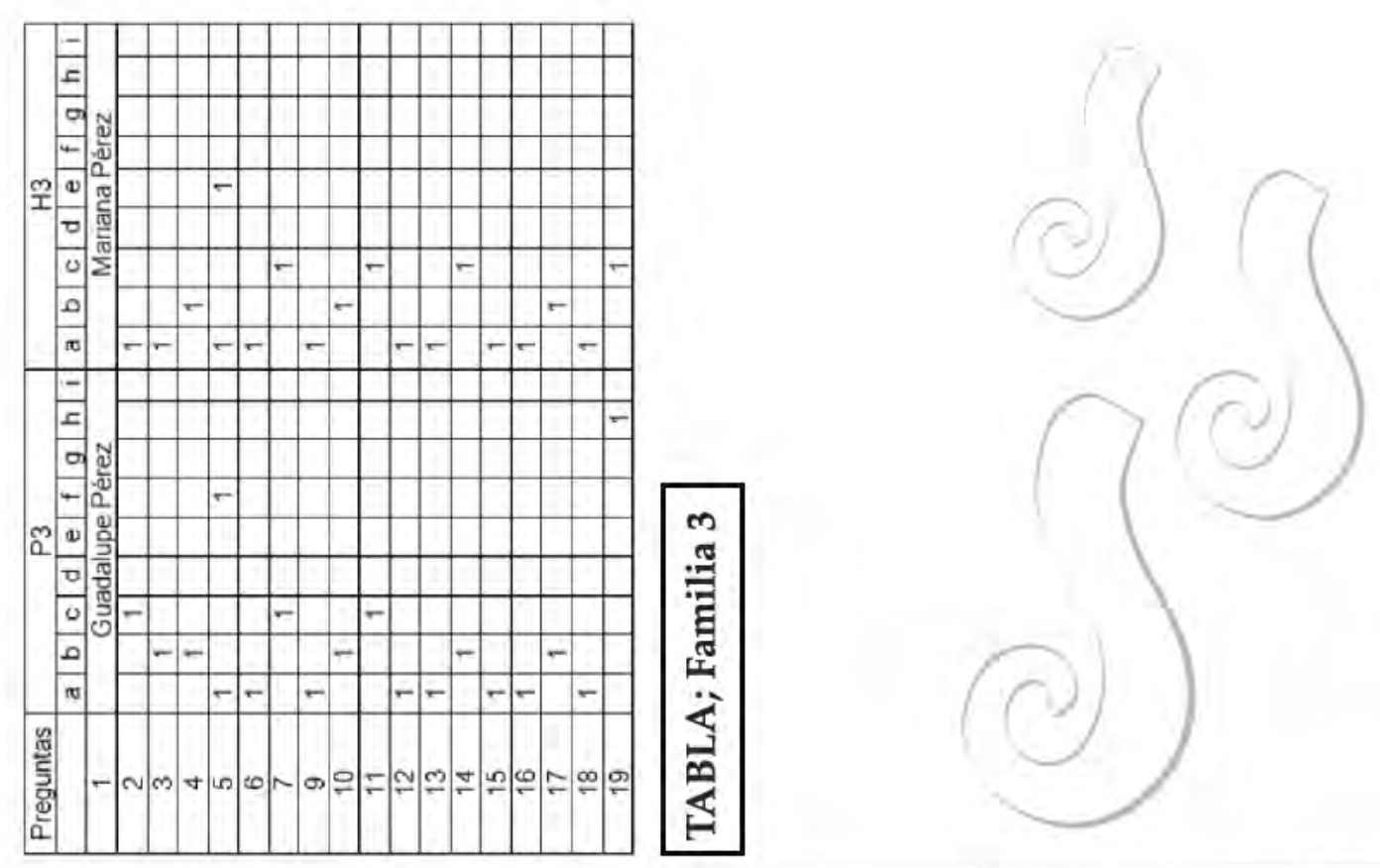

\begin{tabular}{|c|c|c|c|c|c|c|c|c|}
\hline \multicolumn{2}{|c|}{ 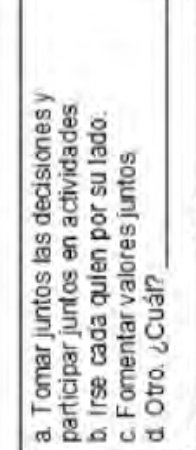 } & 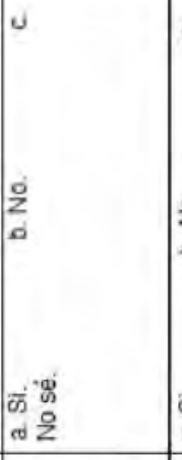 & 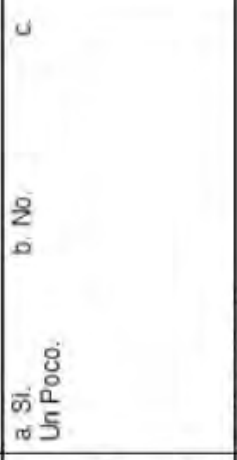 & 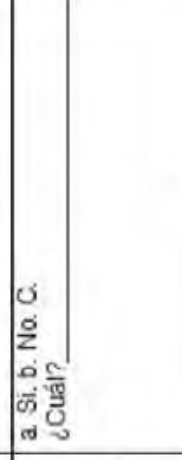 & 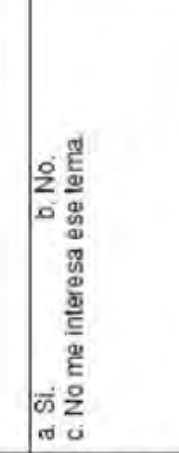 & 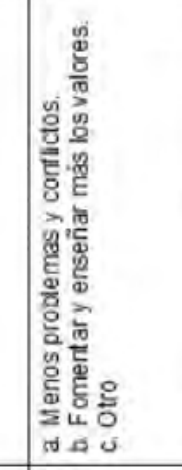 & 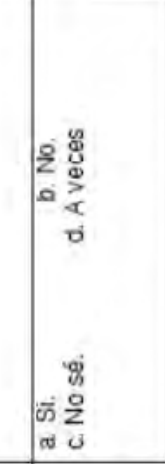 & 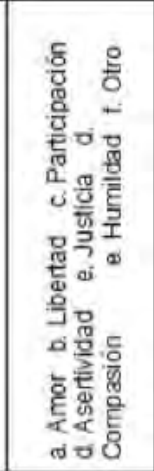 \\
\hline \multicolumn{2}{|c|}{ 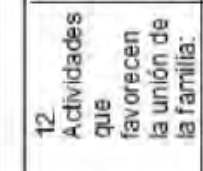 } & 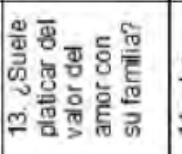 & 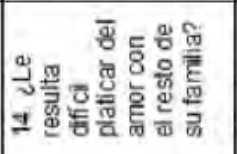 & 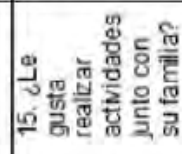 & 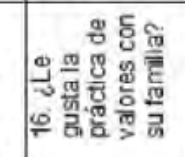 & 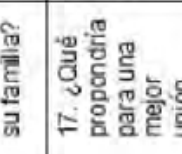 & 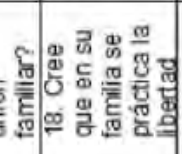 & 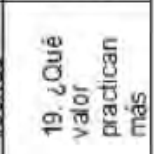 \\
\hline 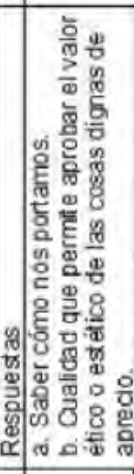 & 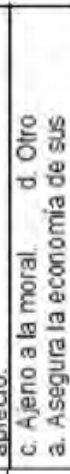 & 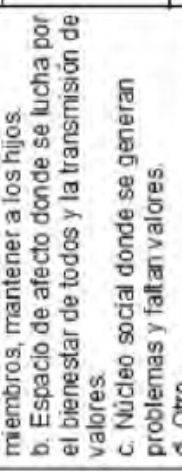 & 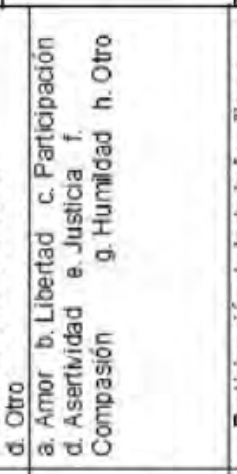 & 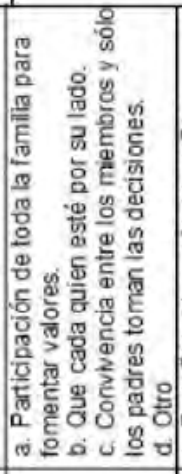 & 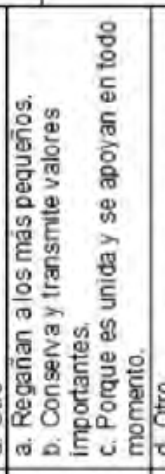 & 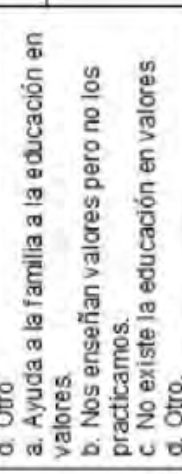 & 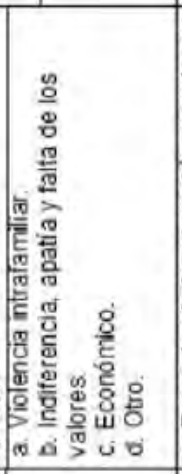 & 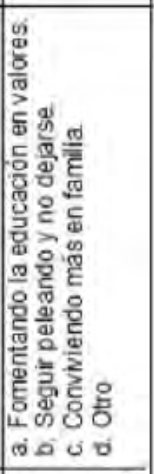 \\
\hline 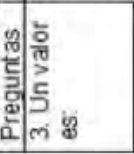 & & & 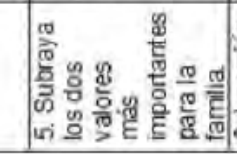 & 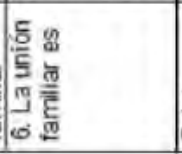 & 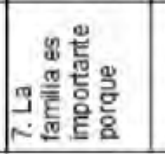 & 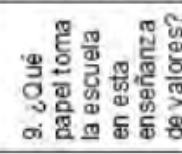 & 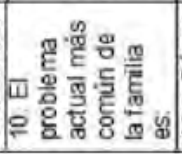 & 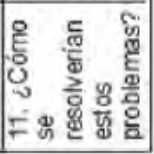 \\
\hline
\end{tabular}




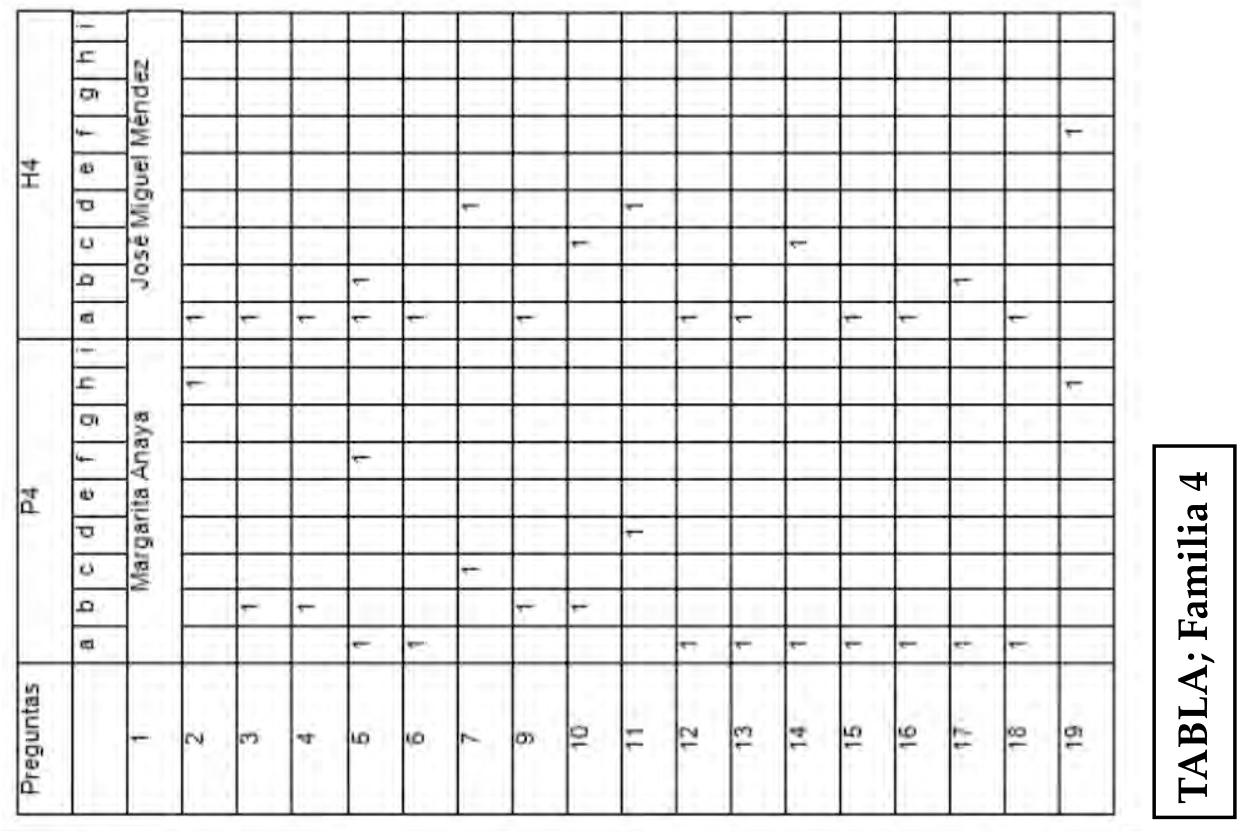

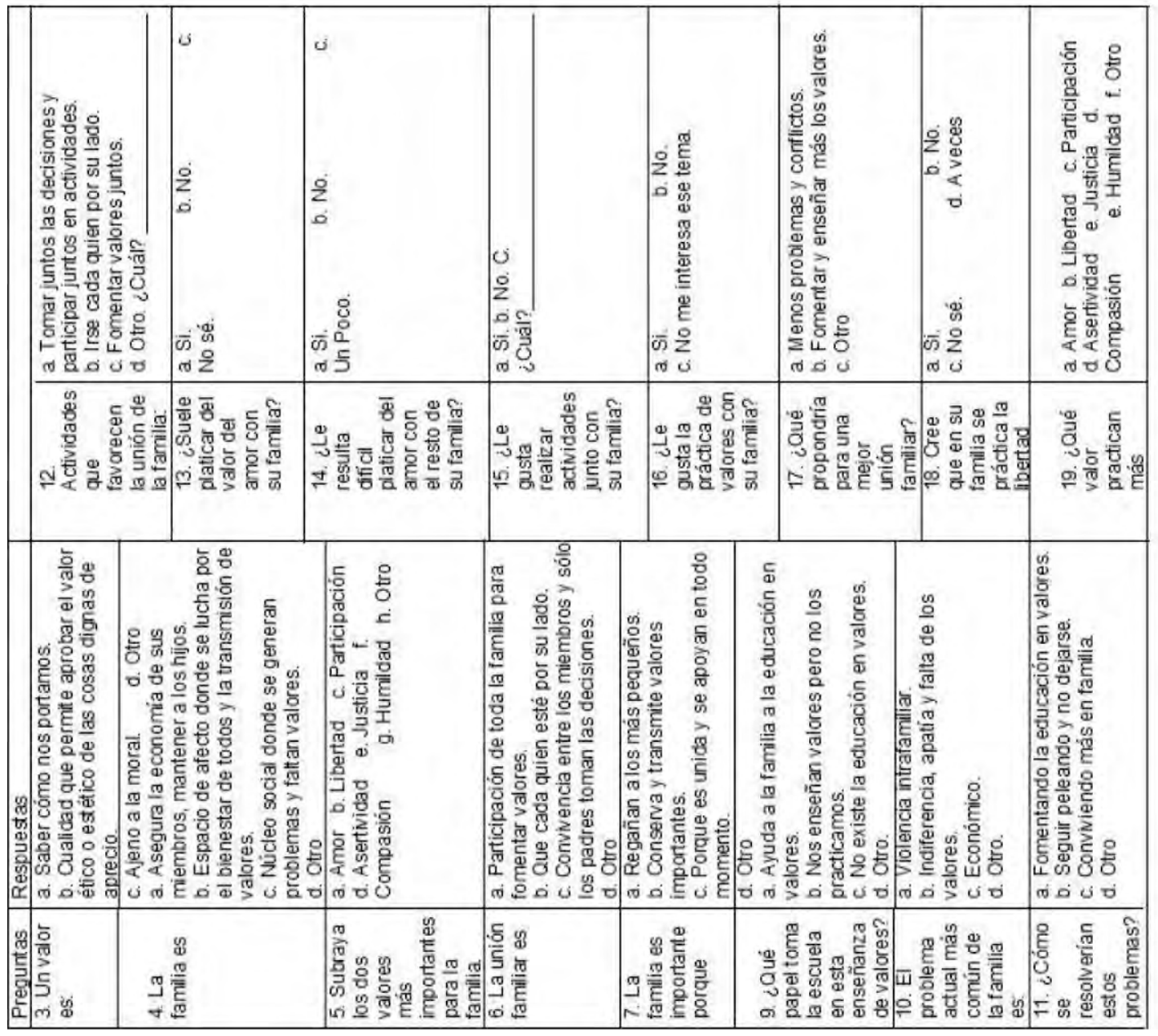



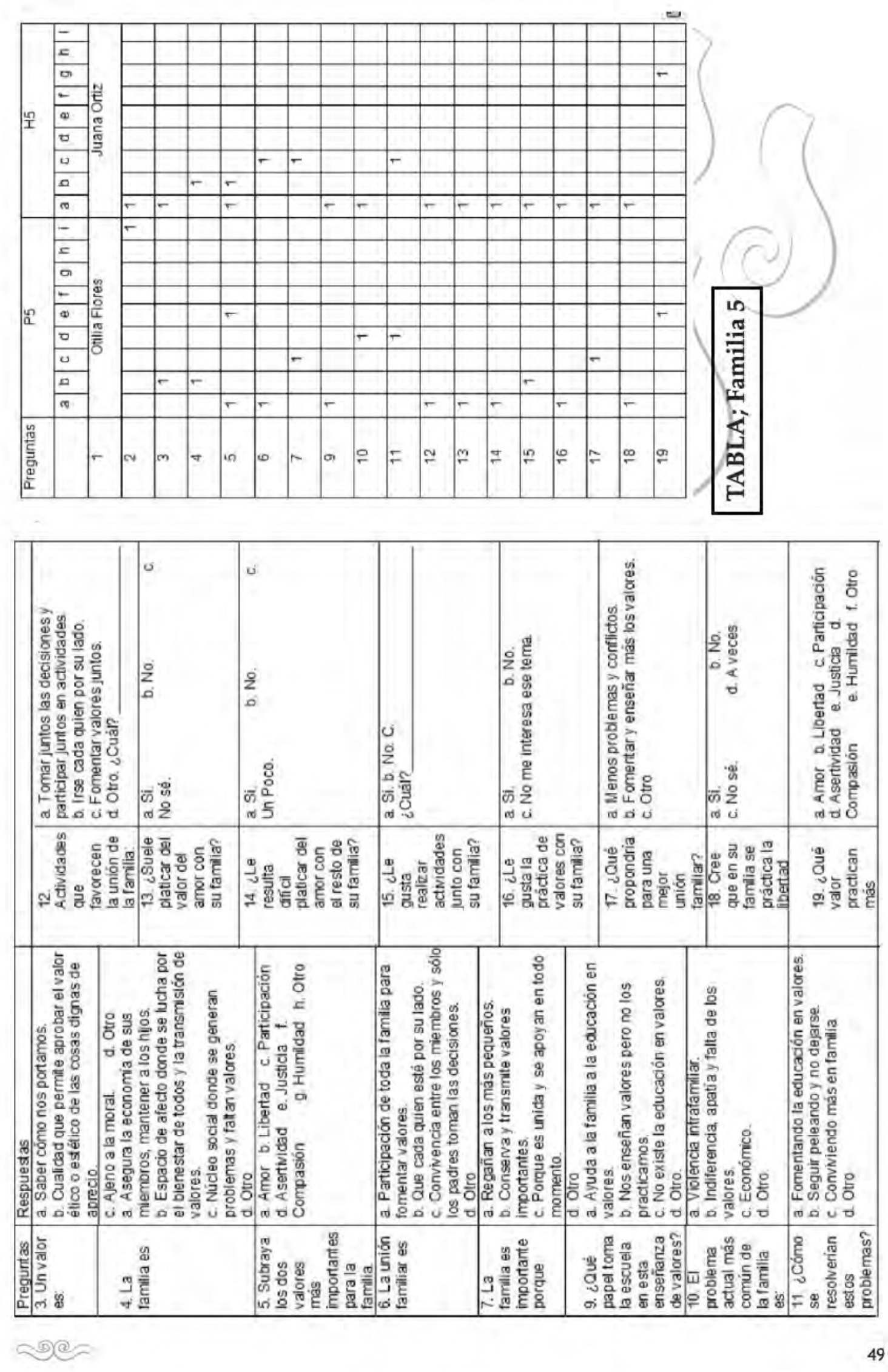


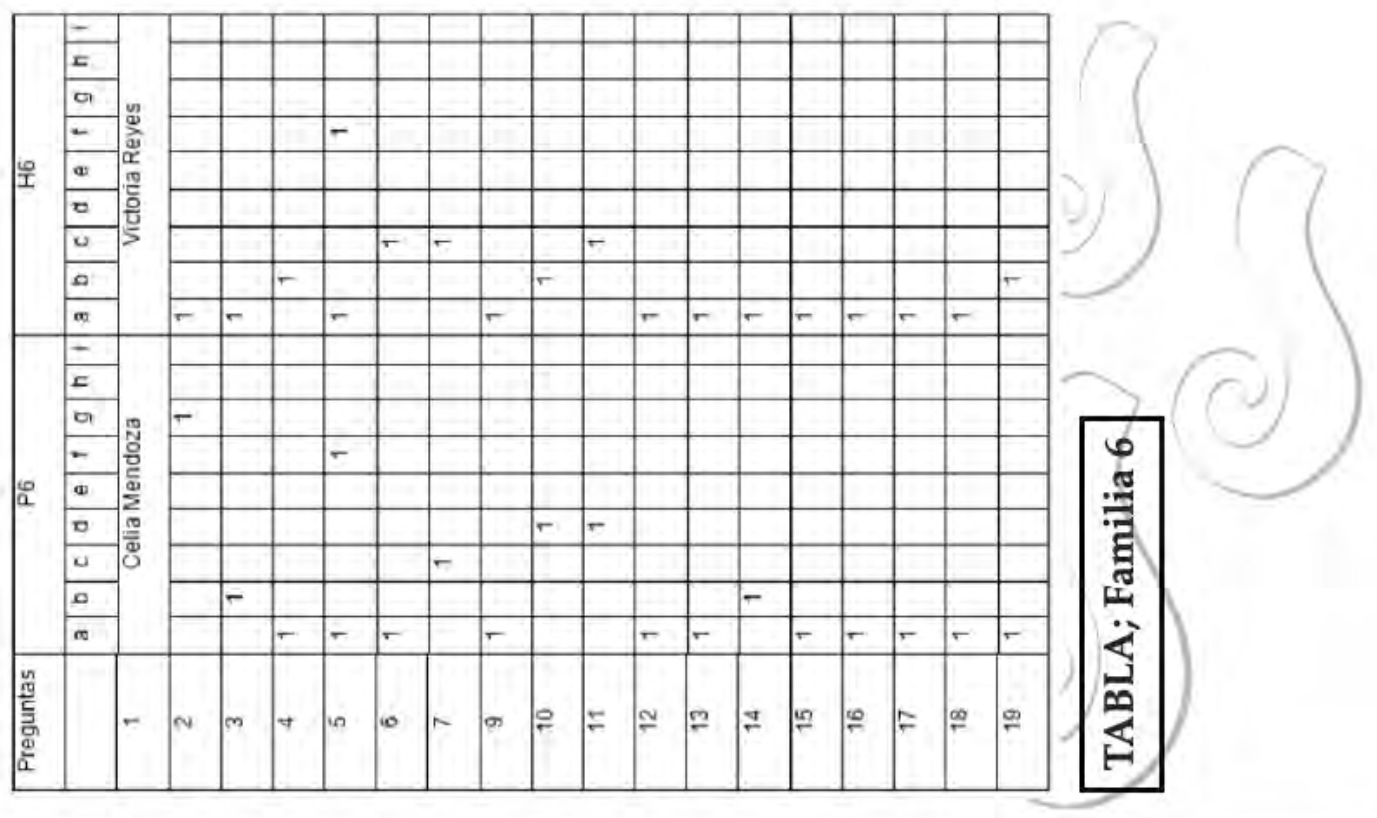

\begin{tabular}{|c|c|c|c|c|c|c|c|c|c|}
\hline \multicolumn{2}{|c|}{ 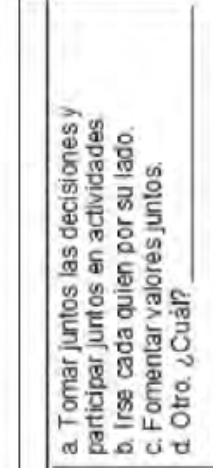 } & 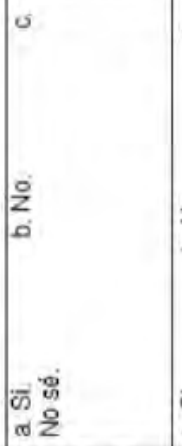 & 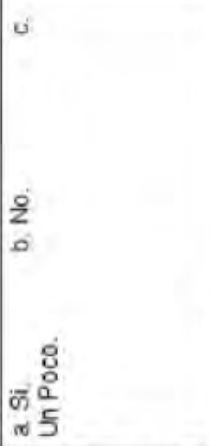 & 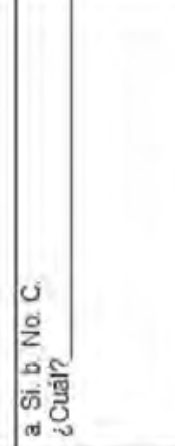 & \multicolumn{2}{|l|}{ | } & 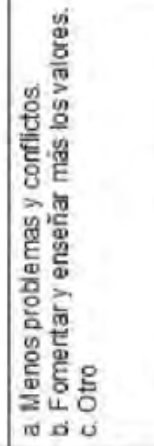 & 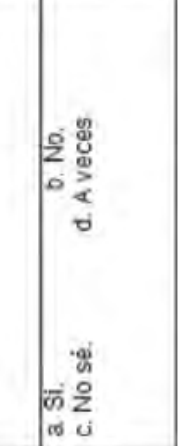 & 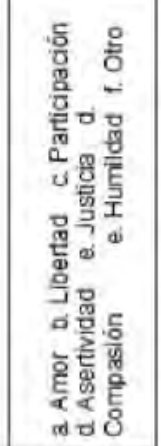 \\
\hline \multicolumn{2}{|c|}{ 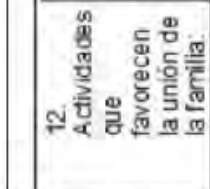 } & 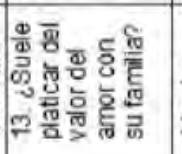 & 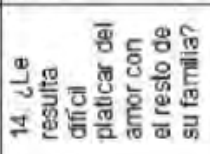 & 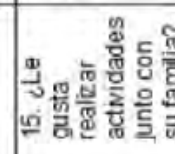 & \multicolumn{2}{|c|}{ 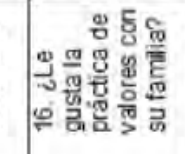 } & 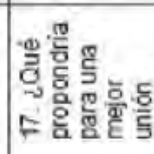 & 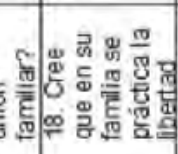 & 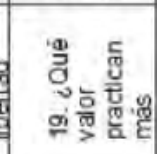 \\
\hline 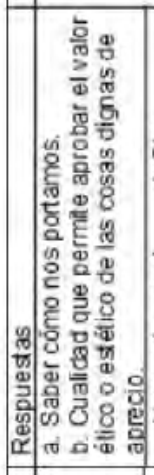 & & 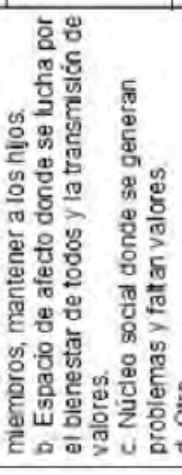 & 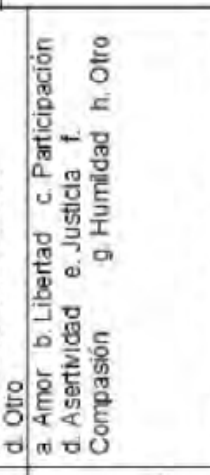 & 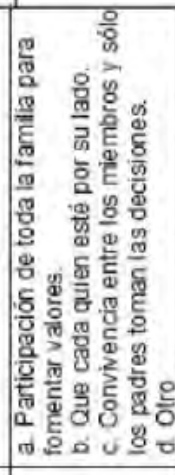 & 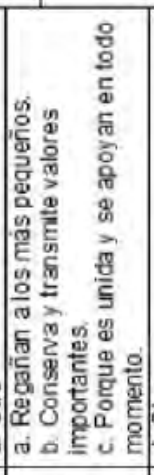 & & 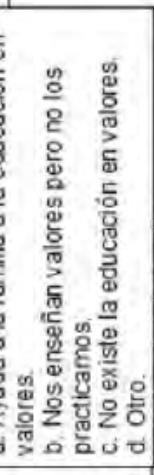 & 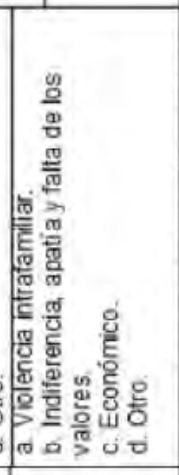 & 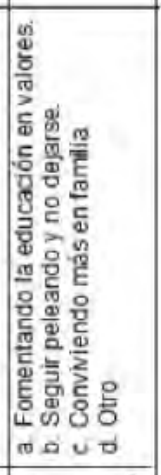 \\
\hline 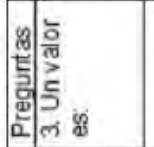 & षैS & I & 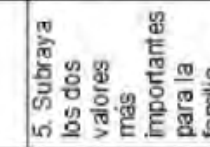 & 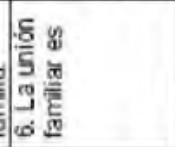 & 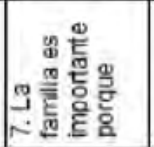 & & 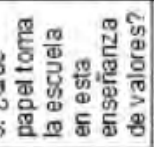 & 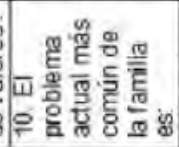 & 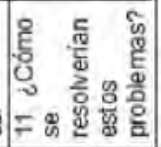 \\
\hline
\end{tabular}



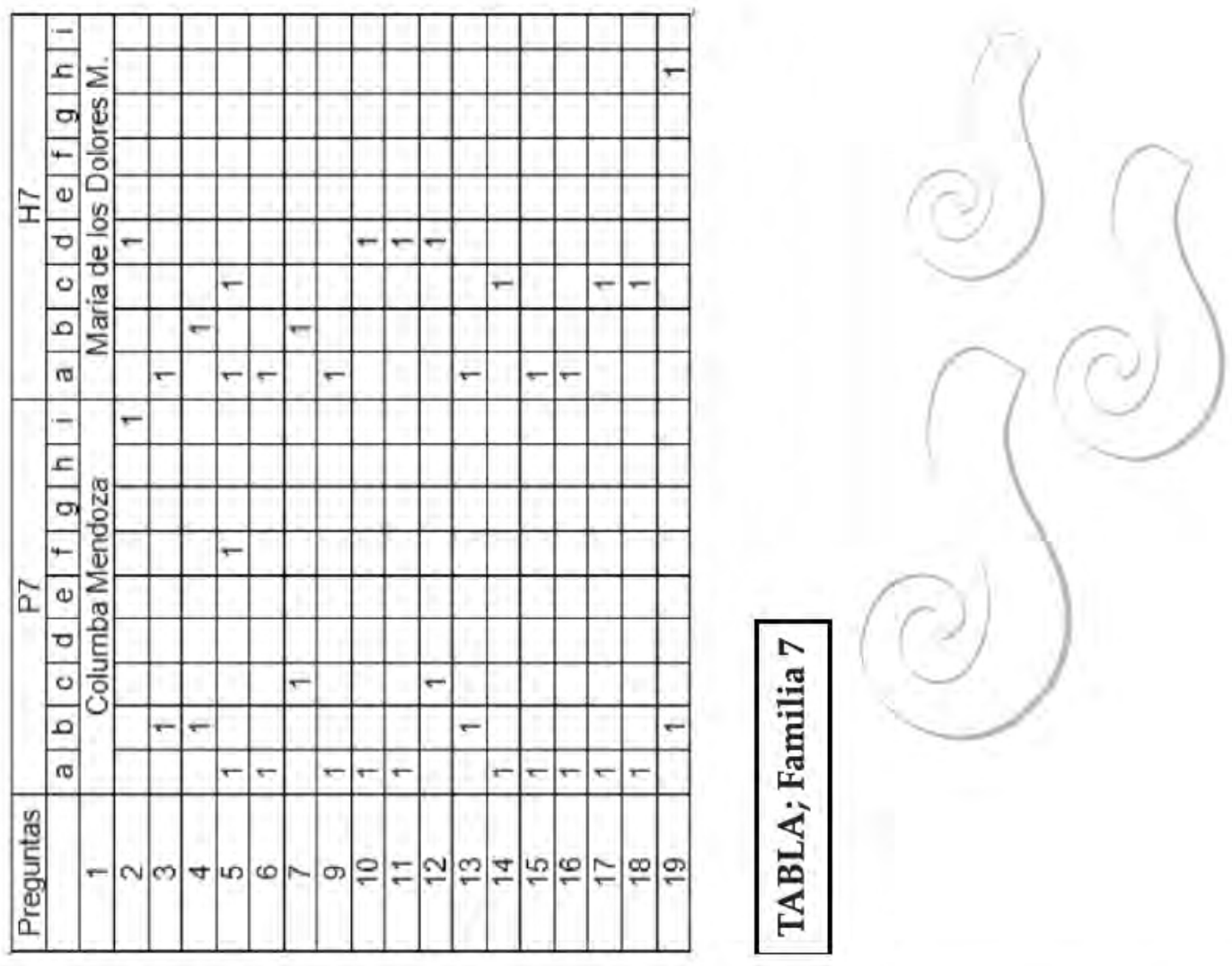

\begin{tabular}{|c|c|c|c|c|c|c|c|c|c|}
\hline \multicolumn{2}{|c|}{ 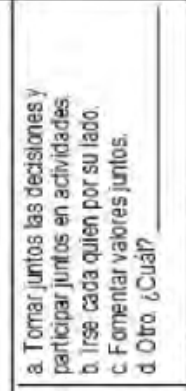 } & 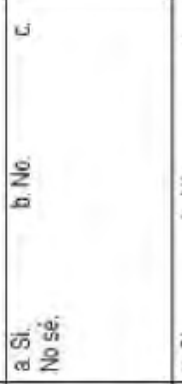 & 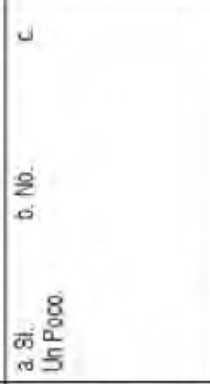 & 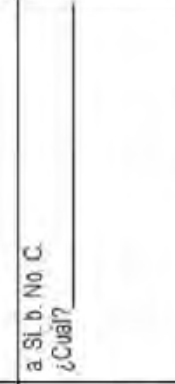 & \multicolumn{2}{|l|}{ 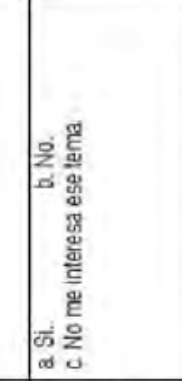 } & 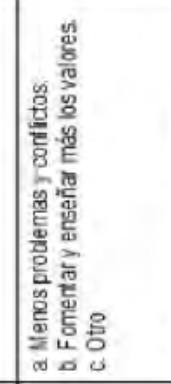 & 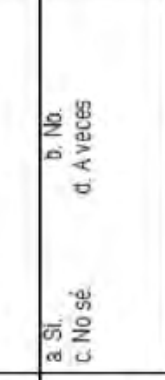 & 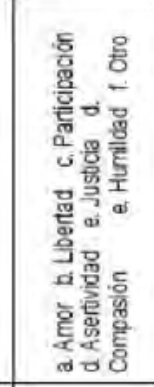 \\
\hline 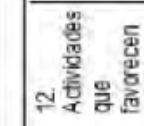 & & 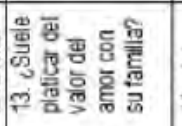 & & 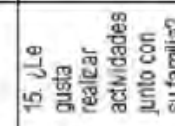 & 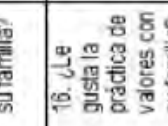 & & & 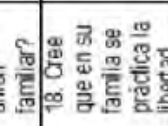 & \\
\hline 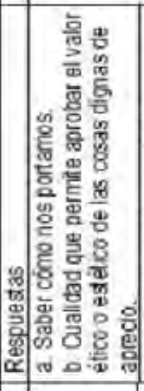 & & 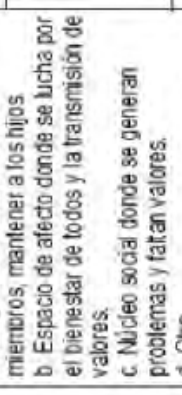 & 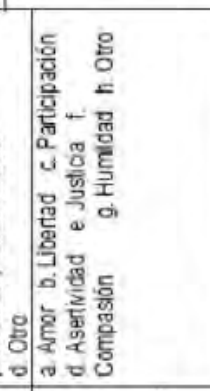 & 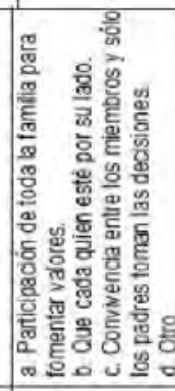 & 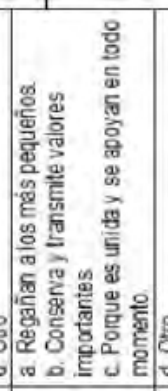 & & 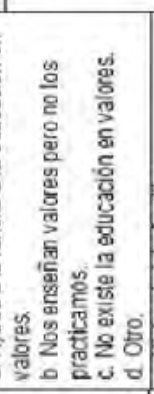 & 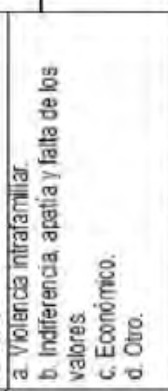 & 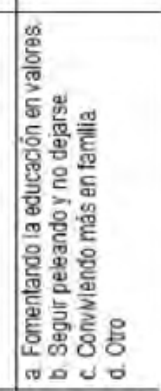 \\
\hline 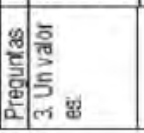 & & & 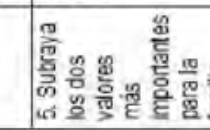 & 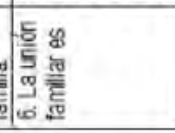 & 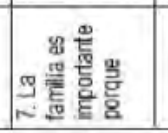 & & 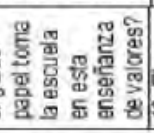 & 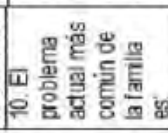 & 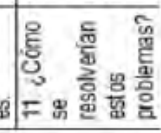 \\
\hline
\end{tabular}



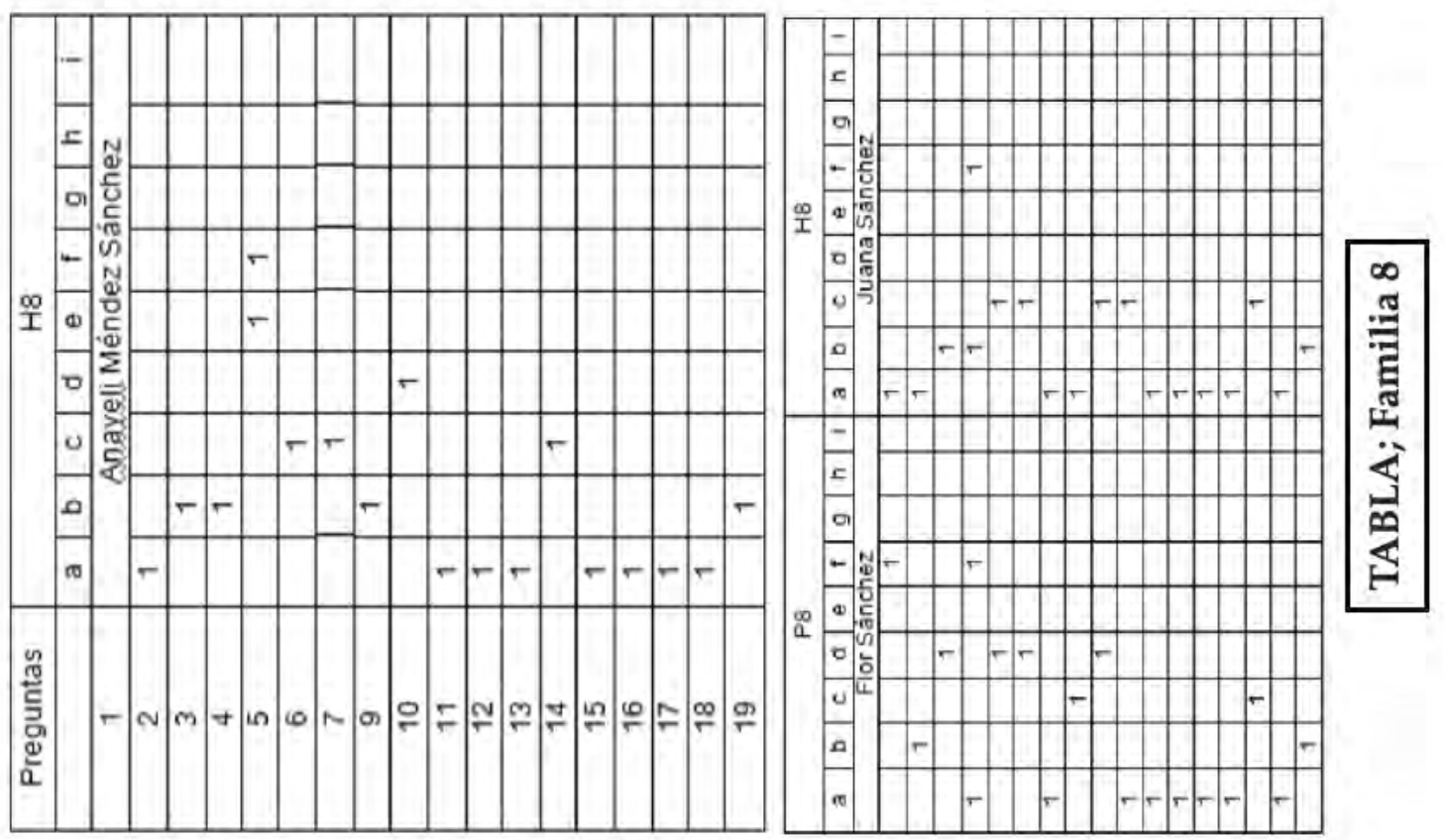

\begin{tabular}{|c|c|c|c|c|c|c|c|c|c|}
\hline 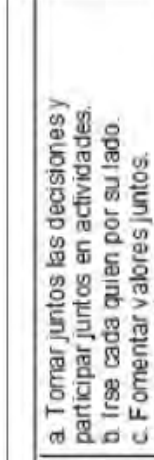 & & 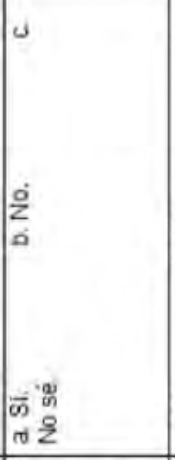 & 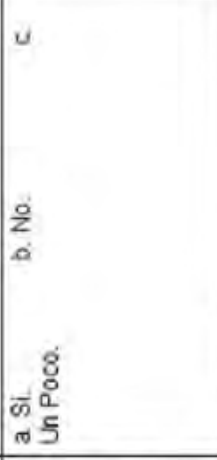 & 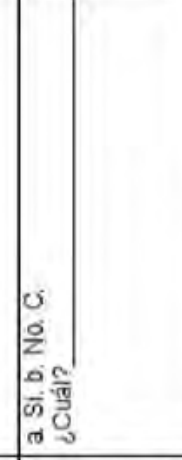 & 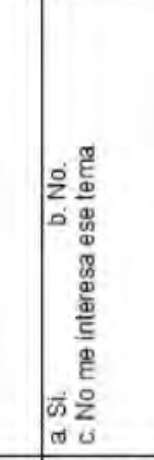 & & 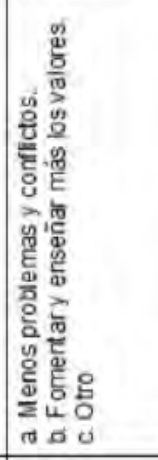 & 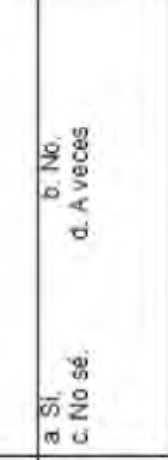 & 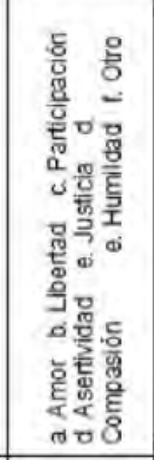 \\
\hline 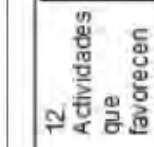 & & 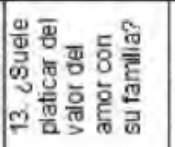 & 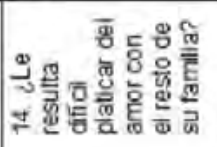 & 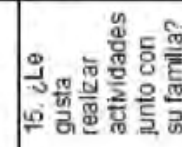 & 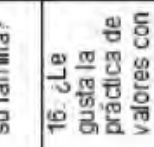 & & 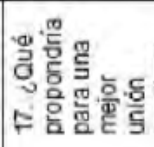 & 30 & 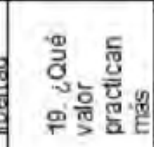 \\
\hline 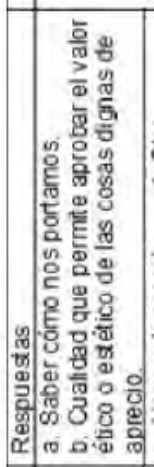 & 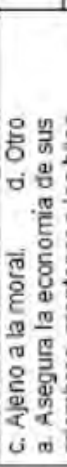 & 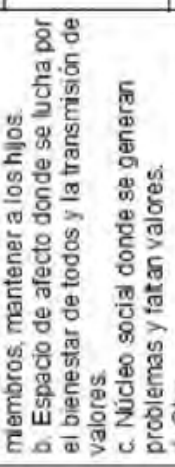 & 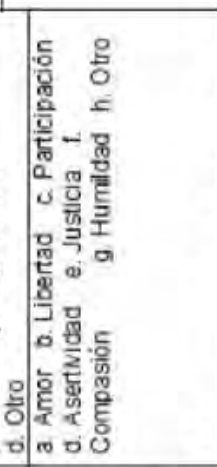 & 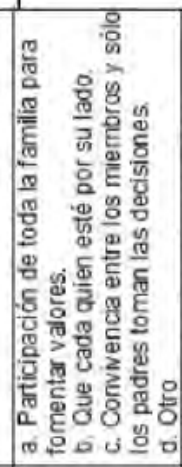 & 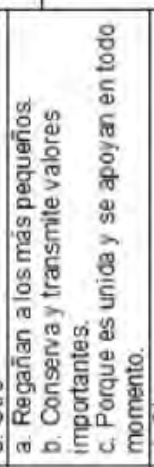 & & 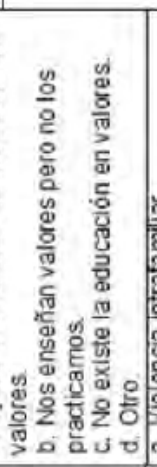 & 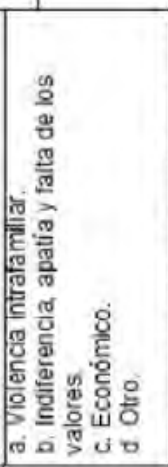 & 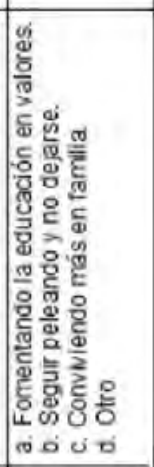 \\
\hline 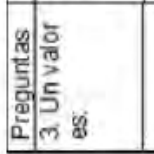 & $m=$ & & 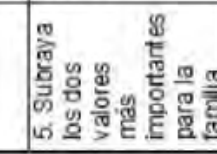 & 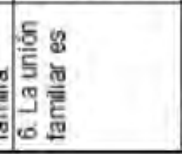 & 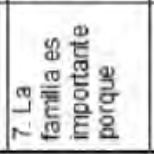 & & 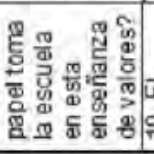 & 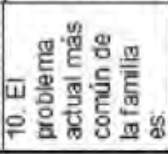 & 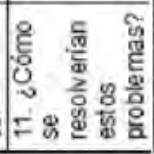 \\
\hline
\end{tabular}




\begin{tabular}{|c|c|c|c|c|c|c|c|c|c|c|c|c|c|c|c|c|c|c|}
\hline & -1 & - & & & & & & & & & & & & & & & & \\
\hline & $=0$ & 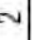 & & & & & & & & & & & & & & & & in \\
\hline & o & ता & & & & & & & & & & & & & & & & $=$ \\
\hline & -1 & an & & & $1-5$ & & & & & & & & & & & & & ov \\
\hline 娄 & 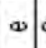 & $\sim$ & & & o) & & & & & & & & & & & & & $\sim$ \\
\hline & 0 & $\sim$ & $m$ & $\sim$ & $\sim$ & $d$ & $m$ & $\sim$ & 0 & क & $\sim$ & & & & & & $m$ & . \\
\hline & 0 . & $\sim$ & & - & $m$ & $=$ & $\approx$ & & os & 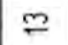 & in & & 으 & & & $\infty$ & $\sim$ & $\infty$ \\
\hline & a a. & & $-\infty$ & $\sim N$ & का & & $\nabla$ & $n$ & $n$ & & & $m$ & or & - & & -8 & & $\infty$ \\
\hline & 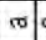 & $\infty$ & $\infty$ & in & $\sim \infty$ & rin & & $\sim m$ & $\infty$ & $\infty$ & $\sim m$ & Nr & - & $\sim \sigma$ & mo & -0 & $\sim$ in & $\infty$ \\
\hline & - & $\nabla$ & & & & & & & & & & & & & & & & 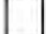 \\
\hline & $=1$. & -1 & & & $\sim$ & & & & & & & & & & & & & $\mathrm{m}$ \\
\hline & 며 & & & & $r$ & & & & & & & & & & & & & $\sim$ \\
\hline & - & & & & 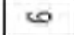 & & & & & & & & & & & & & $\infty$ \\
\hline 민 & $\Phi$ & & & & 10 & & & & & & & & & & & & & $\sim$ \\
\hline 통 & o. & - & & & & & - & - & $\sim$ & -5 & - & & & & & & & 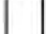 \\
\hline & 0 . & - & - & $\sim$ & $n$ & 우 & $\approx$ & & 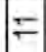 & $N$ & $\infty$ & & $\nabla$ & & & $N$ & & - \\
\hline & مـ & & or & 유 & an & - & o & ص & $\sim$ & & - & $\checkmark$ & or & - & - & $\omega$ & & in \\
\hline & s & $\simeq$ & a & $r$ & $\infty$ & $\infty$ & & $\simeq$ & $\nabla$ & $\leftarrow$ & क & $\stackrel{2}{\tau}$ & $\omega$ & $\infty$ & $\stackrel{\infty}{\tau}$ & $\omega$ & 프 & $\theta$ \\
\hline 总 & & $\sim$ & $m$ & $\nabla$ & $\infty$ & 0 & $N$ & a & 우 & $F$ & $\approx$ & 2 & 푸 & $\stackrel{2}{\circ}$ & 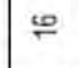 & $=$ & 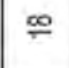 & $\%$ \\
\hline
\end{tabular}

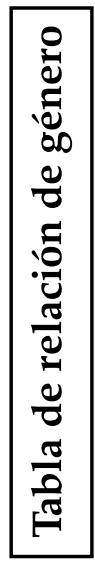

\begin{tabular}{|c|c|c|c|c|c|c|c|c|c|}
\hline 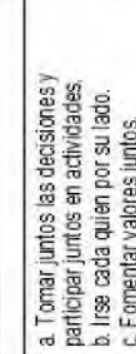 & & 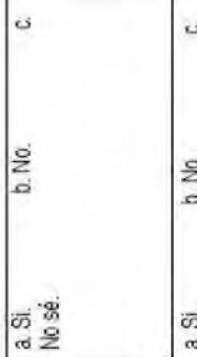 & 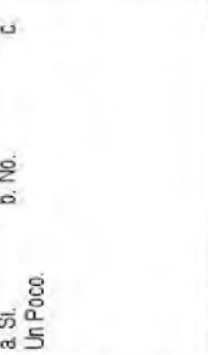 & 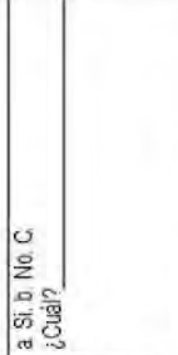 & 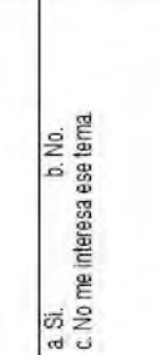 & & 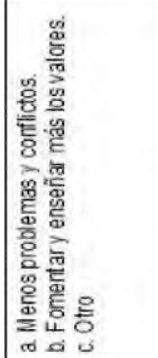 & 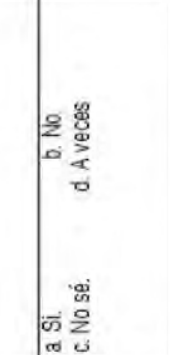 & 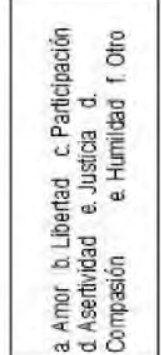 \\
\hline 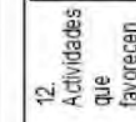 & 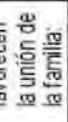 & 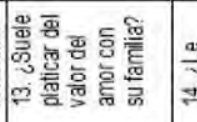 & 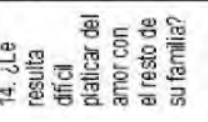 & 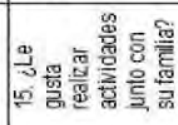 & 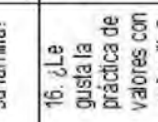 & & 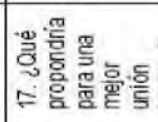 & 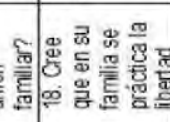 & 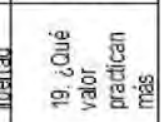 \\
\hline 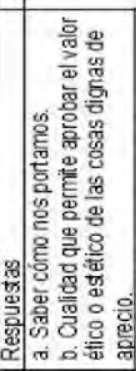 & 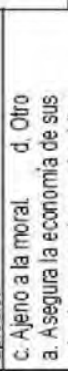 & 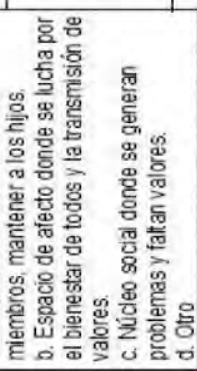 & 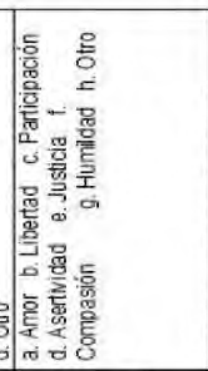 & 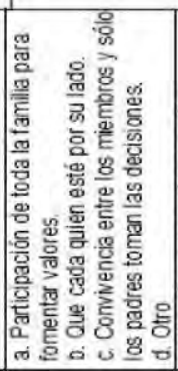 & 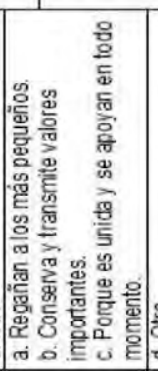 & 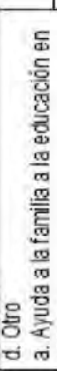 & 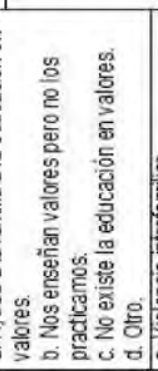 & 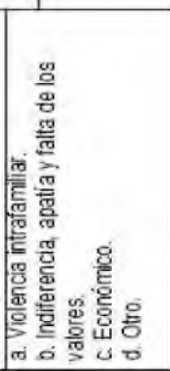 & 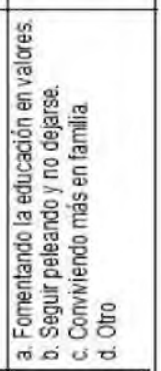 \\
\hline 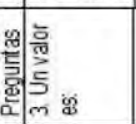 & ت & 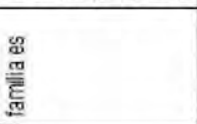 & 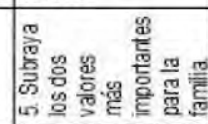 & 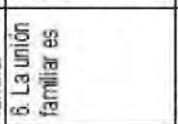 & 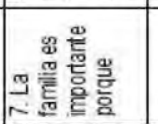 & & 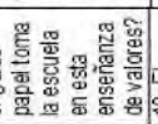 & 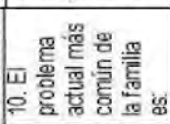 & 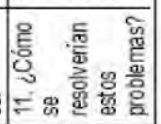 \\
\hline
\end{tabular}



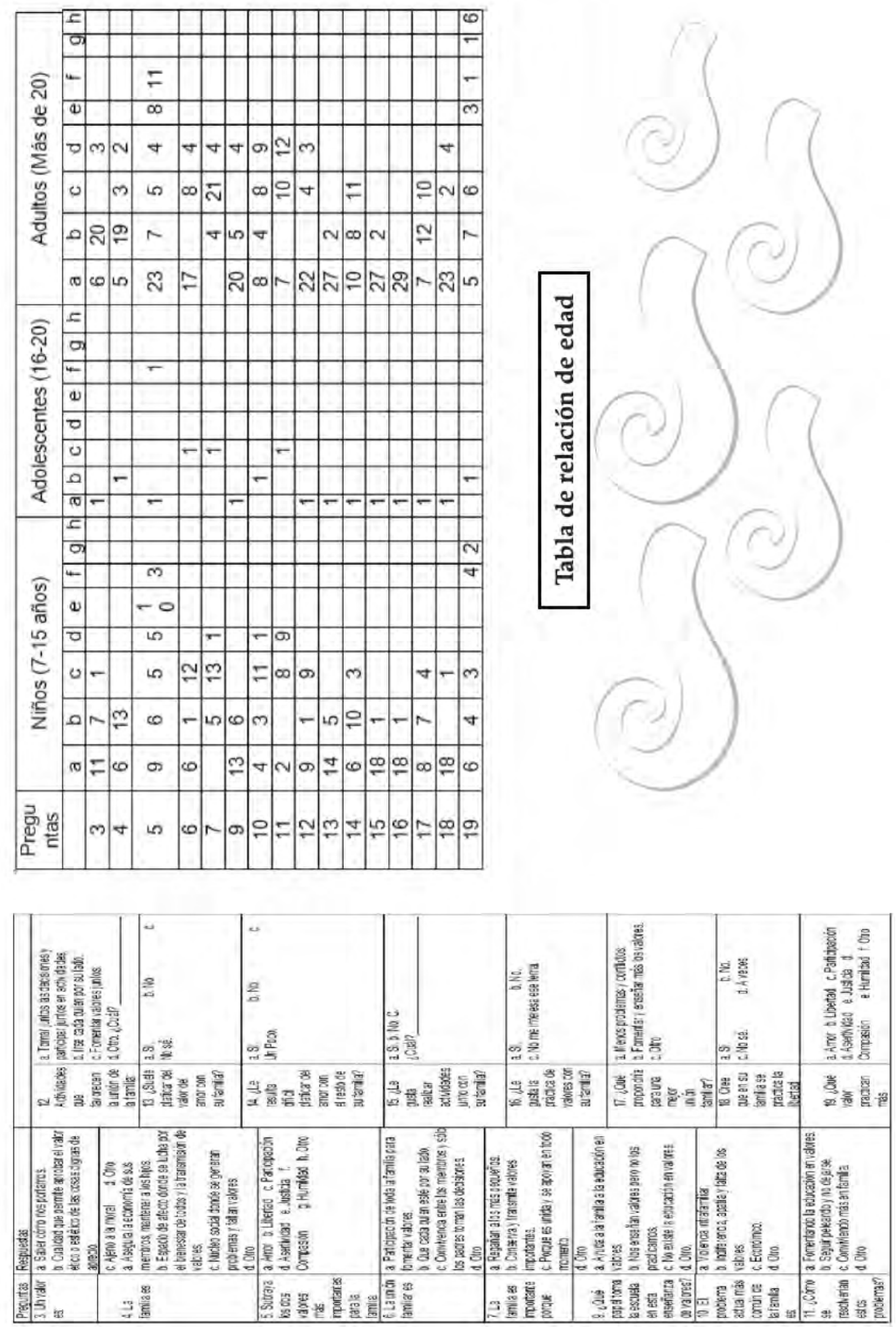
ANEXOS III

Gráficas de la investigación de Ayahualulco Veracruz

2. Edad:
a. Menos de 15.
b. Entre 15-20.
c. Entre 20-25.
d. Entre 25-30.
e. Entre 30-35.
f. Entre 35-40.
g. Entre 40-45.
h. Entre $45-50$.
i. Más de 50.

\begin{tabular}{|c|c|}
\hline Respuestas & No. Personas \\
\hline A & 20 \\
\hline B & 0 \\
\hline C & 3 \\
\hline D & 3 \\
\hline E & 2 \\
\hline F & 5 \\
\hline G & 2 \\
\hline H & 3 \\
\hline I & 11 \\
\hline TOTAL & 49 \\
\hline
\end{tabular}

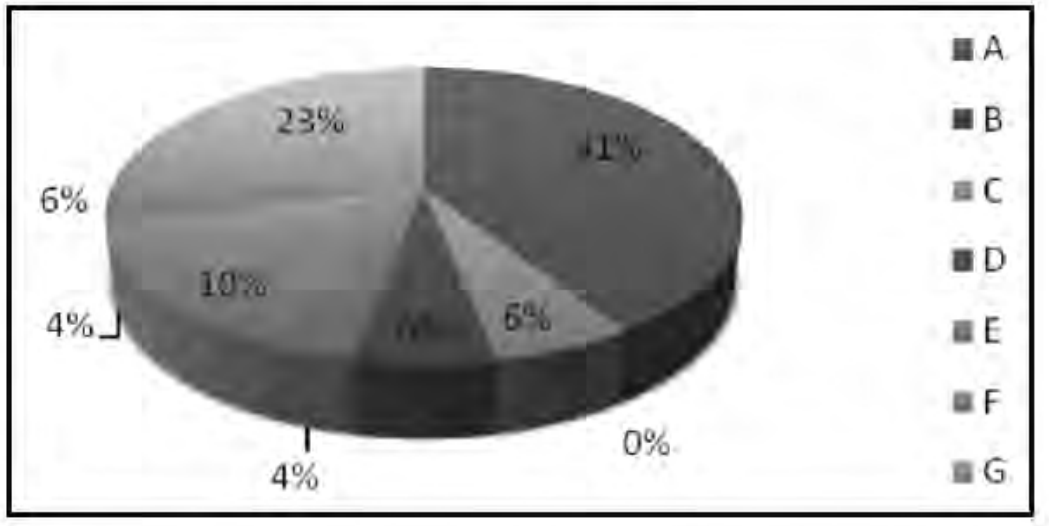

3. Un valor es:

a. Saber cómo nos portamos.

b. Cualidad que permite aprobar el valor ético o estético de las cosas dignas de aprecio.

c. Ajeno a la moral.

d. Otro ¿Cuál?

\begin{tabular}{|c|c|}
\hline Respuestas & No. personas \\
\hline A & 17 \\
\hline B & 28 \\
\hline C & 1 \\
\hline D & 3 \\
\hline TOTAL & 49 \\
\hline
\end{tabular}

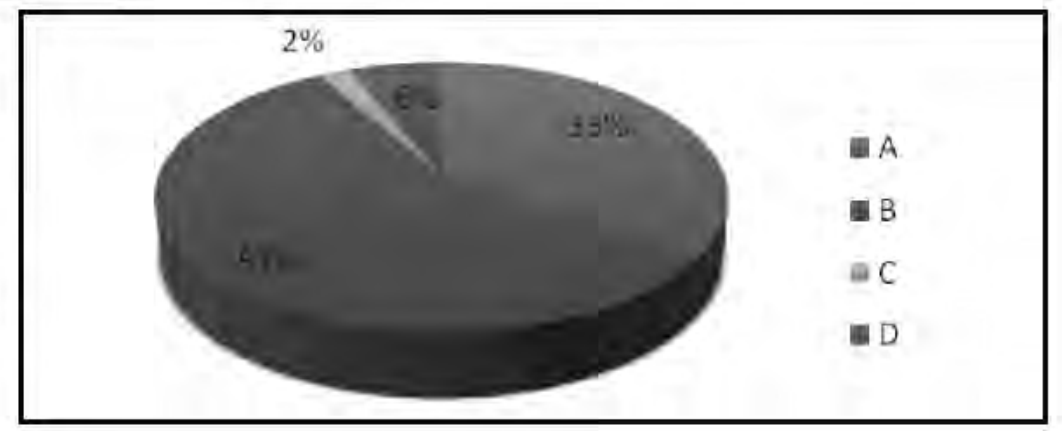

4. La familia es:

a. Asegura la economía de sus miembros, mantener a los hijos.

b. Espacio de afecto donde se lucha por el bienestar de todos y la transmisión de valores.

c. Núcleo social donde se generan problemas y faltan valores.

d. Otro ¿Cuál?

\begin{tabular}{|c|c|}
\hline Respuestas & No. Personas \\
\hline A & 12 \\
\hline B & 32 \\
\hline C & 3 \\
\hline D & 2 \\
\hline TOTAL & 49 \\
\hline
\end{tabular}

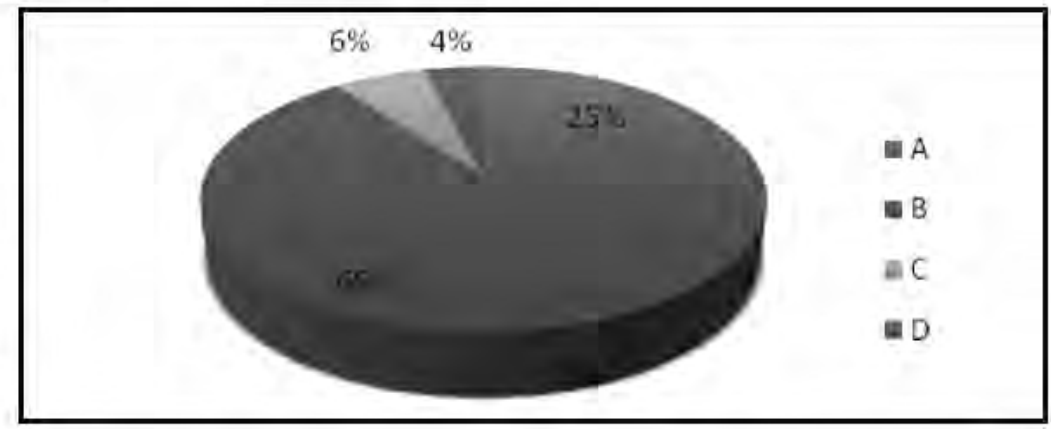


5. Subraya los dos valores más importantes para la familia.
a. Amor
b. Libertad
c. Participación
d. Asertividad
e. Justicia
f. Compasión
g. Humildad
h. Otro ¿Cuál?

\begin{tabular}{|c|c|}
\hline Respuestas & $\begin{array}{c}\text { No. } \\
\text { personas }\end{array}$ \\
\hline A & 34 \\
\hline B & 14 \\
\hline C & 8 \\
\hline D & 2 \\
\hline E & 14 \\
\hline F & 17 \\
\hline G & 7 \\
\hline H & 2 \\
\hline TOTAL & 98 \\
\hline
\end{tabular}

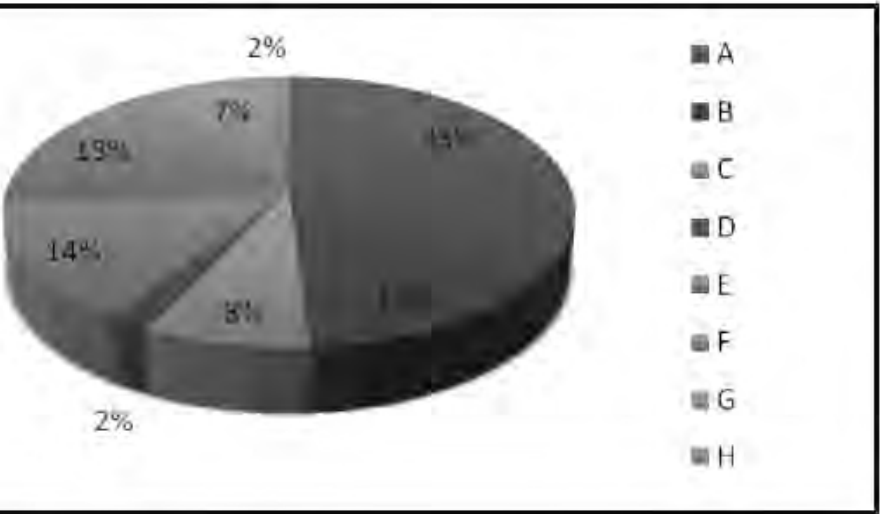

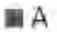

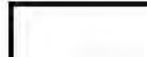

6. La unión familiar es:

a. Participación de toda la familia para fomentar valores.

b. Que cada quien esté por su lado.

c. Convivencia entre los miembros y sólo los padres toman las decisiones.

d. Otro ¿Cuál?

\begin{tabular}{|c|c|}
\hline Respuestas & No. personas \\
\hline A & 23 \\
\hline B & 1 \\
\hline C & 21 \\
\hline D & 4 \\
\hline TOTAL & 49 \\
\hline
\end{tabular}

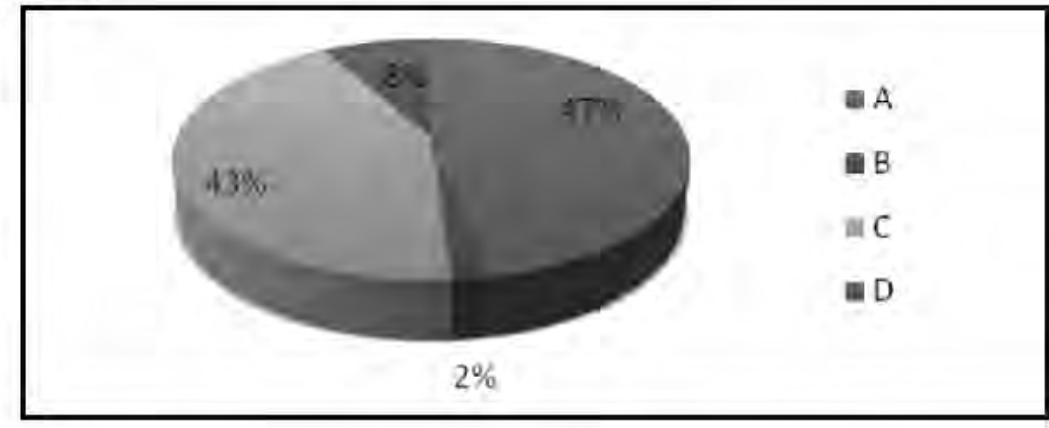

7. La familia es importante porque:

a. Regañan a los más pequeños.

b. Conserva y transmite valores importantes.

c. Porque es unida y se apoyan en todo momento.

d. Otro. ¿Cuál?

\begin{tabular}{|c|c|}
\hline Respuestas & No. personas \\
\hline A & 0 \\
\hline$B$ & 10 \\
\hline C & 35 \\
\hline D & 4 \\
\hline TOTAL & 49 \\
\hline
\end{tabular}

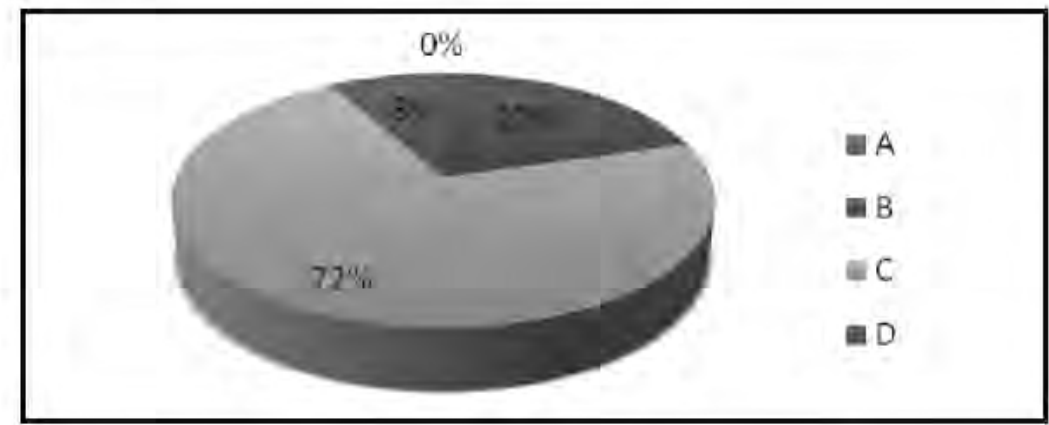


9.¿Qué papel toma la escuela en esta enseñanza de valores?
a. Ayuda a la familia a la educación en valores.
b. Nos enseñan valores pero no los practicamos.
c. No existe la educación en valores.
d. Otro ¿Cuál?

\begin{tabular}{|c|c|}
\hline Respuestas & No. personas \\
\hline A & 35 \\
\hline$B$ & 11 \\
\hline C & 0 \\
\hline D & 3 \\
\hline TOTAL & 49 \\
\hline
\end{tabular}

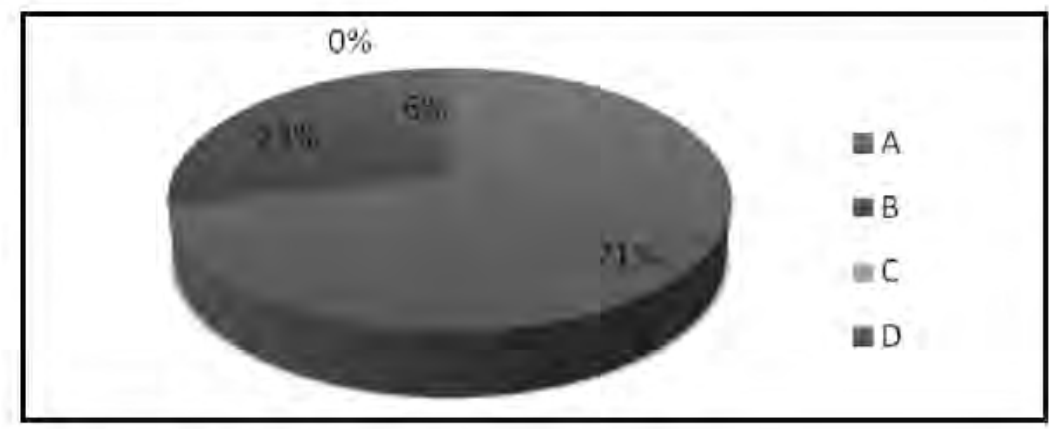

10. El problema actual más común de la familia es:

a. Violencia intrafamiliar.

b. Indiferencia, apatía y falta de los valores.

c. Económico.

d. Otro. ¿Cuál?

\begin{tabular}{|c|c|}
\hline Respuestas & No. personas \\
\hline A & 12 \\
\hline B & 9 \\
\hline C & 20 \\
\hline D & 8 \\
\hline TOTAL & 49 \\
\hline
\end{tabular}

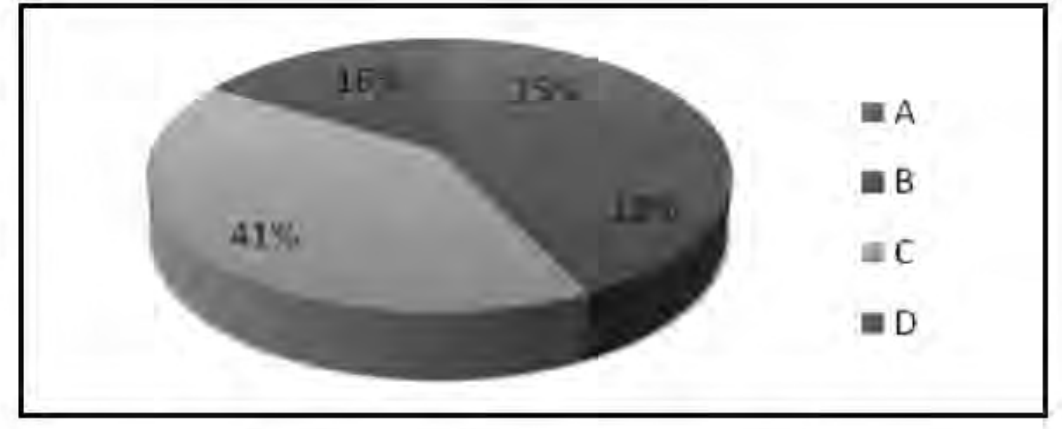

11. ¿Cómo se resolverían estos problemas?

a. Fomentando la educación en valores.

b. Seguir peleando y no dejarse.

c. Conviviendo más en familia.

d. Otro, ¿Cuál?

\begin{tabular}{|c|c|}
\hline Respuestas & No. personas \\
\hline$A$ & 9 \\
\hline$B$ & 0 \\
\hline$C$ & 20 \\
\hline$D$ & 20 \\
\hline TOTAL & 49 \\
\hline
\end{tabular}

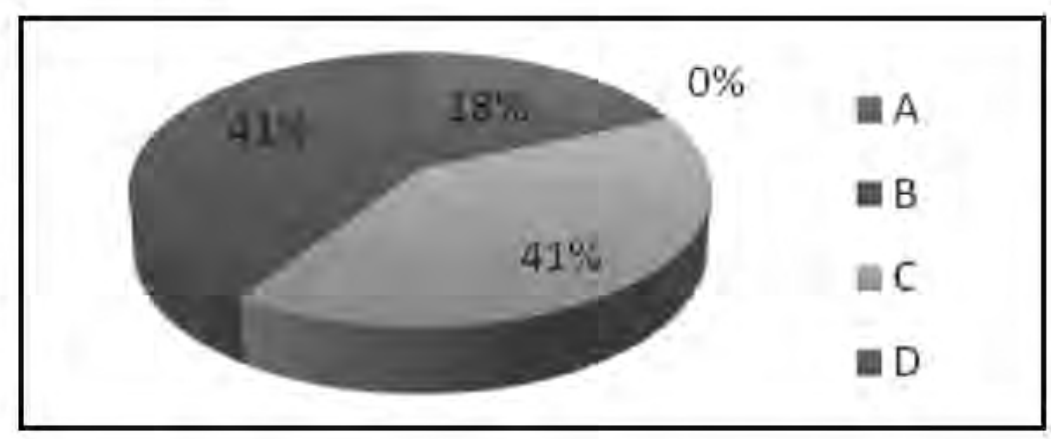


12. Actividades que favorecen la unión de la familia:

a. Tomar juntos las decisiones y participar juntos en actividades.

b. Irse cada quien por su lado.

c. Fomentar valores juntos.

d. Otro. ¿Cuál?

\begin{tabular}{|c|c|}
\hline Respuestas & No. personas \\
\hline A & 32 \\
\hline B & 1 \\
\hline C & 13 \\
\hline D & 3 \\
\hline TOTAL & 49 \\
\hline
\end{tabular}

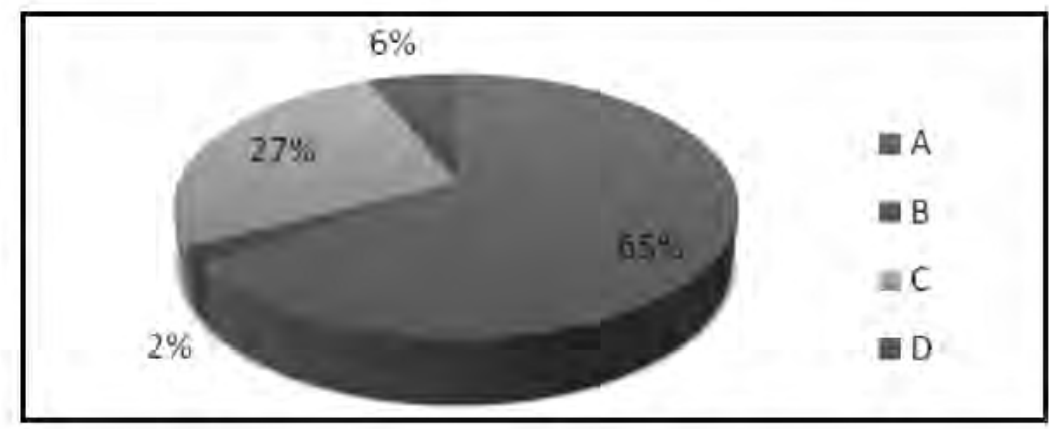

13. ¿Suele platicar del valor del amor con su familia?

a. Sí.

b. No.

c. No sé.

\begin{tabular}{|c|c|}
\hline Respuestas & No. personas \\
\hline A & 42 \\
\hline$B$ & 7 \\
\hline C & 0 \\
\hline TOTAL & 49 \\
\hline
\end{tabular}

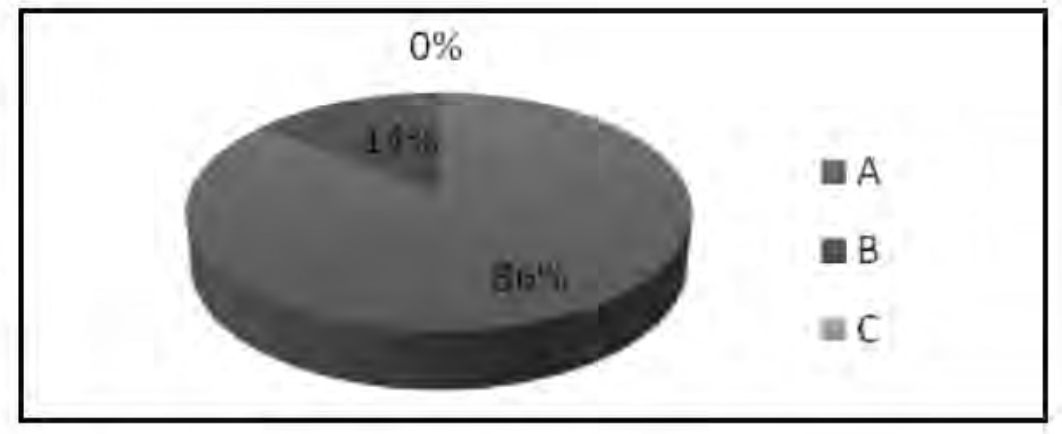

14. ¿Le resulta difícil platicar del amor con el resto de su familia?

a. Sí.

b. No.

c. Un Poco.

\begin{tabular}{|c|c|}
\hline Respuestas & No. personas \\
\hline A & 17 \\
\hline B & 18 \\
\hline C & 14 \\
\hline TOTAL & 49 \\
\hline
\end{tabular}

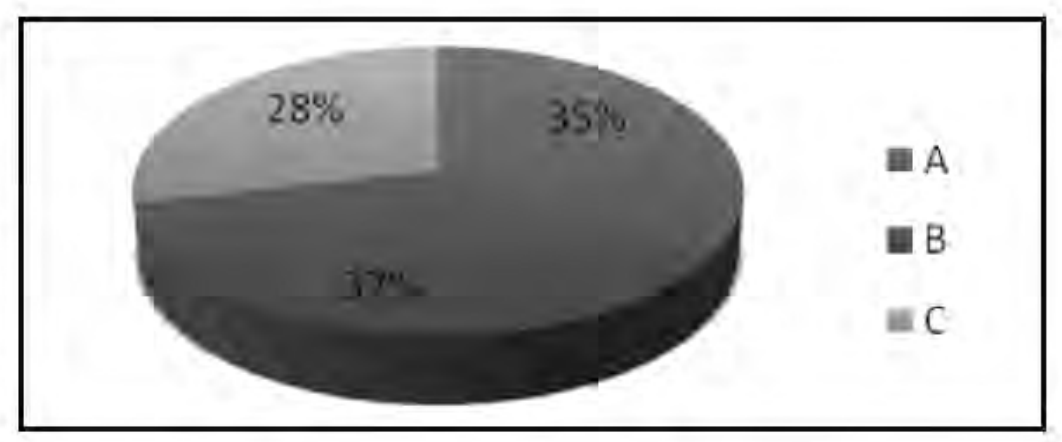


15. ¿Le gusta realizar actividades junto con su familia?

a. Sí. ¿Cuál?

b. No.

\begin{tabular}{|c|c|}
\hline Respuestas & No. personas \\
\hline$A$ & 47 \\
\hline$B$ & 2 \\
\hline TOTAL & 49 \\
\hline
\end{tabular}

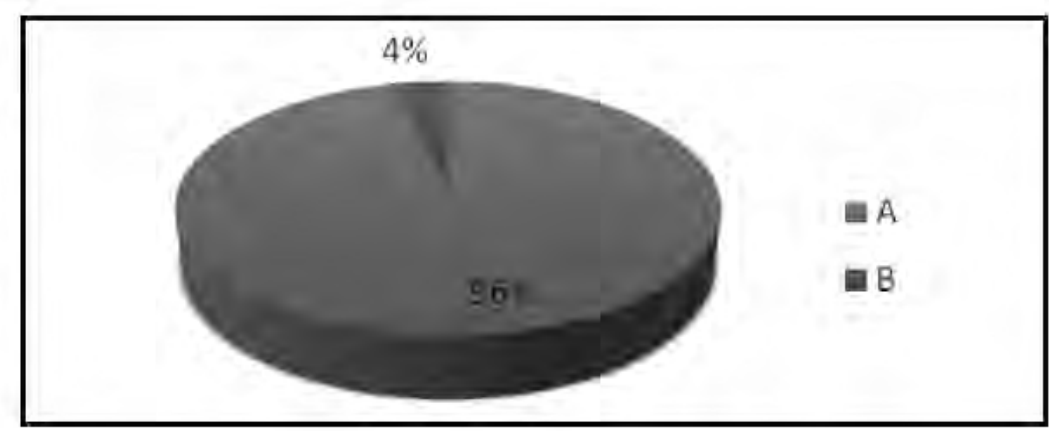

16. ¿Le gusta la práctica de valores con su familia?

a. Sí

b. No.

c. No me interesa ese tema.

\begin{tabular}{|c|c|}
\hline Respuestas & No. personas \\
\hline A & 48 \\
\hline$B$ & 1 \\
\hline C & 0 \\
\hline TOTAL & 49 \\
\hline
\end{tabular}

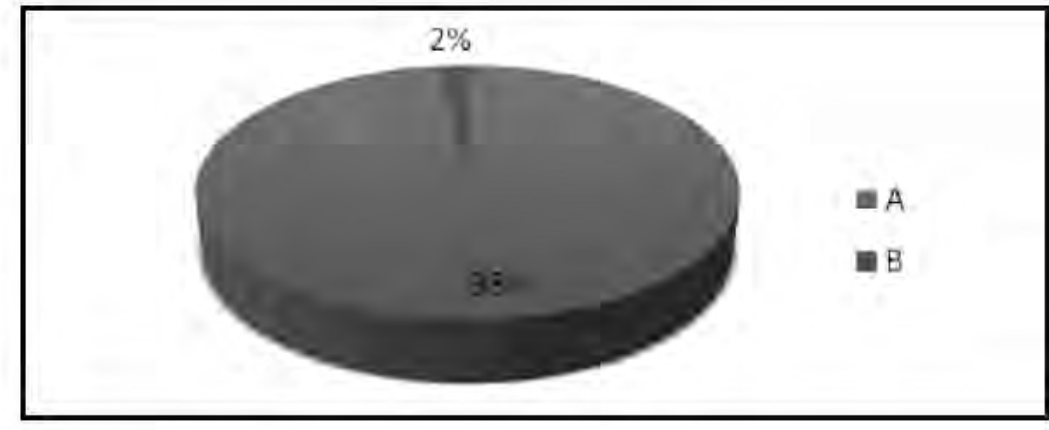

17. ¿Qué propondría para una mejor unión familiar?

a. Menos problemas y conflictos.

b. Fomentar y enseñar más los valores.

c. Otro. ¿Cuál?

\begin{tabular}{|c|c|}
\hline Respuestas & No. personas \\
\hline A & 16 \\
\hline B & 20 \\
\hline C & 13 \\
\hline TOTAL & 49 \\
\hline
\end{tabular}

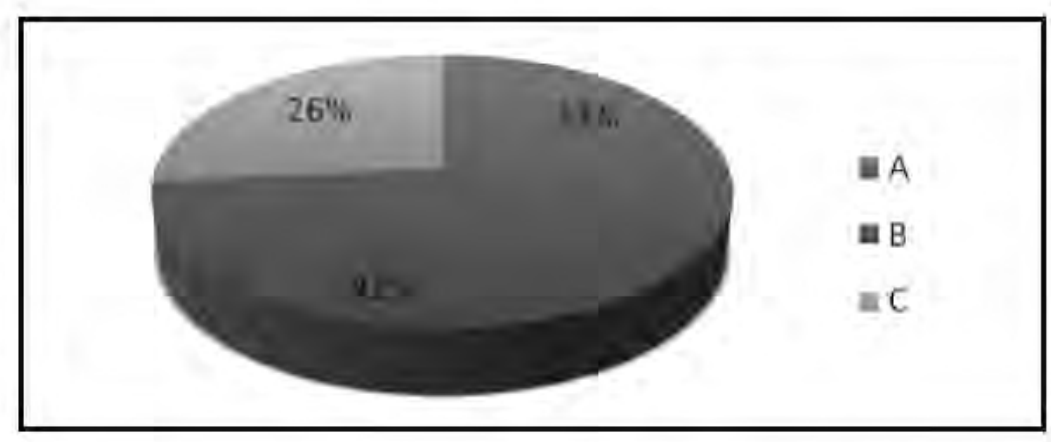


18. Cree que en su familia se práctica la libertad
a. Sí.
b. No.
c. No sé.
d. Aveces

\begin{tabular}{|c|c|}
\hline Respuestas & No. personas \\
\hline A & 44 \\
\hline B & 0 \\
\hline C & 2 \\
\hline D & 3 \\
\hline TOTAL & 49 \\
\hline
\end{tabular}

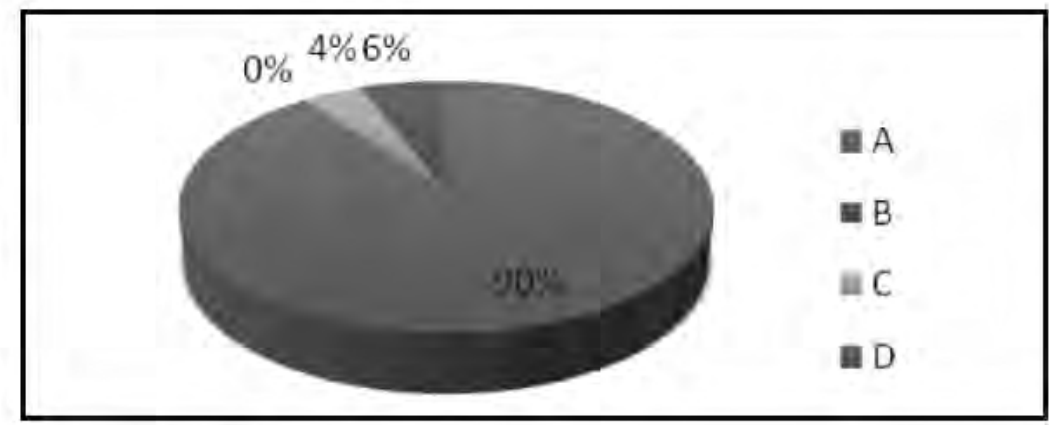

19. ¿Qué valor practican más en su familia?
a. Amor
b. Libertad
c. Participación
d. Asertividad
e. Justicia
d. Compasión
e. Humildad
f. Otro ¿Cuál?

\begin{tabular}{|c|c|}
\hline Respuestas & No. Personas \\
\hline A & 10 \\
\hline B & 11 \\
\hline C & 9 \\
\hline D & 0 \\
\hline E & 4 \\
\hline F & 4 \\
\hline G & 3 \\
\hline H & 8 \\
\hline TOTAL & 49 \\
\hline
\end{tabular}
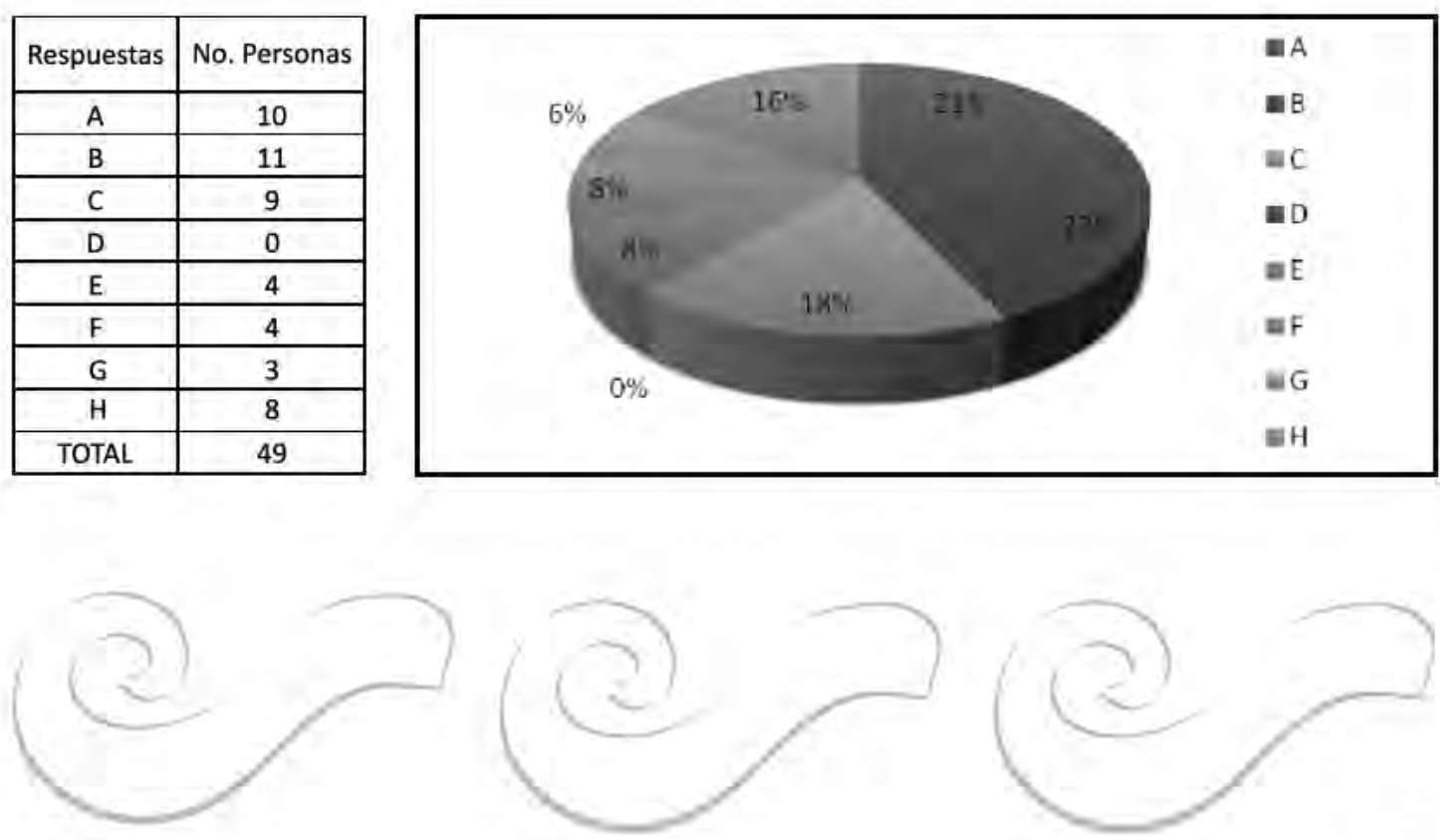

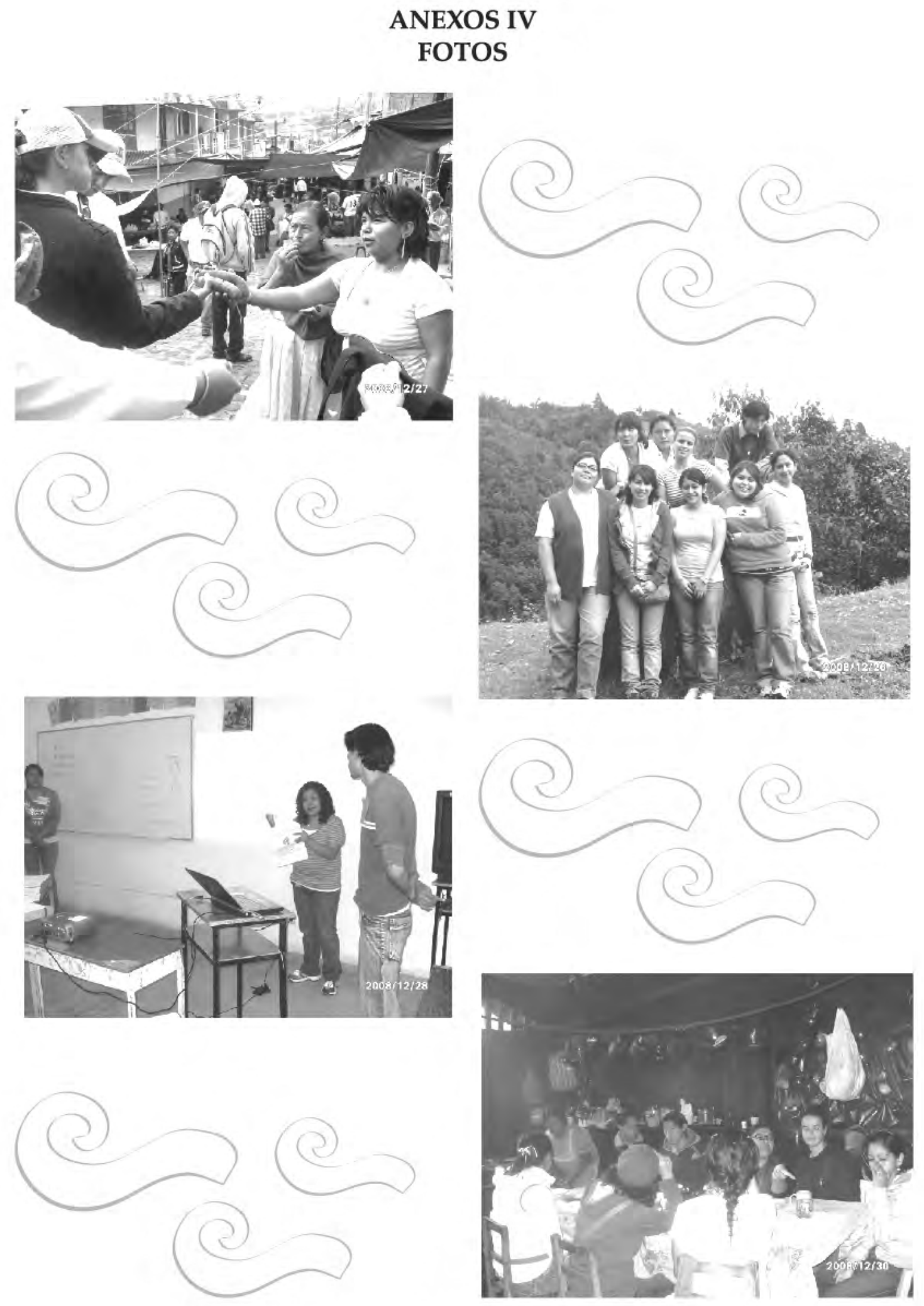

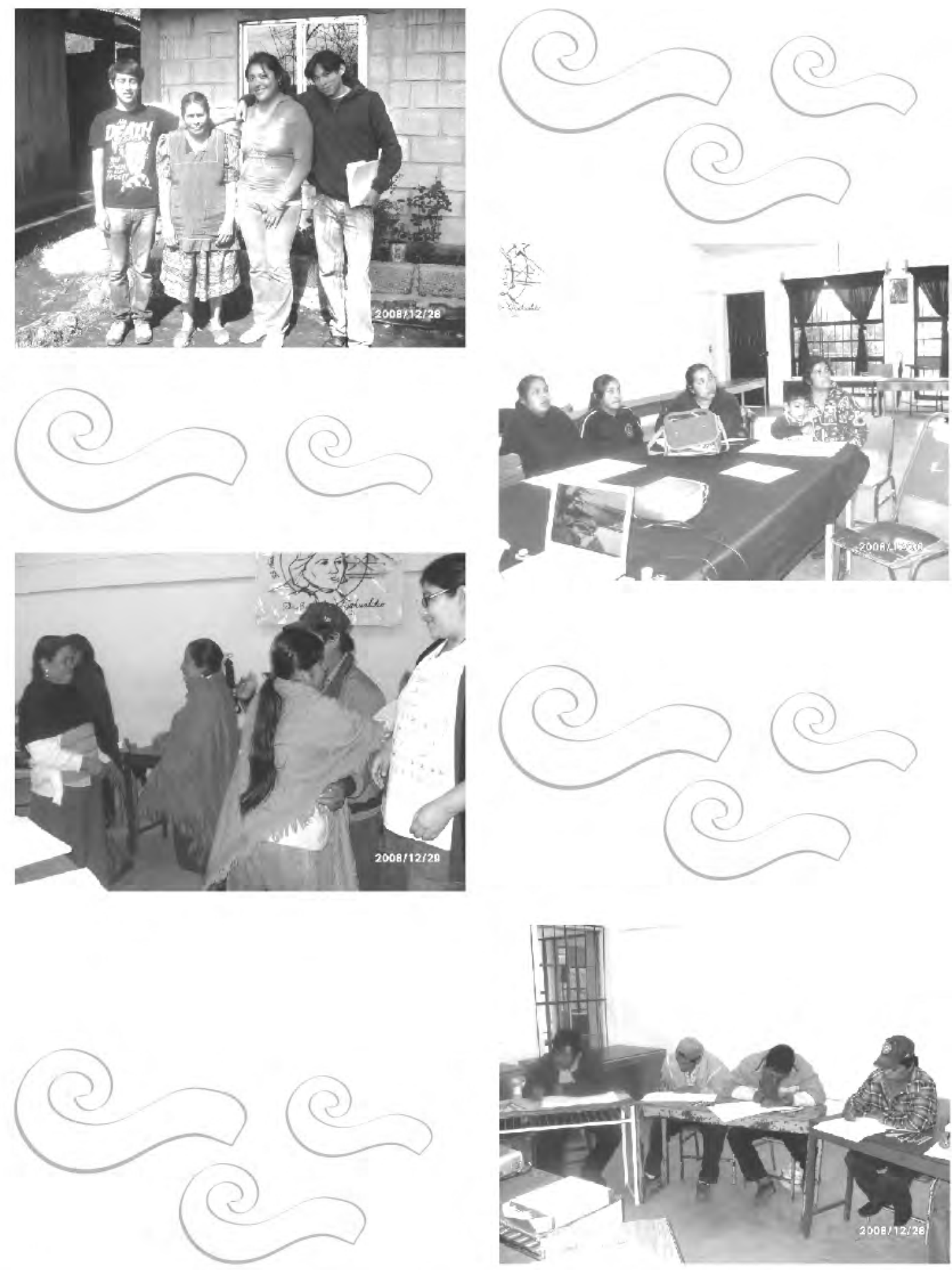

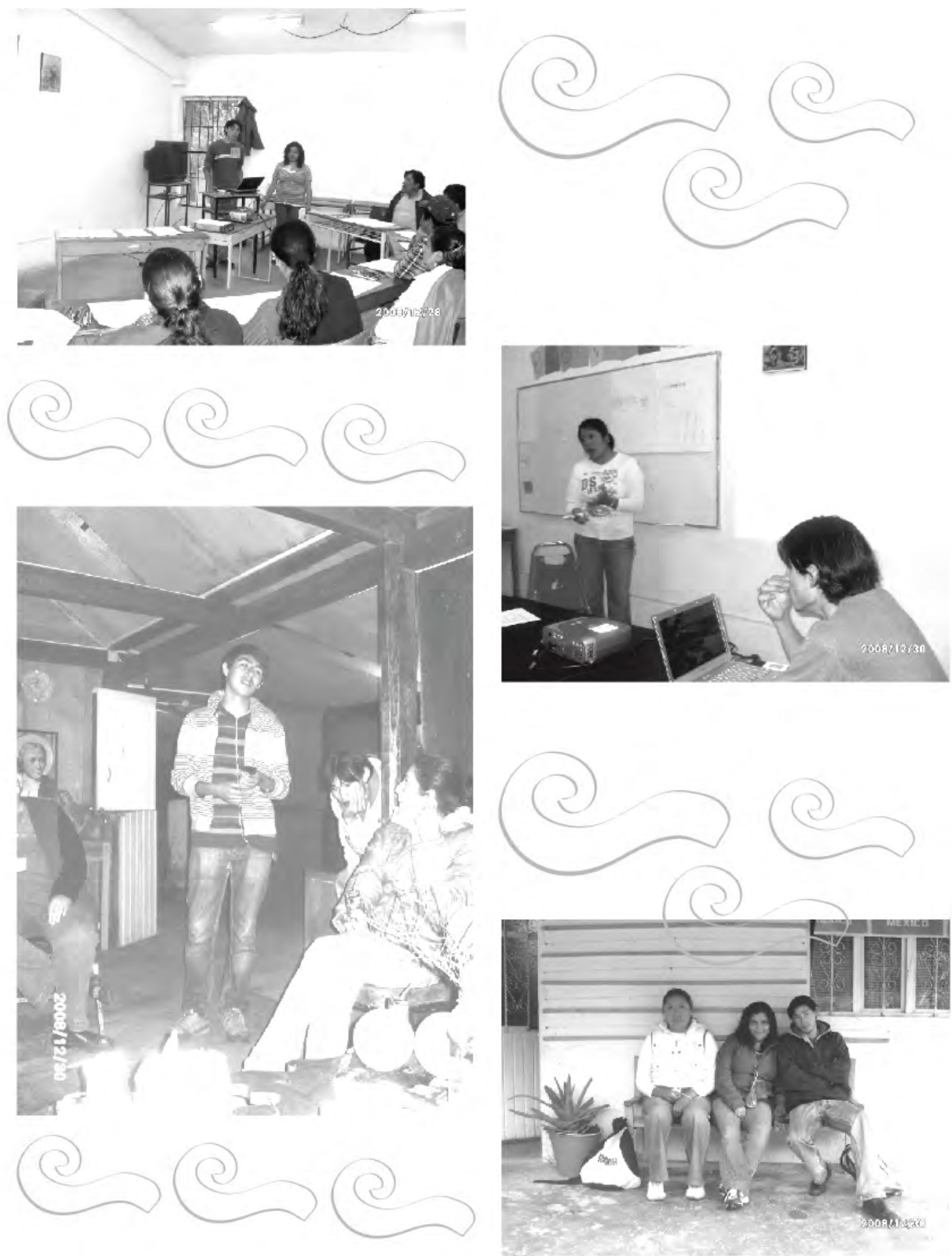


\section{Fuentes de consulta}

Comisión Nacional de los Derechos Humanos (2003). Programa para el fortalecimiento de la familia. México, D.F.

Fimpes. Comisión de valores. (2000). Primer Concurso Nacional: Los valores y la juventud de hoy. México, D.F.

Litzahaya Romero Campos en el ensayo Los valores y la juventud de hoy (2000)

María del P.G.L-P de Cordero. Coordinadora de la comisión de Valores.

Según Mariana Perillita Nava, en el ensayo Los valores y la juventud de hoy (2000)

Moguillansky, R. (1996). La Vida Emocional de la Familia. Buenos Aires: Ed. Lugar

Oliveros. F. Otero. (1999). Relaciones Humanas en la Familia. Madrid, España: Ed. Minos.

Tallabs Ortega, R. (2000). Crece valores para la vida $4^{\circ}$ primaria. México: Ed. Fomento Educativo.

Colaboradores de wikipedia. (2009). Familia. Recuperado el 28 de Febrero de 2009, en http://es.wikipedia.org/w/index.php?title $=$ Familia\&oldid $=24457831$.

Colaboradores de Wikipedia (2009). Amor. Recuperado el 28 de Mayo de 2009. en,http://es.wikipedia.org/w/index.php?title $=$ Especial:Citar\&page $=$ Amor\&id $=26814866$

Colaboradores de Wikipedia (2009). Libertad. Recuperado el 28 de Mayo de 2009. en, http://es.wikipedia.org/wiki/Libertad

Diccionario del castrismo cotidiano. Recuperado el 27 de Febrero de 2009, en www.cubanalisis.com/BIBLIOTECA $\% 20$ ON\%20LINE/DICCIONARIO $\% 20$ DEL $\%$ 20CASTRIS MO $\% 20$ COTIDIANO $\% 200 N \%$ 20LINE/F.htm

Engels, F. (2001). El origen de la familia: la propiedad privada y el estado. México: Editores Mexicanos Unidos. Págs. 44-73.

Eiré, A. (2009). Diario el País. El Comunismo manda para crear necesidades. Galicia, E. pág. 1. Recuperado el 17 de Agosto de 2009, en

www.elpais.com/articulo/Galicia/17/08/09.

Gruffat Carolina (2005): Educación y sociedad, Ministerio de Educación, Ciencia y Tecnología, de http://portal.educ.ar/noticias/educacion-y-sociedad/el-respeto-de-los-derechoshumanos/29/03/09/.

Intervenc. Sistémica y T. Familiar Esc. Vasco-Navarra y Sant-Pau de TF. El amor en la convivencia familiar. Recuperado el 28 de Mayo de 2009, en http://ptobal.wordpress.com/2008/03/25/elamor-en-la-convivencia-familiar/ 
Llanos Cifuentes, C. (2004) ¿Cómo se educa la libertad en la familia?. Instituto Mexicano de Doctrina Social Cristiana. Recuperado el 28 de Mayo de 2009, en http://imdosoc.org/plataforma/index.php?option=com_content\&task=view\&id=296\&Itemid $=52$

Maza Pereda, A. El amor, como valor en la familia. Recuperado el 28 de Mayo de 2009, en http://www.churchforum.org/amor-como-valor-familia.htm.

Sigüenza Efraín. (2004). Lecturas de educación en valores. Recuperado el 27 de Marzo de 2009. Origen de la ética. Pág 2. http://www.conesup.net/descargas/Valores3.pdf.

Vega Ascencio Anastasio (1995) Derechos Humanos y Educación. De; http://www.congreso.gob. pe/congresista/1995/avega/nota13.htm.

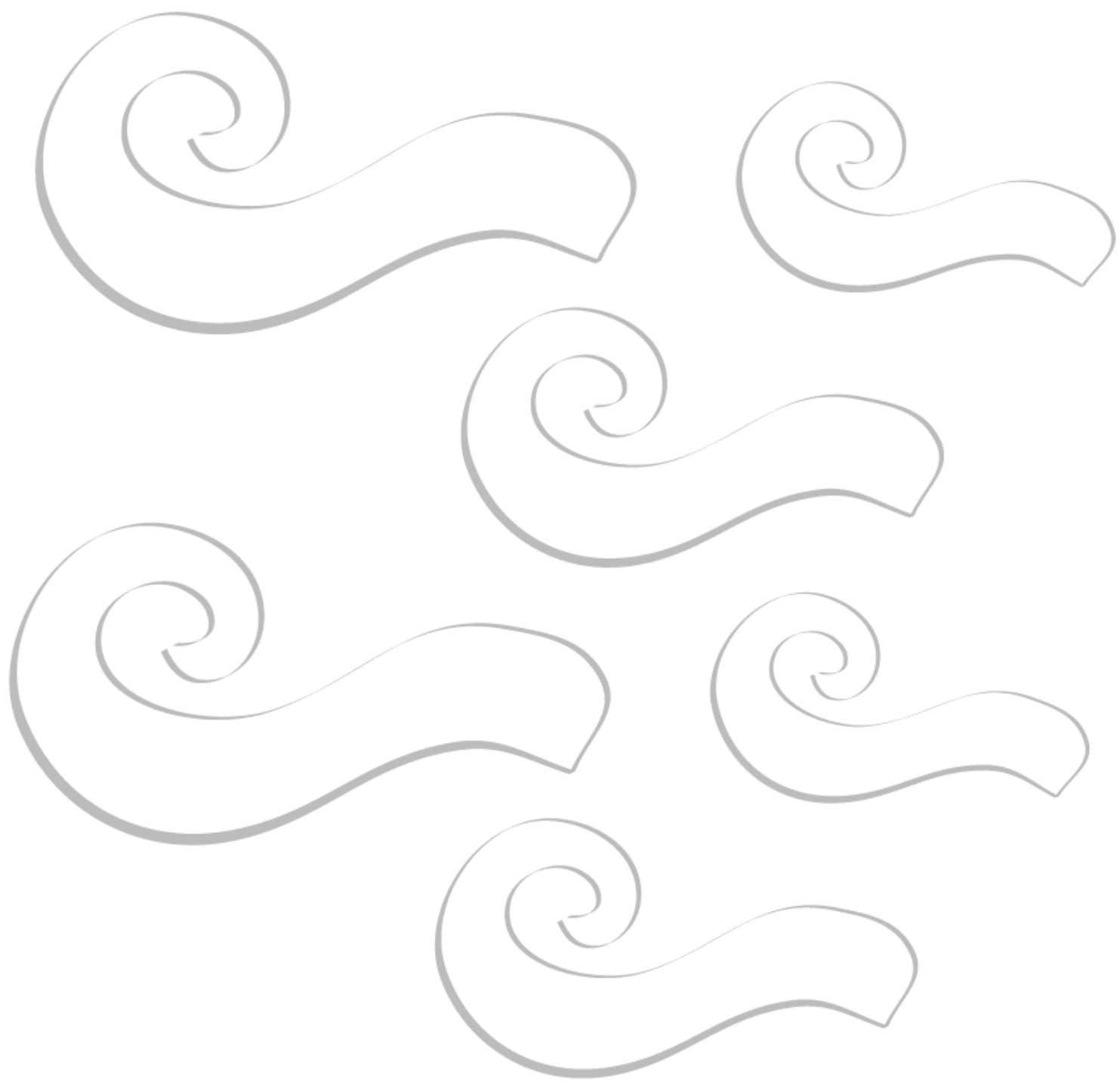

